\title{
Project Execution Plan Project 98L-EWW-460 Plutonium Stabilization and Handling (DOE\# 98-D-453)
}

Prepared for the U.S. Department of Energy

FLUOR DANHEL maNFORD, INc.

Richland, Washington 
HNF-4681

Revision 0

\section{Project Execution Plan Project 98L-EWW-460 \\ Plutonium Stabilization and Handling (DOE\# 98-D-453)}

Prepared by:

B\&W Hanford Company

Date Published

August 1999

Prepared for the U.S. Department of Energy

FWOR DANIEL HANFORD, INc.

Richland, Washington

Hanford Management and Integration Contractor for the

U.S. Department of Energy under Contract DE-AC06-96RL13200

Approved for Public Release; Further Dissemination Unlimited 
LEGAL DISCLAIMER

This report was prepared as an account of work sponsored by an agency of the United States Government. Neither the United States Government nor any agency thereof, nor any of their employees, nor any of their contractors, subcontractors or their employees, makes any warranty, express or implied, or assumes any legal liability or responsibility for the accuracy, completeness, or any third party's use or the results of such use of any information, apparatus, product, or process disclosed, or represents that its use would not infringe privately owned rights. Reference herein to any specific commercial product, process, or service by trade name, trademark, manufacturer, or otherwise, does not necessarily constitute or imply its endorsement. recommendation, or favoring by the United States Government or any agency thereof or its contractors or subcontractors. The views and opinions of authors expressed herein do not necessarily state or reflect those of the United States Government or any agency thereof.

This report has been reproduced from the best available copy.

Available in paper copy and microfiche.

Available to the U.S. Department of Energy and its contractors from U.S. Department of Energy

Office of Scientific and Technical Information (OST) P.O. Box 62

Oak Ridge, TN 37831

(615) $576-8401$

Available to the public from the U.S. Department of Commerce National Technical Information Service (NTIS)

5285 Port Royal Road

Springfield, VA 22161

(703) $487-4650$

Printed in the United States of America

DISCLM-1.CHP (8-95) 


\section{RELEASE AUTHORIZATION}

Document

Number:
HNF-4681, Rev. 0
Document

Title:
Project Execution Plan Project 98L-EWW-460 Plutonium

Stabilization and Handling (DOE number 98-D-453)

\section{This document, reviewed in accordance with DOE}

Order 241.1, "Scientific and Technical Information Management," and DOE G 241.1-1, "Guide to the Management of Scientific and Technical Information," does not contain classified or sensitive unclassified information and is:

\section{APPROVED FOR PUBLIC RELEASE}

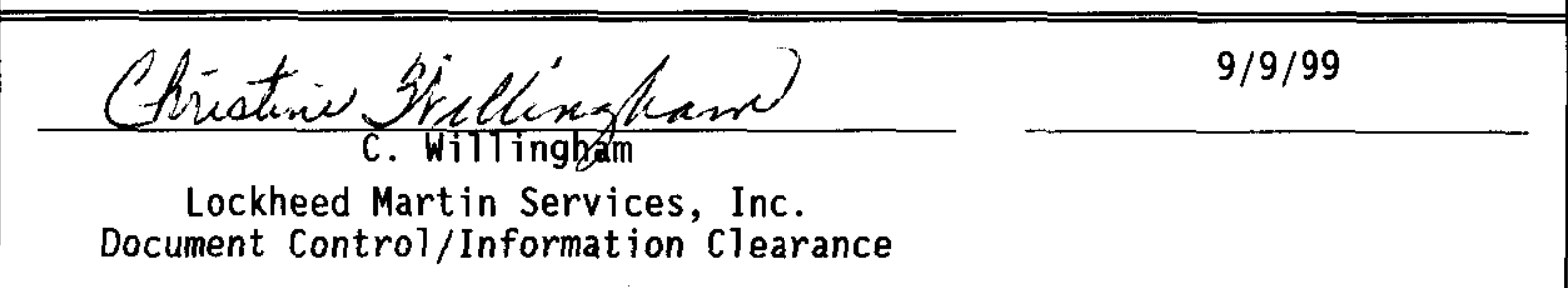

Reviewed for Applied Technology, Business Sensitive, Classified, Copyrighted, Export Controlled, Patent, Personal/Private, Proprietary, Protected CRADA, Trademark, Unclassified Control led Nuclear Information.

LEGAL DISCLAIMER. This report was prepared as an account of work sponsored by an agency of the United States Government. Neither the United States Government nor any agency thereof, not any of their employees, nor any of their contractors, subcontractors or their employees, makes any warranty, express or implied, or assumes any legal liability or responsibility for the accuracy, completeness, or any third party's use or the results of such use of any information, apparatus, product, or process disclosed, or represents that its use would not infringe privately owned rights. Reference herein to any specific commercial product, process, or service by trade nane, trademark, manufacturer, or otherwise, does not necessarily constitute or imply its endorsement, recommendation, or favoring by the United States Government or any agency thereof or its contractors or subcontractors. The views and opinions of authors expressed herein do not necessarily state or reflect those of the United States Government or any agency thereof. This report has been reproduced from the best available copy. Printed in the United States of America. 


\section{PROJECT EXECUTION PLAN}

\section{PROJECT 98L-EWW-460 \\ PLUTONIUM STABILIZATION AND HANDLING \\ (DOE\# 98-D-453)}

Prepared by

B\&W Hanford Company

for

U. S. Department of Energy

Richland Operations Office

Richland, Washington

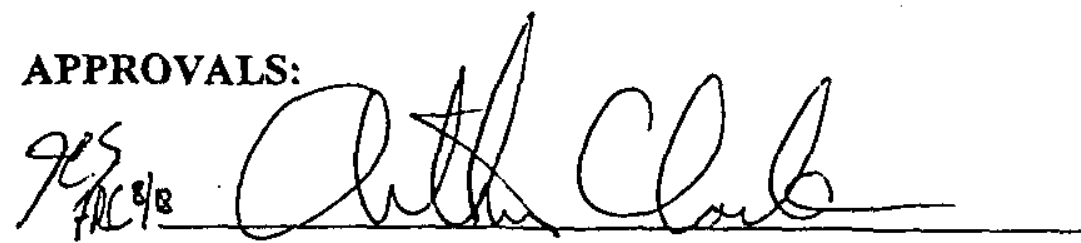

Arthur Clark

General Manager, B\&W Hanford Company (a) $8 / 19199$

L. J. Olguin.

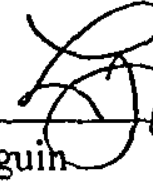

Project Birector, Fluor Daniel Hanford

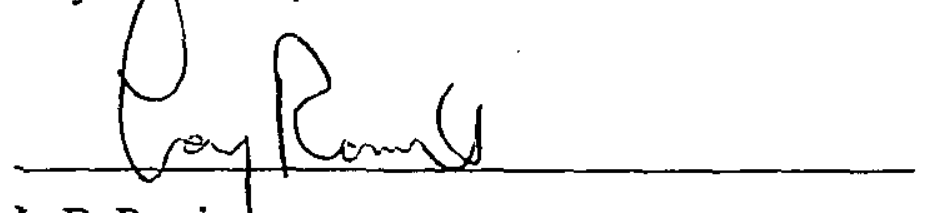

L. D. Romine

Director, Transition Projects Division

U.S. Department of Energy Richland Operations Office

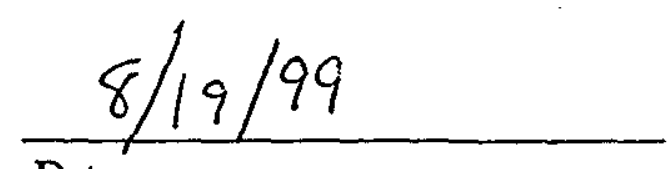

Date
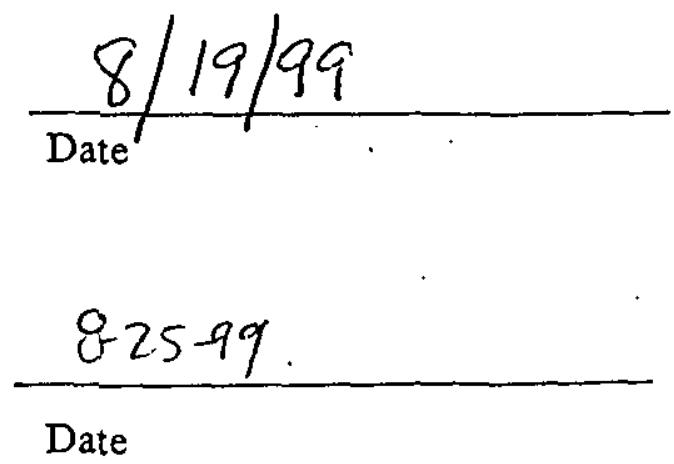

DOES NOT CONTAIA CLASSIFIED OR UINCLASSIFIED CONTROLLED NUCLEARWIOHEATIOA

\section{Reviowing}

Othaial / ADC:

Date

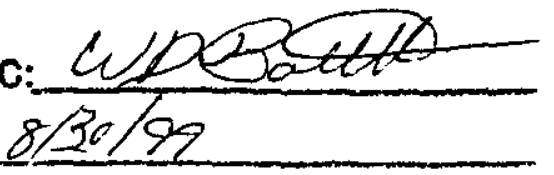


PROJECT EXECUTION PLAN

\begin{tabular}{|c|c|c|c|}
\hline & & & \\
\hline & & & \\
\hline & & & \\
\hline 0 & $8 / 17 / 99$ & Initial Issue - For Approval & JC Sinclair \\
\hline Revision & Date & Revision Description & Approved By \\
\hline
\end{tabular}




\section{Preface}

\section{Executive Summary}

\section{Purpose of the PEP}

This Project Execution Plan (PEP) describes the management methods and responsibilities of the project participants. Project W-460 is sufficiently large to warrant a stand alone PEP. This project specific PEP describes the relationships and responsibilities of the project team and identifies the technical, schedule, and cost baselines that have been established for the project.

The Department of Energy (DOE), Hanford Works (Hanford), at Richland Wa. currently does not have a system capable of stabilizing or packaging large quantities of plutonium-bearing solids to meet DOE technical standard DOE-STD-3013-96. This project will allow Hanford to meet this standard by installing stabilization and packaging equipment (SPE). The SPE is capable of stabilizing and packaging the current inventory of greater than 50 percent plutoniumbearing materials currently stored in the Plutonium Finishing Plant's (PFP) vaults into 3013 storage containers.

The scope of this project is to procure and install the SPE via a Hanford contract and coordination with the Savannah River Site. In addition, the project will modify PFP vaults and upgrade the PFP Laboratory measurement systems. The Facility infrastructure will be modified to support the new SPE system and the new standardized storage container configuration.

Use of this document is described in the Project Hanford Policy and Procedure System under HNF-PRO-1999, Construction Program Conceptual Phase. 


\section{TABLE OF CONTENTS}

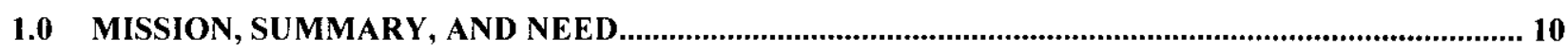

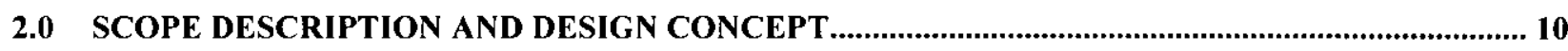

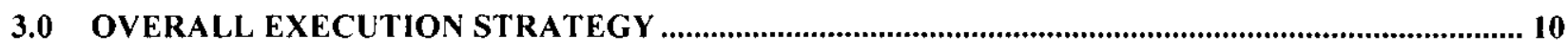

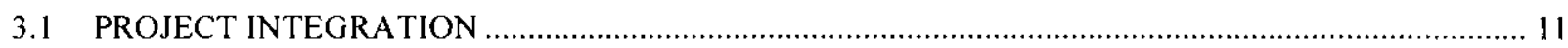

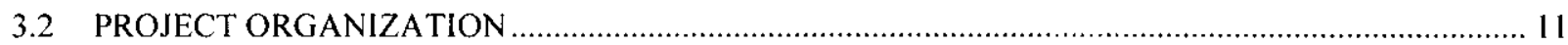

3.2.I U.S. Department of Energy Headquarters …….................................................................... 13

3.2.2 U.S. Department of Energy-Richland Operations Office …....................................................... 14

3.2.3 FDH - Project Hanford Management Contractor Responsibilities. ............................................ 15

3.2.4 BWHC - Facility Stabilization Project Performance Contractor ................................................ 16

3.2.5 FDNW - Architect-Engineer Construction/Construction Manager.......................................... 17

3.3 GENERAL FACILITY INTERFACE STRATEGY …................................................................... 18

4.0 PROCUREMENT AND CONTRACTING APPROACH ................................................................... 19

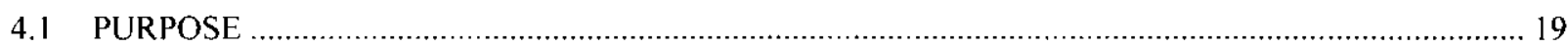

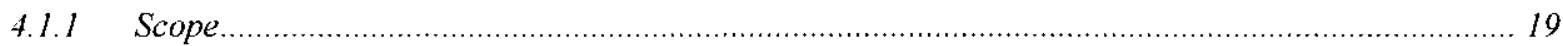

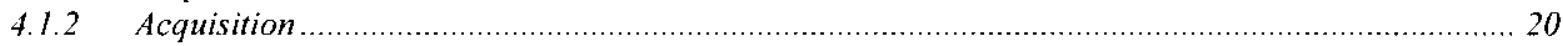

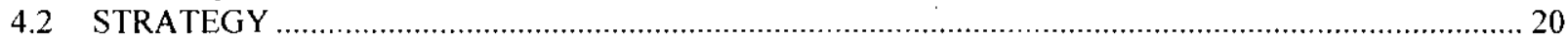

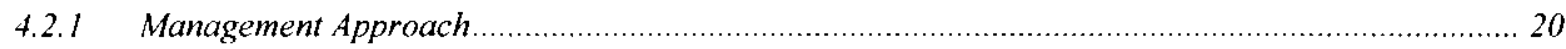

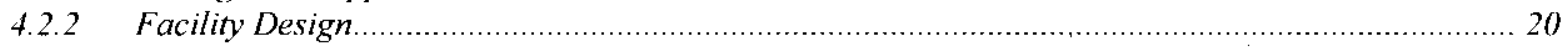

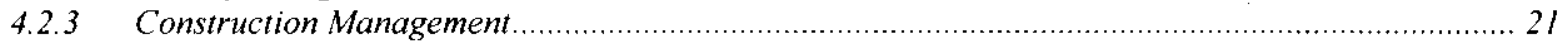

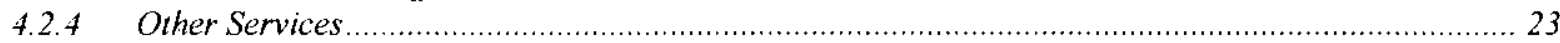

4.2.5 BTS and Westinghouse Savannah River Company .............................................................. 24

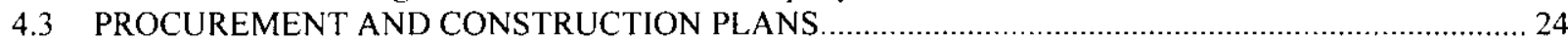

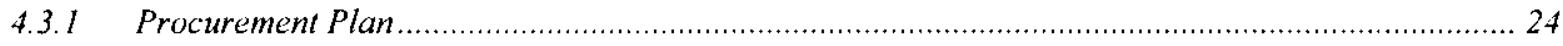

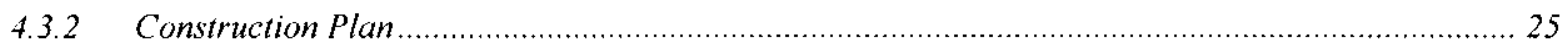

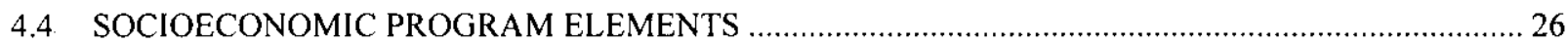

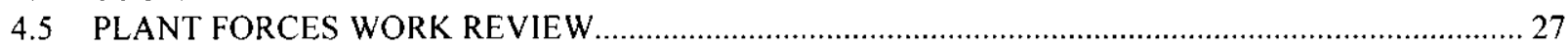

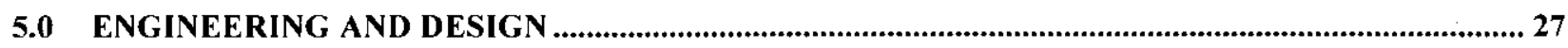

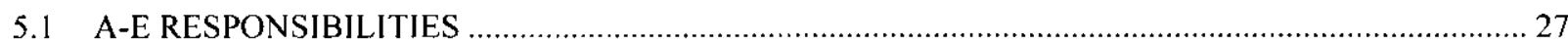

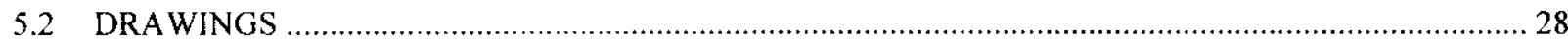

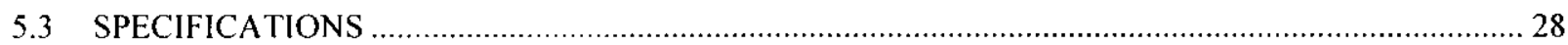

5.4 POLLUTION PREVENTION AND WASTE MINIMIZATION REQUIREMENTS …......................... 30

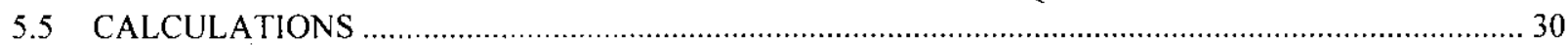

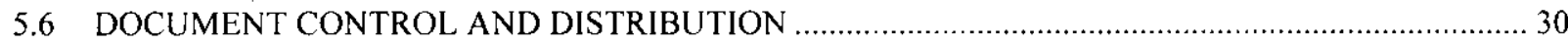

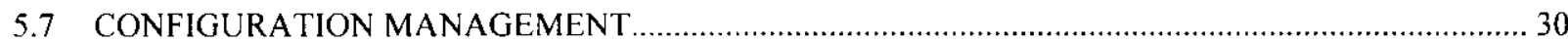

5.8 INTERFACE CONTROL WITH EXISTING SYSTEMS/FACILITIES ............................................. 30

5.9 ENGINEERING AND DESIGN PROJECT CONTROLS/CHANGE CONTROL ................................. 31

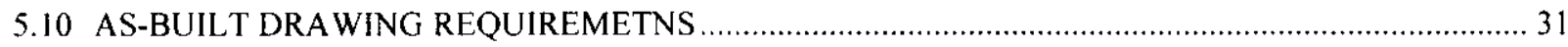

5.11 CONSTRUCTABILITY, OPERABILITY, AND MAINTAINABILITY REVIEW ….......................... 31

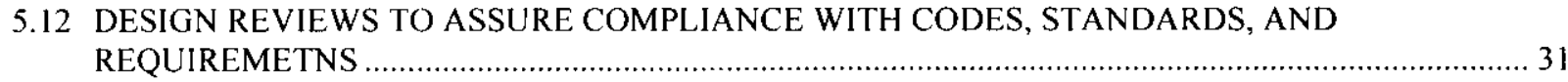

5.13 WALKDOWNS OF EXISTING FACILITIES/FIELD INVESTIGATIONS ........................................... 31

5.14 ALARA, LIFE-CYCLE APPROACH TO RADIATION DOSE, CONTAMINATION, AND

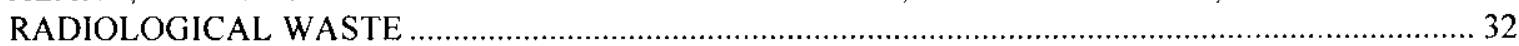

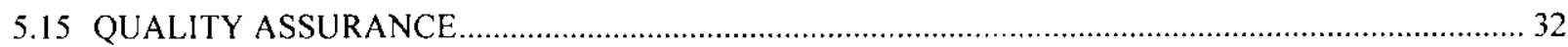

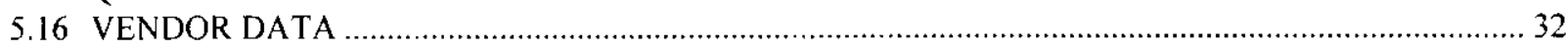

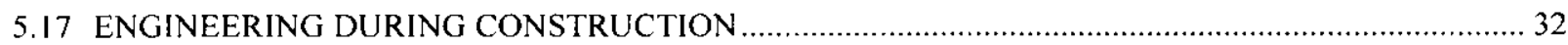

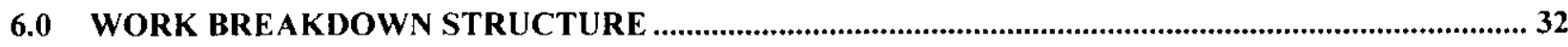


7.0 PERFORMANCE BASELINE DEFINITION \& CONTROL.................................................................... 33

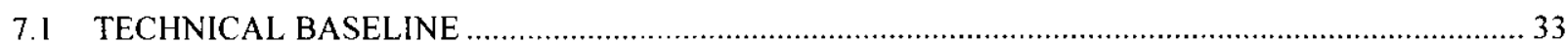

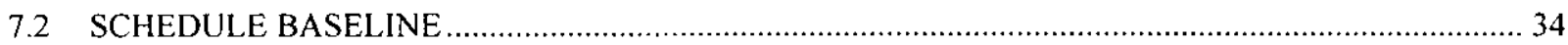

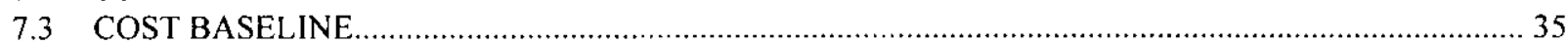

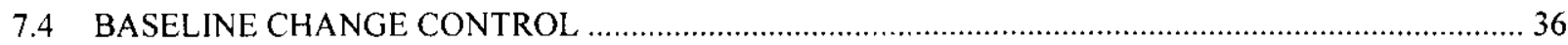

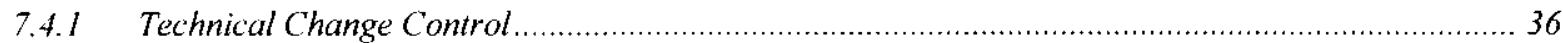

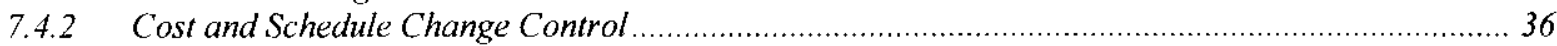

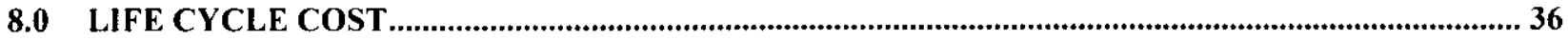

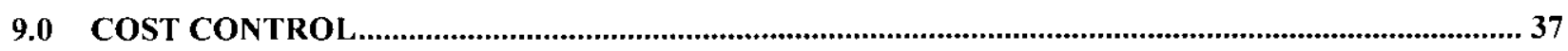

$10.0 \quad$ PROJECT (CONSTRUCTION) RISK

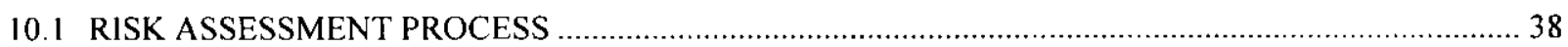

10.2 RISK ASSESSMENT FACTORS

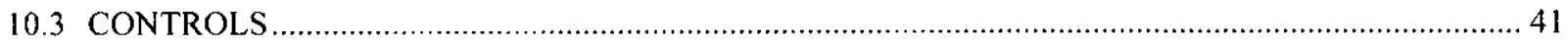

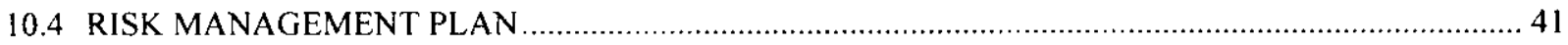

11.0 PERFORMANCE MEASUREMENT, REPORTING, AND FORECASTING ..................................... 41

12.0 FUNDING (STRATEGY TO ASSURE CONTINUITY OF FEDERAL FUNDING)_......................... 42

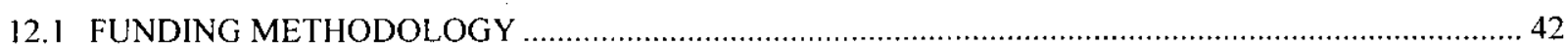

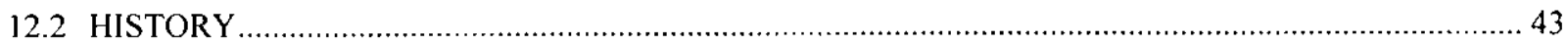

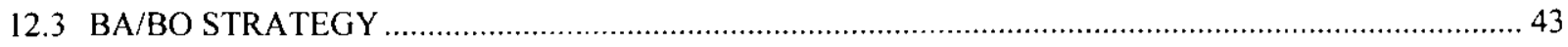

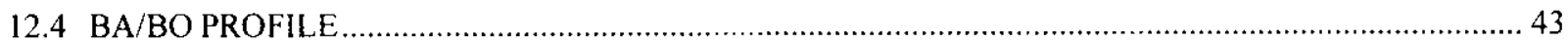

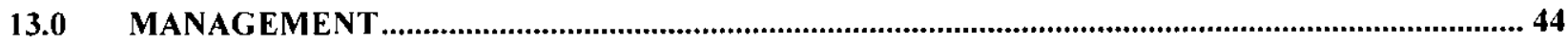

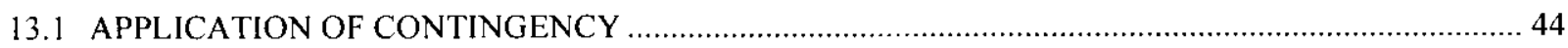

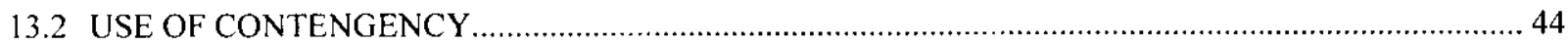

14.0 ENVIRONMENTAL, LICENSING, AND PERMITTING STRATEGY (NEPA, ETC.) .................... 45

15.0 INSPECTION, TEST, EVALUATION, TURNOVER/ACCEPTANCE, AND START-UP PLAN.... 46

15.1 CONSTRUCTION INSPECTION ORGANIZATION

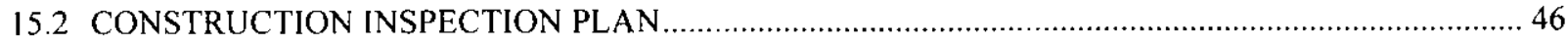

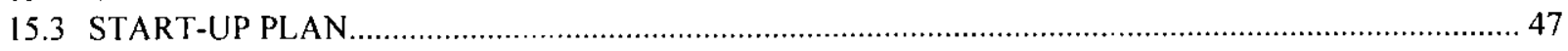

15.4 ACCEPTANCE INSPECTION (AI)

15.5 JURISDICTIONAL TURNOVER

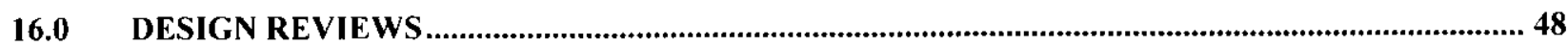

17.0 QUALITY ASSURANCE

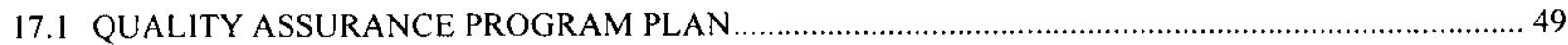

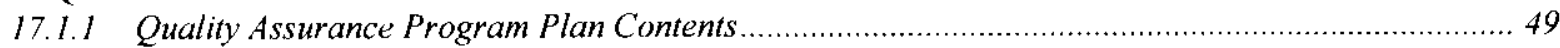

17.1.2 Quality Assurance Program Plan Application .................................................................... 50

17.2 APPLICABLE SAFETY CLASSIFICATION DETERMINATION .....................................................5 50

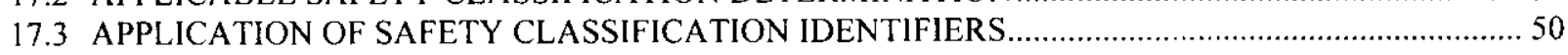

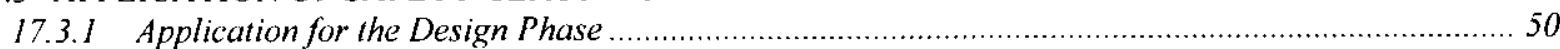

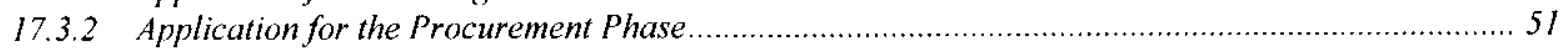

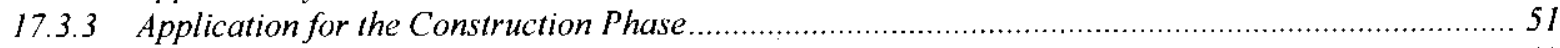

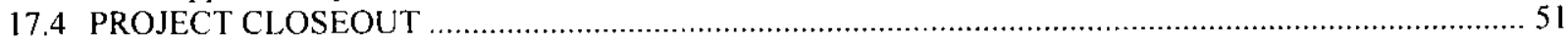

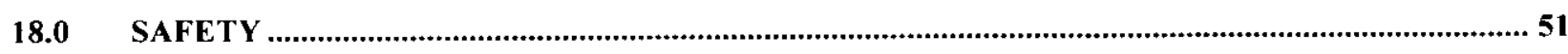

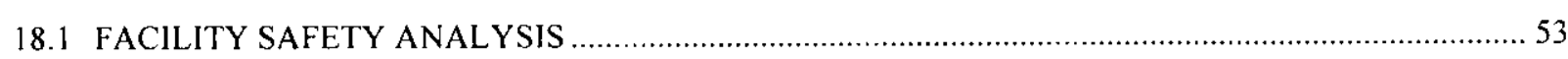




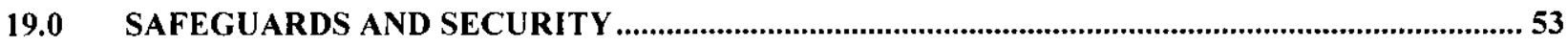

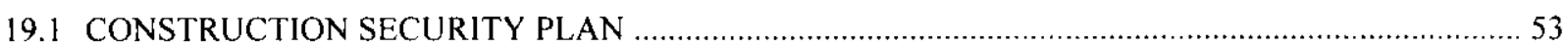

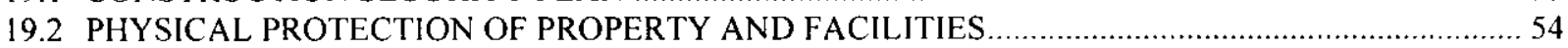

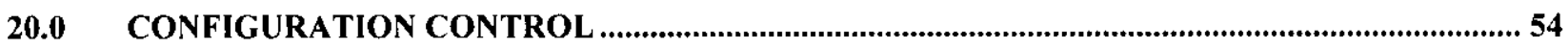

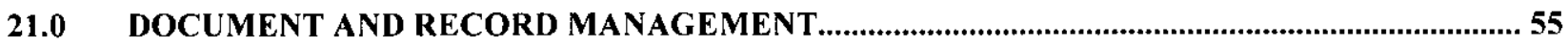

22.0 PROCEDURE/ PROCEDURE DEVELOPMENT ........................................................................... 55

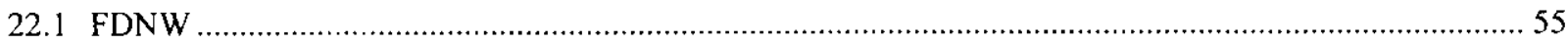

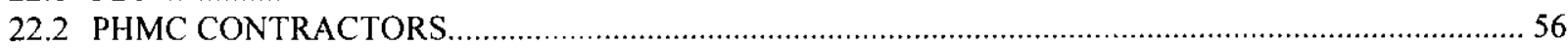

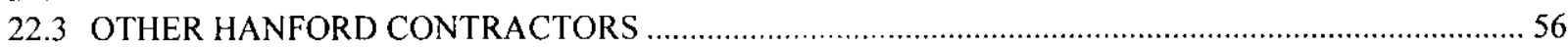

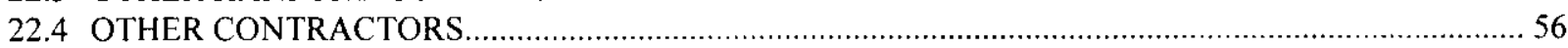

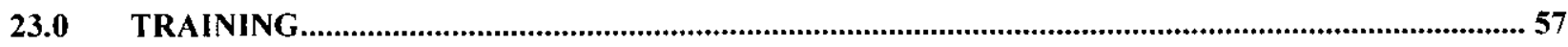

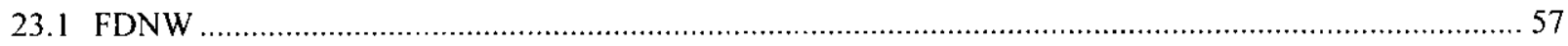

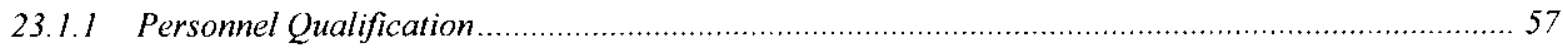

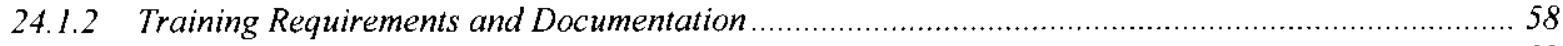

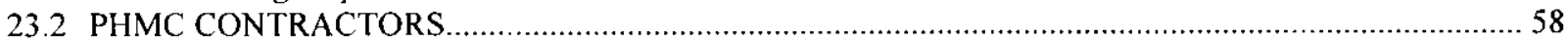

23.3 OTHER HANFORD CONTRACTORS

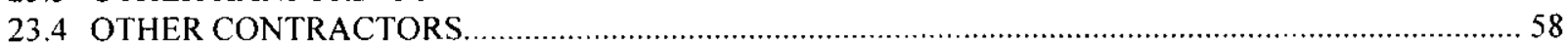

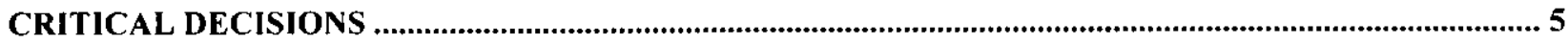


LIST OF FIGURE

Figure 3-1 - Project W-460 Functional Organization Chart

LIST OF TABLES

Table 3-1 - Project W-460 Activity Matrix

Table 4-1 - Project W-460 Summary of Significant Managing Contractor Furnished Equipment

Procurement Actions. 24

Table 4-2 - Project W-460 Summary of Significant Construction Program Activities 25

Table 4-3 - Project W-460 Summary of Significant Socioeconomic Program Procurement

Actions 26

Table 10-1 - Project W-460 Tabulation of Risk Contributors (Sample) 39

Table 14-1 - Summary of Potential Permits/Approvals Requirements 46

Table B-1 - BWHC Schedule Objectives 1

Table B-2 - Total Estimated Costs 3

\section{APPENDICES}

Appendix A, Project Schedule Appendix B, BWHC Schedule Objectives and Total Estimated Costs Appendix C, PuSh Project W-460 Organization Chart Appendix D, Memorandum of Understanding Between WSRC and BWHC Appendix E, BCR Path Forward Crosswalk Appendix F, Environmental Requirements Checklist Appendix G, BA/BO Profile 


\section{ACRONYMS}

\begin{tabular}{|c|c|}
\hline A-E & Architect-Engineer \\
\hline AECM & architect-engineer construction manager \\
\hline AI & acceptance inspection \\
\hline ALARA & as low as reasonably achievable \\
\hline $\mathrm{AMF}$ & Office of Assistant Manager for Facility Transition \\
\hline ATP & acceptance test procedures \\
\hline $\mathrm{BA} / \mathrm{BO}$ & Budget Authority/Budget Outlay \\
\hline BCR & Baseline Change Request \\
\hline BNF & British Nuclear Fuels Limited, Incorporated \\
\hline BTC & bagless transfer can \\
\hline BTS & bagless transfer system \\
\hline BWHC & B\&W Hanford Company \\
\hline $\mathrm{CCD}$ & Construction Completion Document \\
\hline $\mathrm{CD}$ & Criteria Document \\
\hline CDR & conceptual design report \\
\hline CENRTC & capital equipment not related to construction \\
\hline $\mathrm{CF}$ & construction forces \\
\hline CGI & commercial grade items \\
\hline $\mathrm{CM}$ & construction management \\
\hline $\mathrm{CO}$ & contracting officer \\
\hline COR & contracting officer's representative \\
\hline CPAF & Cost Plus Award Fee \\
\hline CPFF & Cost Plus Fixed Fee \\
\hline CPIF & Cost Plus Incentive Fee \\
\hline CR & change request \\
\hline CSI & Construction Specification Institute \\
\hline DESH & DE\&S Hanford, Inc. \\
\hline DNFSB & Defense Nuclear Facility Safety Board \\
\hline DOE & United States Department of Energy \\
\hline DOE-HQ & United States Department of Energy-Headquarters \\
\hline DOE-RL & United States Department of Energy-Richland Operations Office \\
\hline DOE-OAK & United States Department of Energy-Oakland Operations Office \\
\hline DYN & DynCorp \\
\hline EAC & estimate at completion \\
\hline ECN & Engineering Change Notice \\
\hline EIS & environmental impact statement \\
\hline $\mathrm{ENCO}$ & Enterprise Company \\
\hline EPA & U.S. Environmental Protection Agency \\
\hline FSAR & Final Safety Analysis Report \\
\hline FDC & functional design criteria \\
\hline $\mathrm{FDH}$ & Fluor Daniel Hanford Incorporated \\
\hline FDNW & Fluor Daniel Northwest Incorporated \\
\hline FP & fixed price \\
\hline FY & fiscal year \\
\hline HQ & Headquarters-DOE, Washington, D.C. \\
\hline IPMP & Integrated Project Management Plan \\
\hline IAEA & International Atomic Energy Agency \\
\hline IWO & (DOE) Interoffice Work Order \\
\hline $\mathrm{JCS}$ & Job Control System \\
\hline LANL & Los Alamos National Laboratory \\
\hline LCAM & Life Cycle Asset Management \\
\hline
\end{tabular}




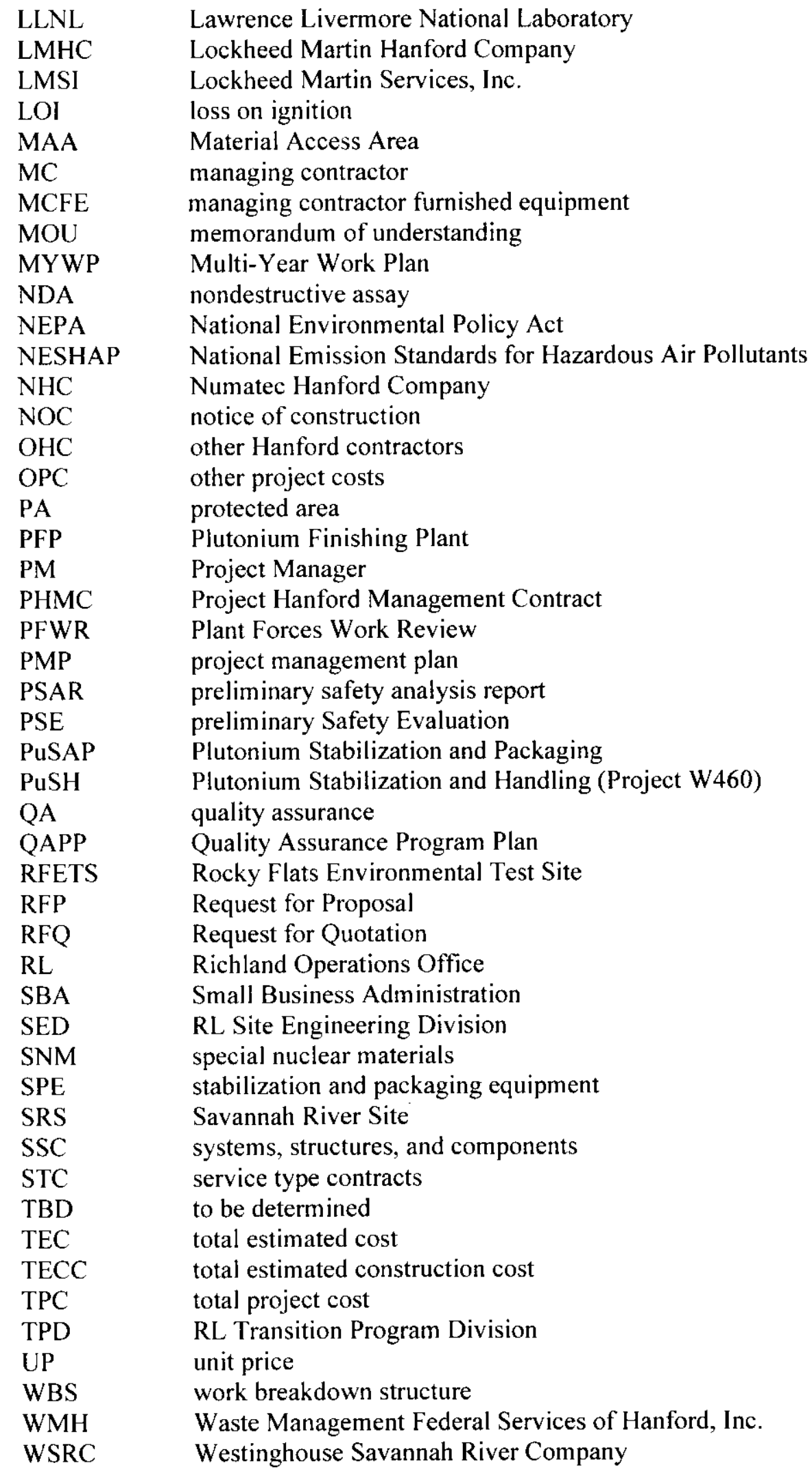




\subsection{MISSION, SUMMARY, AND NEED}

Project W-460 will provide the equipment and facility modifications necessary to stabilize and package plutonium-bearing special nuclear materials (SNM) that are currently stored in the Plutonium Finishing Plant (PFP) at the Hanford Site. The project will reduce risk to workers and the public by providing PFP a means to comply with current standards for the safe storage of plutonium bearing materials. For further details on Mission, Summary and Need see the current revision of the following documents: HNF-SD-W-460-FDC-001 (Functional Design Criteria (FDC)), HNF-SDW-460-CDR-001 (Conceptual Design Report(CDR)). For details on the Project background see FSP-4230 (PuSPS Alternative Review Support Data).

Some of the high level functional requirements the project will address are as follows:

- Added plutonium stabilization capability in the 2736-ZB facility.

- Ability to package the stabilized plutonium in a container set that is compliant with the DOE 3013 standard.

- Modifications as necessary to assure the current level of security risk is not increased.

- Modifications as necessary to the Nondestructive Assay Laboratory in 2736-ZB to accommodate the use of 3013 compliant containers.

- Additional office spaces for new and displaced operational staff in 2736-ZB resulting from the new stabilization and packaging operation.

The Project Functional Design Criteria (FDC) document provides the detailed technical requirements for the project.

\subsection{SCOPE DESCRIPTION AND DESIGN CONCEPT}

The basic technical objective of this project is to meet the requirements identified in the current revision of the FDC. The project W-460 preferred design concept, site location, and equipment are established in the current revision of the (CDR)..

\subsection{OVERALL EXECUTION STRATEGY}

The execution strategy for the project is described in this section. An organization chart (Figure 3-1) is provided that identifies the various participants and their reporting relationships, and an activity matrix (Table $3-1$ ) is provided that identifies the activities assigned to each participant. Functional responsibilities are shown, as appropriate. An organizational chart of the personnel currently assigned to support Project W-460 is shown in Appendix C. 


\subsection{PROJECT INTEGRATION}

The inner container packaging equipment(BTS) for Project W-460 will be coordinated through an inter-site task order between Richland Operations Office (RL) and the SRS field office and a Memorandum of Understanding between Fluor Daniel Hanford, Incorporated, (FDH) and the Westinghouse Savannah River Company (WSRC). Resources and activities for Project W-460 will be coordinated with other PFP stabilization and deactivation activities. Coordination is planned via the Integrated Project Management Plan (IPMP)(HNF-3617) for PFP, which is a planning document generated to coordinate PFP activities that lead toward stabilization and safe storage of remaining plutonium at the Hanford Site. Project W-460 will minimize interferences with the completion of other 94-1 PFP stabilization and deactivation activities and with safe maintenance of the PFP facility.

Project W-460 will be coordinated with any ongoing capital or expense projects within the PFP.

In addition to the usual domestic security considerations, international security will be considered for all aspects of Project W-460 via DOE contact with the IAEA.

\subsection{PROJECT ORGANIZATION}

Major participants in the project include DOE, U.S. Department of Energy-Richland Operations Office (DOE-RL), Project Hanford Management Contract (PHMC) team, and other on and offsite contractors. The project team members and their reporting relationships and functional responsibilities are shown Figure 3-1, Project W-460 Functional Organization Chart, and in Table 3-1, Project Activity Matrix.

The PHMC team prime contractor is FDH and is referred to as the managing contractor $(\mathrm{MC})$.

Contractual relations and responsibilities established between $\mathrm{RL}$ and the $\mathrm{MC}$ are identified in the DOE Contract DE-AC106-96RL13200. The RL approach for administering this contract is specified in the contract administration plan, Project Hanford Management Contract. This contract administration style entails partnering with the MC and its subcontractors to achieve mutually beneficial results.

The primary subcontractor for project W-460 is the Facility Stabilization Project performance subcontractor, BWHC. The BWHC Architect-Engineer/Construction Manager (AECM) subcontractor is FDNW.

The team is further enhanced by the appropriate FDH and BWHC onsite quality, safety, environmental, and health organizations employed to fulfill the project objectives in an efficient, quality, safe, secure, and environmentally responsive manner. 
Figure 3-1 - Project W-460 Functional Organization Chart

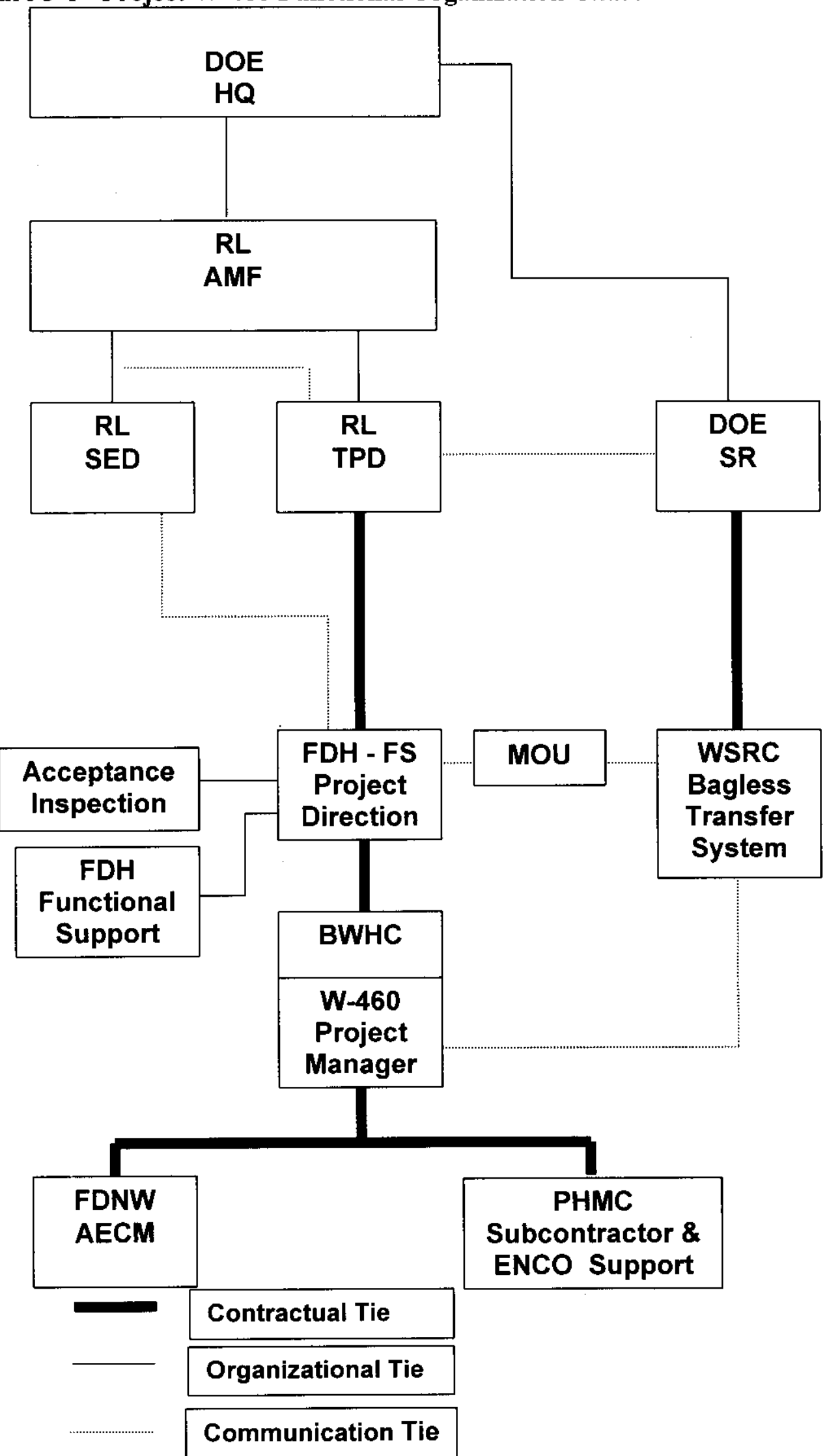


Table 3-1 - Project W-460 Activity Matrix

$\mathrm{A}=$ Approve $\mathrm{P}=$ Prepare/Perform $\mathrm{S}=$ Support $\mathrm{T}=$ Technical Support

\begin{tabular}{|c|c|c|c|c|c|}
\hline Project Activity & $\begin{array}{l}\text { DOE- } \\
\text { RL }\end{array}$ & SRS & FDH & BWHC & FDNW \\
\hline \multicolumn{6}{|l|}{ Stabilization System } \\
\hline Design Authority & & & & $\mathrm{P}$ & \\
\hline Design Ägent /Design Media & & & $\mathrm{A}$ & $\mathrm{A}$ & $\mathrm{P}$ \\
\hline Procurement & & & & $\mathrm{T}$ & $\mathrm{P}$ \\
\hline Acceptance Testing & & & A & $\mathrm{A}$ & $\mathrm{P}$ \\
\hline \multicolumn{6}{|l|}{ Inner Can Packaging Equipment } \\
\hline Design Authority & & & & $\mathrm{P}$ & \\
\hline Design Agent / Design Media & & $P$ & $\mathrm{~A}$ & $\mathrm{~A}$ & \\
\hline Procurement & $\mathrm{P}$ & & $\mathrm{T}$ & $T$ & \\
\hline Factory Testing & A & $\mathrm{P}$ & $\mathrm{A}$ & A & $\overline{\mathrm{S}}$ \\
\hline \multicolumn{6}{|l|}{ Outer Can Welding Equipment } \\
\hline Design Authority & & & & $\mathrm{P}$ & \\
\hline Design Agent / Design Media & & & $\mathrm{A}$ & $\mathrm{P}$ & $\mathrm{S}$ \\
\hline Procurement & & & & $\mathrm{P}$ & \\
\hline Acceptance Testing & & & $\mathrm{A}$ & A & $\mathrm{P}$ \\
\hline Procure 3013 Containers & $\mathrm{S}$ & $\mathrm{P}$ & & $\mathrm{P}$ & \\
\hline \multirow{2}{*}{\multicolumn{4}{|c|}{ Facility Modifications }} & & \\
\hline Design Authority & & & & $P$ & \\
\hline Design Agent & & & & & $P$ \\
\hline \multicolumn{6}{|l|}{ Facility Design Media } \\
\hline - Office Trailer Package & & & A & $\mathrm{A}$ & $\mathrm{P}$ \\
\hline - Vault Mod. Package & & & $\mathrm{A}$ & $\mathrm{A}$ & $\ddot{P}$ \\
\hline - Infrastructure Mod. Package & & & $\mathrm{A}$ & $\mathrm{A}$ & $\mathrm{P}$ \\
\hline Environmental Permitting & A & & $\mathrm{A}$ & $\mathrm{P}$ & $\mathrm{S}$ \\
\hline PSAR/FSAR & A & & $\mathrm{A}$ & $\mathrm{A}$ & $P$ \\
\hline Acceptance Inspection & & & $\mathrm{P}$ & & \\
\hline Engineering During Construction & & & & & $\mathrm{P}$ \\
\hline Procure Calorimeters & & & & $\mathrm{P}$ & $\mathrm{T}$ \\
\hline Procure Process Stack Monitor Sys. & & & & $\mathrm{P}$ & $\mathrm{T}$ \\
\hline Construction Management & & & & & $\mathbf{P}$ \\
\hline Acceptance Test Procedures & & & $\bar{A}$ & $\mathrm{~A}$ & $\mathrm{P}$ \\
\hline Operational Test Procedures & & & A & $\mathrm{P}$ & \\
\hline \multicolumn{6}{|l|}{ Project Management } \\
\hline W-460 Project Management & & & & $\vec{P}$ & \\
\hline Project Management Plan & $\mathrm{A}$ & & $\mathrm{A}$ & $\mathbf{P}$ & $\mathrm{S}$ \\
\hline Quality Assurance Program Plan & $\mathrm{A}$ & & $\mathrm{A}$ & $\mathrm{P}$ & $\mathrm{S}$ \\
\hline Cost Estimating & $\mathrm{A}$ & & $\bar{A}$ & $\mathrm{~A}$ & $P$ \\
\hline Integrated Project Schedule & $\mathrm{A}$ & & $\mathrm{A}$ & $\mathrm{P}$ & $\mathrm{S}$ \\
\hline Construction Completion Document & $\bar{A}$ & & $\mathrm{~A}$ & $\mathrm{P}$ & $\mathrm{S}$ \\
\hline Project Closeout & & & & $\mathrm{P}$ & $\mathrm{S}$ \\
\hline
\end{tabular}

\subsubsection{U.S. Department of Energy Headquarters}

DOE provides programmatic direction and overall surveillance of project performance through RL. The DOE responsibilities include: 
- Maintain an overview of project performance to ensure achievement of scope, cost, and schedule baselines through the project reporting system and periodic project review meetings, as required.

- Maintain an overview of project management execution.

- Ensure that all required DOE activities in support of the project are accomplished, as needed, including the assistance and guidance from other government offices.

\subsubsection{U.S. Department of Energy-Richland Operations Office}

The RL manager (or designee) is responsible for the definition, oversight, and acceptance of the work performed by the PHMC and its subcontractors. In addition, the RL Manager has authority for approval of the project Key and Critical Decisions that are formally delegated to RL by United States Department of EnergyHeadquarters (DOE-HQ).

In general terms, the role of $\mathrm{RL}$, with regard to administering the PHMC contract, is to:

- Define success criteria and values.

- Establish boundaries for integration.

- Set priorities.

- Establish strategic performance measures.

- Define outcomes and deliverables.

- Establish minimum site standards and evaluate the results.

- Provide technical oversight to ensure that the products and services, for which the $\mathrm{CO}$ and COR are responsible are delivered in accordance with the contract terms and conditions.

- Perform inspection and acceptance of work, as required. The contracting officer (CO) and contracting officer representative (COR) or other duly authorized Government representative will accomplish inspection of all products, reports, or services under the contract. The $\mathrm{CO}$ or other duly designated representative will accomplish acceptance of all work and effort under the PHMC contract. The COR does not have authority to accept nonconforming work or delete requirements of the contract.

- Review invoices as required.

- Conduct periodic reviews, audits, surveillance, and RL independent assessments of the $\mathrm{MC}$ and its subcontractors to ensure compliance with the terms of the contract and to ensure that the MC's administration of its subcontractors is effective.

- Provide approval of multi-year work plans (MYWPs). 
The RL Transition Program Division (TPD) will be responsible for the interface with DOE HQ and other federal agencies regarding the project interface with the IAEA. The funding for the project is also controlled through the RL-TPD.

The RL Site Engineering Division (SED) is responsible for the continuing oversite and program management for W-460.

\subsubsection{FDH - Project Hanford Management Contractor Responsibilities.}

FDH is responsible and accountable for management of all activities associated with Project W-460. The FDH role focuses on allocating resources, management, and integration of the work (what and when), while its subcontractors are responsible for operations (how the work is done). The MC role includes defining the work necessary to accomplish the objectives established by RL and working with RL to establish specific performance agreements tied to PHMC award fee objectives. FDH's responsibilities include the prime interface with RL. All contractual requirements and formal communications between the PHMC team and RL will be coordinated through the office of the FDH Facility Stabilization Project Director. The Facility Stabilization Project Director is responsible for integrating horizontally across major project boundaries and vertically to DOE and the major subcontractors (e.g., BWHC and DynCorp). This approach will ensure vertical definition of interfaces and requirements from FDH down through the major subcontractors and will provide horizontal integration of interfaces and requirements among major subcontractors.

Specific FDH responsibilities associated with the Project W-460 include the following:

- Allocating resources.

- Setting operational standards for subcontractors (minimum standards).

- Integrating project site wide activities, including coordinating with and participating in the PFP Deactivation Quartet and Hanford Transition Board of Directors.

- Evaluating effectiveness of subcontractors.

- Provides surveillance and overview of project execution to ensure compliance with DOE approved policies, directives, requirements, and standards.

- Transmitting to $\mathrm{RL}$, as required copies of the project documentation, including appropriate backup information.

- Approving all changes that affect the approved project baseline, including changes to the functional requirements, authorized budget, and the authorized schedule.

- Final approval of all construction activities utilizing the Acceptance Inspection Organization 


\subsubsection{BWHC - Facility Stabilization Project Performance Contractor}

As the performing contractor, BWHC is responsible for technical direction and management of the project and for ensuring that the project is completed in accordance with the approved project baseline. BWHC responsibilities include:

- Approving the definitive design (drawings and specifications) for compliance with the functional requirements as the PFP design authority and functioning as the end user organization.

- Providing project management services to control the following:

- Project technical baseline.

- Integrated project baseline schedule.

- Total project cost (TPC) baseline.

- AECM subcontract.

- Interface with the other PHMC Subcontractors for services as needed.

- Providing technical input to support the SPE procurement.

- Providing facility support and integration of ongoing PFP operations with the project.

- Developing the facility procedures and training needed to support implementation of Project W-460.

- Transmitting copies of the project documentation, as required, including appropriate backup information to FDH.

- Coordinating reviews with FDH and serving as a single point-of-contact for such reviews.

- Providing the administration of overall project baseline change control to assure appropriate management of scope, cost, and schedule commitments through the change control process, as stipulated in Element 9.0 of this PEP. Approving all baseline changes.

- Coordinating development of safety analyses, authorization basis amendments, NEPA documentation, permits, and other related documentation in support of Project W-460.

- Assuring that the project's function and funding are programmatically integrated into the PFP, Hanford Site, and DOE Complex plans.

- Providing contractual direction to the Design Agent for the performance of design, procurement, and construction. Providing to the Design Agent the project technical baseline and safety basis for design.

- Ensuring project participants establish and implement the appropriate quality assurance procedures, compatible with DOE and RL requirements.

- Ensuring that quality-affecting records comply with governing requirements, which provide objective evidence for Project W-460 design, procurement, and construction activities, are maintained. Documentation and records that provide a 
traceable project history are properly dispositioned for archive at project completion.

- Project compliance with quality requirements during the performance of a project is the responsibility of the performing project organization. BWHC will ensure project participants establish and implement the appropriate quality assurance procedures, compatible with DOE and RL requirements. A project specific Quality Assurance Program Plan, HNF-SD-W460-QAPP-001, documents the Project W-460 approach for accomplishing quality objectives.

- Providing requested information to FDH and DOE-RL

- Taking corrective actions when required

\subsubsection{FDNW - Architect-Engineer Construction/Construction Manager}

BWHC will contract FDNW to provide Architect-Engineer (A-E) and Construction Management (CM) services for the performance of Project W-460.

\subsubsection{Architect-Engineer}

BWHC will contract FDNW to provide A-E services to prepare definitive design for Project W-460. FDNW A-E responsibilities will include:

- Project Management services to:

- Provide a single point-of-responsibility for the day-to-day management of the A-E work scope.

- Ensure appropriate management of the A-E scope, cost, and schedule commitments through application of the FDNW change control practice.

- Provide status reports to BWHC in accordance with the BWHC contractual requirements.

- Provide design services to ensure that established project quality objectives and functional design requirements are satisfied.

- Assure that the design meets the applicable codes, standards, requirements, regulations, and DOE directives.

- Provide constructibility reviews of the design.

- Provide engineering in support of construction, including submittal reviews, design changes, nonconformance report disposition, requisitions for safety class material, support of acceptance testing, and as-built drawings of the design.

- Maintain complete A-E project design files by FDNW practices.

- Provide estimating and scheduling services to support ongoing project needs. 


\subsubsection{Construction/Construction Management}

BWHC will contract FDNW to provide C/CM services for project W-460. This will include the management of both onsite construction forces and fixed-price construction with offsite contractors. FDNW C/CM responsibilities include project management services to:

- Provide a single point of responsibility for the day-to-day management of the CM work scope.

- Ensure appropriate management of the CM scope, cost, and schedule commitments through application of the FDNW change control practices.

- Provide status reports to BWHC in accordance with the BWHC contractual requirements. .

- Provide onsite construction management services including quality assurance, quality control, safety review, environmental compliance, scheduling, estimating, and cost control during construction.

- Administer fixed price contracts.

- Provide orientation for construction subcontractors and Small Business Administration (SBA) [8(a)] construction contractors.

- Provide direct supervision and quality control of construction forces.

- Provide procurement services as related to construction.

- Provide fair cost estimates and maintain complete files on the construction procedures and construction schedules.

- Provide construction site safety inspections and surveillance.

- Ensure that construction activities are performed in a quality manner and in accordance with requirements and governing procedures.

\subsection{GENERAL FACILITY INTERFACE STRATEGY}

The key to the successful implementation of Project W-460 at an operating nuclear facility will be the active participation of PFP plant personnel in the project development and execution. Good communications between the project and the Plant will assure that the needs of both will be addressed. In general, the areas of interface that will assure that the project and plant are in sync are as follows:

- Planning - The W-460 project schedule and cost information will roll up in to the MYWP. This integration will assure that the interface with other ongoing PFP activities and projects are coordinated and that plant resources needed to support the project are available when needed. This will also assure that project funding needs are clearly identified and coordinated with the overall plant budget. 
- Design - PFP Facility personnel will be the Design Authority for the project. As such, they will establish the technical requirements for the project via the FDC and review and approve all design media to assure compliance with these

requirements. A wide cross-section of PFP organizations participates in the review and approval of both the conceptual and detailed designs.

- Procurement - PFP will perform procurement of Managing Contractor Furnished Equipment (MCFE) where the technical expertise for this procurement resides with plant personnel. This will apply to procurement of calorimeters, radiography equipment, stack monitoring equipment, outer can welding equipment, and 3013 storage containers.

- Construction - Project construction activities at PFP will be performed in accordance with approved work control packages. This process assures that all appropriate plant reviews have been performed on the work scope and that the plant has been properly configured to support the construction activity.

- Testing and Acceptance - Plant personnel will fully participate in the final testing and acceptance of installed project systems, structures, and components.

\subsection{PROCUREMENT AND CONTRACTING APPROACH}

\subsection{PURPOSE}

The purpose of Element 4.0 is to provide procurement and acquisition strategy for construction of Project W-460, Plutonium Stabilization and Handling. The section describes the steps necessary to implement this procurement and acquisition strategy and enable the project to procure equipment and construction contracts for the ordered and timely construction of the facility modifications.

\subsubsection{Scope}

All project organizations (as defined in Element 3) performing work that relates to procurement and construction package development will follow the provisions of this plan, and/or documents referred to herein as being appropriate guidance, for the procurement of capital equipment, material, design, support, and construction contracts or services.

This section provides site specific requirements and guidelines to $\mathrm{CM}$ for the project and supplies the implementation details to the A-E for construction and procurement packaging development.

On-Site CM will solicit competitive sealed bid proposals for all material procurement and contract work in accordance with guidelines and contract requirements. All contracting tools will be considered in preparing construction package documents to ensure maximum protection of project cost and schedule, including the use of direct- 
hire craft, where appropriate. Selection of the correct type of contract will also be of prime importance.

\subsubsection{Acquisition}

Services will be procured by methods, in accordance with federal regulations, that will best serve the project with proper consideration given to factors such as price, performance, and completion time.

Procurements should be to the advantage of the project and consider price, quality, and other factors. In order to award business on an impartial basis, Procurement will encourage full and free competition consistent with established industry standard business practices in securing the required services.

\subsection{STRATEGY}

\subsubsection{Management Approach}

The management approach, relationships, and major interfaces are detailed in Element 3.0 of this PEP.

The Facility Stabilization Project Performance Contractor, BWHC as the performing contractor under the PHMC, has established a project team to accomplish its work on this project in an expeditious and cost-effective manner with appropriate attention to quality and safety

The BWHC, in its capacity as the performing contractor, is responsible for and supports the PHMC by supplying technical direction, project management, control, integration, quality assurance (QA), applied technology, safety/regulatory compliance support, and startup and operations activities. The BWHC manages and integrates the A-E, technology, CM, and PFP support organizations. The BWHC will supply technical and site specific requirements to Westinghouse Savannah River Company (WSRC) during the design, fabrication and delivery of the bagless transfer system,

The work performed by each participant will be coordinated, guided, and technically monitored for compliance to the requirements by BWHC as the performing contractor.

\subsubsection{Facility Design}

The equipment(non-MCFE) and facility modifications will be procured and constructed in accordance with design documents provided by the current A-E (FDNW). Specifications and approved-for-construction drawings will provide the content and format necessary to complete construction, provide acceptance criteria, and support facility startup that conforms to design criteria and operational 
requirements. Design packages will be assembled to support the procurement and construction packages.

Select specialty (engineered equipment) designs and procurement specifications will be developed by subject expert design teams to obtain advantage of the latest technology while ensuring fit, form, and function philosophy and economies. Specific engineered equipment examples:

- Stack Monitoring Equipment

- NDA Radiography Equipment

- NDA Calorimeter Equipment

- Inner Can (3013) Packaging Equipment

- Outer Can (3013) Welding Equipment

\subsubsection{Construction Management}

FDNW, in accordance with the exclusivity clauses of the prime PHMC contract, will assign a Construction Manager who will be responsible for all construction management activities. FDNW will also be responsible for support to BWHC for the integration of construction baseline management into the project baseline management system. The project manager and the construction manager will utilize assigned project staff, interfacing organizations, support service groups, and matrixed project management organizations within FDNW to ensure a timely and economical execution of construction activities.

\subsubsection{Construction Strategy}

Fixed-Price Contractors: It is the intent of this plan to solicit competitive bids for the those parts of the construction work, in the judgement of the project team, that can support the performance and security risk of a fixed-price contract. The project team will utilize experienced personnel to prepare bid packages, perform market research to support the packages, advertise to obtain the maximum market exposure, and solicit and analyze the submitted contractor bids. The Hanford area, through approximately 20 years of contracting, has developed a base of small- to medium-sized contracting entities to support the basic site development contracts expected early in the project construction phases.

Construction Forces (CF): The project may utilize direct-hire construction craft, an assortment of construction equipment, and experienced supervision to perform construction activities. This direct-hire Construction Forces(CF) will be used when construction scope is ill-defined, when radiological or hazardous waste zones are encountered, when poor workmanship or inadequate performance by a fixed-price contractor necessitates action, when security is a consideration, when facility hot tieins are required, or for any activity the project team deems is in the best interest of the project. The work associated with the 2736-ZB and $2736-\mathrm{Z}$ buildings are included in this category. 


\subsubsection{Constructibility}

The intent of FDNW is to integrate construction knowledge and experience early during project engineering and planning to achieve overall project objectives. To achieve this, the following tasks are performed:

\section{$\underline{\text { Review All Design Documents }}$}

This is accomplished by reviewing the design as it progresses, as well as by performing formal reviews of the completed documents. It also includes reviews of cost estimates and schedules prepared by the A-E.

Resolution of Technical and Program Issues

Participate in resolution of project issues by providing recommendations on alternate construction methods and materials, preferred technical language for fixed-price specifications, and alternate performance methods to achieve the project schedule.

\section{Develop Construction Methods}

Provide the project team with the preferred methods of construction that will meet the project requirements in the most cost- and schedule-effective manner. This is accomplished by involving Construction Services in the evolution of the design to encourage incorporation of the most cost-effective methods prior to release of the design review packages.

\section{Provide Specific Hanford Site Construction Requirements}

This task is accomplished by experienced Construction Services personnel providing specific Hanford requirements and practices to the project team in the early design development. Examples include equipment access requirements, local labor practices, common materials of construction used at Hanford, and fixed-price contracting requirements.

\subsubsection{Pre-procurement Planning}

Pre-procurement planning is part of project team activities initiated during the Conceptual Design phase of the Project. The purpose of the preplanning effort is to analyze design-base documentation as it matures and to identify elements of equipment, material, and specialty fabrications that would be a candidate for early procurement actions. One of the criteria used in determining long-lead procurement action(s) is management of risk during construction. This is accomplished by facilitating the orderly delivery to the site of equipment, material, or specialty fabrication to support contract performance, construction sequence, and/or installation activities. (Note: No pre-procurement plan was developed for this project.) Advanced procurement actions identified in planning analysis are summarized in Table 4-1. The procurement actions listed in this element will assist the project design team in identifying and preparing required procurement specification documentation during detailed design. Methods for source qualification and fulfillment of quality control requirements are outlined in Element 18. 


\subsubsection{Construction Preplanning}

In order to be effective from a schedule and economic sense, the construction of the facility modification were organized into construction packages during early design phase. From these activities, each construction element will be analyzed to identify construction package definitions that will promote ease of construction; minimize the risk to the project from a budget, schedule, and resource utilization standpoint; and obtain the earliest possible startup of the facility. Construction packaging is developed not only to facilitate the construction sequence of events, but as a communication tool to the design team for identifying and organizing contract package design supporting documentation and interface points.

\subsubsection{Construction Interface Control}

Key to the successful execution of contract actions is the management and control of interface points between preceding, succeeding, and any overlapping contract activity. Clear definition of duties, relationships, responsibilities, field and shop work locations, material lay-down areas, power, water, site and survey monument maintenance, security, safety, and administrative access to and from work location, etc., needs to be succinctly addressed in the contract documents (including design media). In addition to the above contract administrative concerns, the construction package definition must consider the construction sequence to facilitate orderly contract changeover, startup support, and/or overlap and maintenance of design integrity and product quality. These contract interface points must be communicated to the design team and clearly distinguished as "left as" and/or "contract interface point" on the design documents.

\subsubsection{Other Services}

Service Type Contracts (STC): As a specific expertise is needed, BWHC may augment a core team competency with the judicious use of service contracts. Existing examples of service type contracts are:

- Project Dose Assessment by GTI

- Project Fire Hazard Analysis by Hughes and Associates

- NEPA and Notice of Construction by Waste Management Hanford Company

- Others as needed

DOE Interoffice Work Order (IWO): A IWO is a vehicle used to obtain services, expertise and/or equipment from another DOE complex contractor. The project will utilize IWO's for specific equipment. Specific examples are:

- Bagless Technology from SRS

- Calorimeter form LANL 


\subsubsection{BTS and Westinghouse Savannah River Company}

Through the use of a IWO, a brief scope statement and transfer funds from DOE-RL, DOE-SRS has agreed to supply as GFE the BTS in a Hanford glovebox. WSRC will perform the BTS work for SRS. BWHC will assist the RL on the BTS development, fabrication and delivery management through use of a Memorandum of Understanding (MOU) (refer to Appendix D) between WSRC and BWHC. No formal acquisition relationship exists between WSRC and BWHC other than the MOU. The MOU will form the basis for the business and technical administration of the BTS delivery between the two sites. Due to expediency and cost considerations, this approach was determined in the best interest to the government.

\subsection{PROCUREMENT AND CONSTRUCTION PLANS}

\subsubsection{Procurement Plan}

The project team will procure equipment, long-lead materials, and construction supplies and aids necessary to perform construction work. The team will also procure equipment, long-lead materials, and construction supplies and aids for maintenance activities on the construction site, site project administrative facilities and yard, and on an emergency basis, which will protect the integrity of in-place work (such as an emergency action between contract phases).

Table 4-1 defines equipment and materials that will be procured by the team and provided to the installation contractor as MCFE.

\section{Table 4-1 - Project W-460 Summary of Significant Managing Contractor Furnished Equipment Procurement Actions}

\begin{tabular}{|c|c|c|c|c|}
\hline $\begin{array}{l}\text { Procurement } \\
\text { Description }\end{array}$ & $\begin{array}{l}\text { Procurement } \\
\text { By }\end{array}$ & $\begin{array}{l}\text { Performance } \\
\text { Method }\end{array}$ & Vendor & Comments \\
\hline Calorimetry Units & BWHC & IWO & I.ANL & Two calorimetry units for the NDA lab \\
\hline Radiography Unit & BWHC & IWO or RFP & TBD & A radiography unit for the NDA Lab \\
\hline $\begin{array}{l}\text { BTS } \\
\text { (Inner Can Weld } \\
\text { Equipment) }\end{array}$ & $\mathrm{FIH} / \mathrm{BWWH}$ & IWO & SRS/WSRC & $\begin{array}{l}\text { WSRC to supply Bagless system installed in BWHC supplied } \\
\text { glovebox }\end{array}$ \\
\hline Bagless Glovebox & BWHC & $\begin{array}{l}\text { N/A } \\
\text { OR }\end{array}$ & Existing & $\begin{array}{l}\text { Use existing 'excess' glovebox from Hanford, ship to Savannah } \\
\text { River Site (WSRC) }\end{array}$ \\
\hline Bagless Transfer Inner & BWHC & IWO & SRS/WSRC & Full and half height inner cans \\
\hline 3013 Outer Cans & $\mathrm{BWHC} / \mathrm{RL}$ & TBD & TBD & TBD Outer 3013 Cans (may use Rocky Flats to obtain cans) \\
\hline Office Trailers & BWHC & N/A & Dyncorp & $\begin{array}{l}\text { Project will use two existing trailers at Hanford and have them } \\
\text { moved to PFP }\end{array}$ \\
\hline Change Trailer & FDNW & FP & TBD & $\begin{array}{l}\text { A small change trailer to be supplied as GFE to the fixed-price } \\
\text { contractor. }\end{array}$ \\
\hline $\begin{array}{l}\text { NESHAP Compliant } \\
\text { Exhaust Stack Monitor }\end{array}$ & BWHC & $\mathrm{RFP}$ & TBD & $\begin{array}{l}\text { The stack monitoring system for the new process exhaust for } \\
2736-7 . B \text {. }\end{array}$ \\
\hline $\begin{array}{l}\text { Remote Can Handling } \\
\text { Equipment }\end{array}$ & FDNW & RFP & TBD & $\begin{array}{l}\text { This includes any specialized remote handling equipment for } \\
3013 \text { Cans that will be needed for the NDA Lab or Vaults. }\end{array}$ \\
\hline $\begin{array}{l}\text { Outer Can Weld } \\
\text { System }\end{array}$ & BWHC & RFP & TBD & $\begin{array}{l}\text { An outer can weld system will be specified and procured by } \\
\text { BWHC with technical assistance from BWXT. }\end{array}$ \\
\hline
\end{tabular}


Installation/erection contractor (FDNW-CM) will supply all specialty materials, standard commercial grade materials, and standard commercial equipment not specified as MCFE. The project team will identify and set aside procurements and/or services for socioeconomic programs for small businesses and small disadvantaged businesses.

\subsubsection{Construction Plan}

Construction of the facility modifications will be accomplished by construction subcontracts and CF crews (direct hire). The Construction Plan, Table 4-2, sets forth the summary schedule of construction packages and construction subcontracts that have been identified. The type of construction subcontract method of performance used is based on the criteria used for selecting the most cost-effective method for completion of the construction package effort with reasonable market research to obtain a technically qualified, responsive proposal. As conditions warrant, the project team may revise a contract method of performance. The PEP will be revised as required to document the current subcontract methods and construction package definition.

The AECM on site contractor (FDNW) will procure following equipment in support of the construction plan:

- FDNW will procure a change trailer to be used in conjunction with two-excessed office trailers to be used to make the office trailer complex to support packaging and handling operations in 2736-ZB.

- FDNW will procure mechanized equipment for the remote handling and transport of the DOE Standard 3013 containers.

- All other material and equipment procurements associated with W-460 will be the responsibility of the construction contractor.

Table 4-2 - Project W-460 Summary of Significant Construction Program Activities

\begin{tabular}{|c|c|c|c|c|}
\hline $\begin{array}{c}\text { Contract } \\
\text { Description }\end{array}$ & $\begin{array}{c}\text { Contract } \\
\text { Administration }\end{array}$ & $\begin{array}{l}\text { Performance } \\
\text { Method }\end{array}$ & $\begin{array}{c}\text { Contract } \\
\text { Performed By }\end{array}$ & Comments \\
\hline $\begin{array}{l}\text { Design-Definitive Design } \\
\text { for Facility Modifications }\end{array}$ & $\begin{array}{l}\text { BWHC } \\
\text { (Design Authority) }\end{array}$ & CPFF & $\begin{array}{l}\text { FDNW } \\
\text { (Design Agent) }\end{array}$ & $\begin{array}{l}\text { Includes Office Trailer Installation, Vault Modifications, } \\
\text { and } 2736-Z B \text { Complex modifications to accommodate } \\
\text { new stabilization and packaging process equipment. }\end{array}$ \\
\hline $\begin{array}{l}\text { Design - Definitive Design } \\
\text { for } \\
\text { Stabilization Equipment }\end{array}$ & $\begin{array}{l}\text { BWIIC } \\
\text { (Design Authority) }\end{array}$ & CPFF & $\begin{array}{l}\text { FDNW } \\
\text { (Design Agent) }\end{array}$ & $\begin{array}{l}\text { Includes a procurement specification and detailed } \\
\text { drawings for a stabilization glovebox suite. }\end{array}$ \\
\hline $\begin{array}{l}\text { Design - Inner 3013 Can } \\
\text { Weld System }\end{array}$ & $\begin{array}{l}\text { RL, } \\
\text { (BWHC is Design } \\
\text { Authority) }\end{array}$ & IWO & $\begin{array}{l}\text { WSRC } \\
\text { (Design Agent) }\end{array}$ & $\begin{array}{l}\text { Includes the design of an inner } 3013 \text { container welding } \\
\text { system based upon the Savannah River "bagless transfer } \\
\text { technology". }\end{array}$ \\
\hline $\begin{array}{l}\text { Design - Procurement } \\
\text { Specification } \\
\text { For an Outer } 3013 \text { Can } \\
\text { Weld System }\end{array}$ & $\begin{array}{l}\text { BWHC } \\
\text { (Design Authority) }\end{array}$ & RFQ & $\begin{array}{l}\text { TBD } \\
\text { (Design Agent) }\end{array}$ & $\begin{array}{l}\text { Includes the preparation of procurement specification for } \\
\text { an Outer } 3013 \text { Can welding system. }\end{array}$ \\
\hline $\begin{array}{l}\text { Design - Project Safety } \\
\text { Analysis } \\
\text { Documentation }\end{array}$ & $\begin{array}{l}\text { BWHC } \\
\text { (Design Authority) }\end{array}$ & CPFF & $\begin{array}{l}\text { FDNW } \\
\text { (Design Agent) }\end{array}$ & $\begin{array}{l}\text { Includes the Criteria Document. the Preliminary Safety } \\
\text { Analysis Report to authorize construction, and the PFP } \\
\text { FSAR Amendment to authorize operation. }\end{array}$ \\
\hline $\begin{array}{l}\text { Design - Project Fire } \\
\text { Hazards Analysis }\end{array}$ & BWHC & STC & Hughes \& Associ & A project specific fire hazards analysis. \\
\hline
\end{tabular}




\begin{tabular}{|l|l|l|l|l|}
\hline \multicolumn{1}{|c|}{$\begin{array}{c}\text { Contract } \\
\text { Description }\end{array}$} & $\begin{array}{c}\text { Contract } \\
\text { Administration }\end{array}$ & $\begin{array}{l}\text { Performance } \\
\text { Method }\end{array}$ & $\begin{array}{c}\text { Contract } \\
\text { Performed By }\end{array}$ & Comments \\
\hline $\begin{array}{l}\text { Design - Radiological Dose } \\
\text { Assessment }\end{array}$ & BWHC & STC & GTI & $\begin{array}{l}\text { A radiological dose assessment of the stabilization, } \\
\text { packaging, and handling process. }\end{array}$ \\
\hline $\begin{array}{l}\text { Design- Time and motion } \\
\text { computer } \\
\text { Model. }\end{array}$ & BWHC & CPFF & FDNW & $\begin{array}{l}\text { A computer model reflecting the stabilization and } \\
\text { packaging Operations in the 2736-Z Complex which also } \\
\text { integrates the radiological dose information. }\end{array}$ \\
\hline $\begin{array}{l}\text { Construction - Install } \\
\text { Office Trailers }\end{array}$ & BWHC & CPFF & FDNW & $\begin{array}{l}\text { Overall Construction Management responsibility and } \\
\text { Construction Forces support to the fixed-price contractor. }\end{array}$ \\
\hline & FDNW & FP & TBD & $\begin{array}{l}\text { Fixed-price construction contract for the office trailer } \\
\text { Installation. }\end{array}$ \\
\hline $\begin{array}{l}\text { Construction - Vault } \\
\text { Modifications }\end{array}$ & BWHC & CPFF & FDNW & $\begin{array}{l}\text { Includes the 2736-Z vault modifications by Construction } \\
\text { Forces. }\end{array}$ \\
\hline $\begin{array}{l}\text { Construction- Facility } \\
\text { Modifications }\end{array}$ & BWHC & $\begin{array}{l}\text { CPFF } \\
\text { UP }\end{array}$ & FDNW & Exterior modifications to the 2736-ZB building \\
\hline & FDNW & CPFF & FDNW & Construction for the 2736-ZB Facility Modifications. \\
\hline
\end{tabular}

\subsection{SOCIOECONOMIC PROGRAM ELEMENTS}

BWHC is responsible for complying with Department of Energy Acquisition Regulations and Federal Acquisition Regulations for small business and small disadvantaged business concerns, women-owned small business, and labor surplus area concerns (socioeconomic concerns). In implementing the socioeconomic program, the project has identified target procurement and construction package elements that fall under a dollar threshold as candidate "set aside" acquisition actions. (These actions are consistent with the PHMC Subcontracting Plan submitted to RL.) For all acquisitions that exceed the dollar threshold of $\$ 1 \mathrm{M}$, procurement and construction contract documents will include a clause notifying all bidders (other than small business concerns) of the requirement to submit a Small Business and Small Disadvantaged Business Subcontracting Plan for approval after award. Table 4.3 identifies the procurement and construction package elements that have been determined as probable "set aside" actions. The Table also identifies the basic Small Business and Small Disadvantaged Business Subcontracting Plan elements that would be acceptable to BWHC.

Table 4-3 - Project W-460 Summary of Significant Socioeconomic Program Procurement Actions

\begin{tabular}{|l|l|l|l|l|l|}
\hline \multicolumn{1}{|c|}{$\begin{array}{c}\text { Procurement } \\
\text { Description }\end{array}$} & $\begin{array}{c}\text { Estimated } \\
\text { Value }\end{array}$ & $\begin{array}{c}\text { Small } \\
\text { Business }\end{array}$ & $\begin{array}{c}\text { Small } \\
\text { Disadvantaged } \\
\text { Business }\end{array}$ & $\begin{array}{c}\text { Women- } \\
\text { Owned } \\
\text { Small } \\
\text { Business }\end{array}$ & $\begin{array}{c}\text { Labor } \\
\text { Surplus } \\
\text { Area }\end{array}$ \\
\hline $\begin{array}{l}\text { GTI -Project } \\
\text { Administrative Support }\end{array}$ & & $\mathrm{XX}$ & $\mathrm{XX}$ & & \\
\hline $\begin{array}{l}\text { GTI - Dose Assessment } \\
\text { \& Time Motion Study }\end{array}$ & $\$ 137 \mathrm{~K}$ & $\mathrm{XX}$ & $\mathrm{XX}$ & & \\
\hline $\begin{array}{l}\text { Install Office Trailers - } \\
\text { Fixed Price Contract }\end{array}$ & $\$ 350 \mathrm{~K}$ & $\mathrm{XX}$ & & & \\
\hline
\end{tabular}


All acquisition actions include a notice that bidders must comply with the requirements, terms, and conditions of the Executive Order No. 11246, Notice of Requirements of Affirmative Action to Ensure Equal Employment Opportunity (ref 6) for any bid amount that exceeds $\$ 10,000$.

\subsection{PLANT FORCES WORK REVIEW}

Plant Forces Work Review (PFWR) number FDH-003-97 was dispositioned on January 15,1997 , as applicable to construction. This review is included as Appendix $\mathrm{J}$ in the Project W-460 CDR. Due to the fairly major scope change in the W-460 project, an updated PFWR will be prepared to describe the current scope of the project.

\subsection{ENGINEERING AND DESIGN}

BWHC will contract FDNW to perform the conceptual and definitive designs for the Project W-460. Engineering and design will be performed in accordance with FDNW Facility Stabilization Project documents and BWHC task order specific PHMC HNF PRO documents, which are stipulated in the FDNW statement of work.

The engineering and design service provided by FDNW will be performed in accordance with the FDNW Facility Stabilization Project Execution Plan, Facility Stabilization Project Procedures Manual, Facility Stabilization Job Bulletins, Project Activity Plans, Task Specific Activity Plans, and FDNW Practices. These documents provide clear description and precise guidance for engineering and design related activities such as calculation documentation, specification preparation, drawing production, and document control.

Two PHMC procedures that will be stipulated in the statement of work to FDNW will be HNF-PRO-1819, PHMC Engineering Requirements, and HNFPRO-709, Preparation and Control Standards For Engineering Drawings. FDNW will integrate these PHMC procedures into the design process.

The objective of the Project W-460 design will be to provide the necessary utilities, communications, fire protection, safety-related systems, features, and site improvements required to make the SPE operational as required to comply with the project FDC and applicable local, state, and federal codes, regulations, statutes, and standards.

\subsection{A-E RESPONSIBILITIES}

The FDNW A-E responsibilities will include project management services to:

- Provide a single point of responsibility for the day-to-day management of the AE work scope. 
- Provide design services to ensure that established project quality objectives and functional design requirements are satisfied.

- Assure that the design meets the applicable codes, standards, requirements, regulations, and DOE directives.

- Provide constructibility reviews of the design.

- Provide engineering in support of construction including submittal reviews, design changes, nonconformance report disposition, requisitions for safety class material, support of acceptance testing, and as-built drawings of the design.

- Maintain complete A-E project design files by FDNW procedures.

- Provide estimating and scheduling services to support ongoing project needs.

The design review process will be applied to provide a means for the end user organizations to verify that the functional design requirements have been implemented in the designs for the SPE and the facility modifications.

\subsection{DRAWINGS}

Drawings that depict a Hanford structure, system, or component, including those provided by design organizations or other suppliers, shall meet the standards of HNF-PRO-709, Preparation and Control Requirements for Engineering Drawings.

Flow diagrams, P\&IDs, and other schematic drawings will be produced using AutoCAD Version 14 (or other later approved version).

Approved for construction drawings will use the site-standard title block. Engineering Change Notices (ECNs) will be generated by the project for design scope that affects existing PFP essential drawings. This will facilitate the incorporation of "work complete" design changes to facility essential drawings in the time frame dictated by procedure.

\subsection{SPECIFICATIONS}

The project will generate construction specifications to provide a vehicle to fully detail all engineering, quality, and administrative requirements to the construction contractor. Construction specifications will be produced using Construction Specification Institute (CSI) format. The construction specifications will be reviewed and approved in the same fashion as the other project design media.

Procurement specifications will be prepared by the project to support the purchase of engineered equipment or systems where the level of technical and functional requirements warrant this approach. These specifications will support the purchase of MCFE that will be provided to the construction contractor for installation. Procurement requirements for items being purchased by the construction contractor will be stipulated in the construction specification. 
Procurement specifications will be prepared by the project for the following items:

- Change trailer for the office trailer complex

- Stabilization system glovebox suite

- Outer can welder

- Calorimetry equipment

- Radiography equipment

- Process exhaust stack monitoring equipment

- 3013 can handling equipment

The procurement requirements for the inner can welding equipment being provided by the SRS will be stipulated in a MOU between Hanford and SRS.

Procurement documents for safety class and safety significant structures, systems, or components or services shall include the following, as they apply:

- Technical requirements specified by reference to specific drawings, specifications, codes, standards, regulations, procedures, or instructions.

- Identification of test, inspection, and acceptance requirements.

- Quality assurance program requirements to be met by the supplier.

Identification of documentation required to be submitted by the supplier for information, review, or approval by the purchaser, including the submittal schedule [10 CFR 830.120(c)(2)(iii)].

Safety class and safety significant structures, systems, or components shall be procured as either commercial grade items (CGIs) or from an approved supplier. For an item to be procured as a CGI, all of the following criteria must be met:

- The item is not subject to design or specification requirements that are unique to nuclear facilities (NOTE: Nuclear facilities are defined in 10 CFR 830.3.).

- The item is used in applications other than nuclear facilities.

For safety class and safety significant structures, systems, and components, it shall be demonstrated that each procured CGI is suitable for use in its intended application and that the item will perform its safety function. This requires a documented engineering evaluation that establishes and verifies critical characteristics before the item is relied on for operation. Safety functions shall be consistent with the structure, system, or component safety analysis and other authorization basis documents.

The item is ordered from the manufacturer/supplier on the basis of specifications set forth in the manufacturer's published product description (e.g., a catalog or national standard such as American Society for Testing and Materials). 


\subsection{POLLUTION PREVENTION AND WASTE MINIMIZATION REQUIREMENTS}

Design media shall be prepared to comply with federal, state, and DOE pollution prevention and waste minimization requirements in accordance with HNF-PRO-462, Pollution Prevention.

\subsection{CALCULATIONS}

Design calculations used for a design baseline shall be identifiable by subject (including structure, system, or component to which the calculation applies), originator, reviewer, date, or by other data so that the calculations are retrievable [10 CFR 830.120(c)(2)(ii)].

Design analysis documents using computer calculations shall include in the document the computer type, computer program (i.e., name), revision identification, inputs, outputs, evidence of or reference to the computer program verification, and the bases (or reference thereto) supporting application of the computer program to the specific physical problem.

Computer software used in performing calculations and analyses shall be verified and validated for use before approval of the design baseline documents. Verification and validation methods for software shall be preformed in accordance with HNF-PRO-309, Computer Software Quality Assurance Requirements.

All calculations and analyses shall be checked to ensure completeness and accuracy. The person checking the calculations shall not be the person who prepared the original document.

\subsection{DOCUMENT CONTROL AND DISTRIBUTION}

Approved design media generated by the project will be released into the LMSI document control system for use during the construction phase of the project.

Procedure HNF-PRO-440, Engineering Document Change Control Requirements, will be used effect changes to the approved design media. A project specific distribution list for design media will be provided to LMSI by the BHWC Project Manager.

\subsection{CONFIGURATION MANAGEMENT}

Refer to Element 21 of this document for configuration management.

\subsection{INTERFACE CONTROL WITH EXISTING SYSTEMS/FACILITIES}

Interface control diagrams will be developed as needed to clearly delineate the key interface points between the SPE and existing facility systems. An example of this would be the interface between the new process exhaust system and the existing 
Micon ${ }^{\circ}$ control system. Interface control diagrams may also be utilized where warranted to clarify the interface between vendor equipment designs and the A-E facility design.

\subsection{ENGINEERING AND DESIGN PROJECT CONTROLS/CHANGE CONTROL}

HNF-PRO-440, Rev. 1, defines the requirements associated with the development, review/approval, release, and incorporation of changes to engineering documents through the use of the ECN and applies to all engineering documents released into the PHMC engineering release system, except vendor information.

\subsection{AS-BUILT DRAWING REQUIREMETNS}

The vendor or design organization that prepares drawings shall "as-built" the drawings that have been designated by the Design Authority. An as-built drawing shall have all work completed, changes incorporated and be field verified to ensure that the drawing reflects the actual completed installation (i.e., remove reference to construction specifications) and conforms to the design requirements. The as-built drawing status shall be designated in the Hanford Document Control System. When the drawing is revised, the statement "as-built" shall be added to the drawing.

\subsection{CONSTRUCTABILITY, OPERABILITY, AND MAINTAINABILITY REVIEW}

Review for Construction/Maintenance/Operation will be included as part of the design reviews. Similarly, reviews will include pollution prevention and waste minimization efforts.

\subsection{DESIGN REVIEWS TO ASSURE COMPLIANCE WITH CODES, STANDARDS, AND REQUIREMETNS}

Refer to Element 17 of this document.

\subsection{WALKDOWNS OF EXISTING FACILITIES/FIELD INVESTIGATIONS}

Field walkdowns may be required to fully understand the scope of work and to determine the existing condition of the work site. Requirements for pre-job safety planning (including radiological protection), a job safety analysis, and work release and control shall be met before beginning any field activities.

Walkdowns performed to verify the location and configuration of items, structures, components, wiring, etc., that are used to generate change or as-built design media shall be documented and retained with traceability to the associated design document. 


\subsection{ALARA, LIFE-CYCLE APPROACH TO RADIATION DOSE, CONTAMINATION, AND RADIOLOGICAL WASTE}

Companies or organizations which perform radiological design for Project W-460 will be required to comply with the PHMC as low as reasonably achievable (ALARA) program, including ALARA Training, Plans and Procedures (i.e., the company or organization must describe how they meet the ALARA requirements), ALARA Design Review (refer to HNF-PRO-1622, "Radiological Design Review Process"), Optimization Methodology (refer to HNF-PRO-1621, "ALARA Decision Making Methods"), and ALARA Records. In addition, BWHC has oversight authority and ultimate responsibility for all radiological design.

Sub-contractor personnel who perform radiological design will be required by contract to be trained to perform this function.

\subsection{QUALITY ASSURANCE}

Refer to Element 18.0 of this document.

\subsection{VENDOR DATA}

The BWHC Project Manager (PM) will arrange to have a Project W-460 Vendor Information (VI) file established. The BWHC PM shall provide the A-E a list of project equipment and components that apply to this VI list. The A-E shall ensure that the contractor submittal requirements in the procurement and construction specifications support the VI list. At project completion, the BWHC PM will assure that all the project VI related information has been submitted to LMSI for inclusion in the official file. Vendor information items shall be uniquely identified and retrievable.

\subsection{ENGINEERING DURING CONSTRUCTION}

FDNW shall provide engineering services during the construction phase of the project. These services include:

- Review of contractor submittals

- Resolution of design problems during construction

- Generation of ECNs as needed

- Disposition of non-conformance reports

- Participation in acceptance testing

- Prepare design as builts

\subsection{WORK BREAKDOWN STRUCTURE}

The work breakdown structure for project W-460 is reflected in the CDR estimate and is as follows: 
$1.0 \quad$ Engineering

1.1 Definitive Design (FDNW)

1.2 Engineering and Inspection during Construction (FDNW)

1.3 Acceptance Inspection (FDH)

$2.0 \quad$ Procurement

2.1 Stabilization System (FDNW)

2.2 NDA Laboratory Equipment Calorimeters \& Stack Monitoring (BWHC)

2.3 Outer Can Welder (BWHC)

2.4 Change Trailer for Office Complex (FDNW)

2.5 SRS Bagless Transfer System (Inner Can Welder) (RL)

2.6 Process Stack Monitoring Equipment (BWHC)

3.0 Construction

3.1 Office Trailer Installation

3.2 Facility Modifications

3.3 Vault Modifications

4.0 Project Management (BWHC)

5.0 Other Project Costs (BWHC)

\subsection{PERFORMANCE BASELINE DEFINITION \& CONTROL}

The performance baseline comprises the integrated scope baseline, cost baseline, and schedule baseline. The integrated scope baseline includes both facilities scope and services scope.

\subsection{TECHNICAL BASELINE}

The current revision of the DC for Project W-460 establishes the technical baseline for the project. During design, technical baseline monitoring is performed through participation in design reviews. Design reviews are conducted during the design evolution to verify that the evolving design conforms to the FDC and, as appropriate, the specific work scope documents. These reviews are scheduled at specific points during the definitive design. Design review meetings will bring together the key technical project participants.

As a minimum, Project W-460 definitive design will have 50 percent and 90 percent design reviews (refer to Element 17 of this document). They are intended to:

- Verify that the design is in conformance with the approved baseline requirements.

- Ensure technical agreement on the design approach.

- Verify adequacy of the design definition.

- Review progress. 
During fabrication, construction, and equipment installation, monitoring adherence to the technical baseline will be performed through the management of contracts.

During test phases, monitoring adherence to the technical baseline is performed through comparison of test results with the specific design requirements. Following completion of the definitive design, the approved design media (i.e., drawings and specifications) also become controlling technical documents.

\subsection{SCHEDULE BASELINE}

The schedule baseline is established by this PEP. Project integrated schedules, which identify all activities required to ensure the project success and to support the project summary schedule, will be maintained and updated throughout all phases of the project. BWHC will maintain the integrated project schedule. The project integrated schedule includes, as appropriate, the following:

- Design, construction and procurement

- Project management

- Supporting activities (i.e., Preliminary Safety Analysis Report (PSAR), revisions/updates to safety documentation)

- Regulatory activities and milestones

- Operation interfaces

- Acceptance testing

- Construction completion (CCD Section Ia, Ib \& IIa)

- Operational testing

- Critical decisions (see Appendix B for Project critical decision path forward)

- Project completion (CCD Section IIb)

The current revision of the Project CDR identifies the schedule objectives for the project. Table B-1 (Appendix B) provides a summary of the major schedule objectives of the higher level WBS elements of the project which will be used. Appendix A provides more detailed schedule information. Currently there are two DOE milestones on the W-460 project: TRP-99-415-Complete W-460 Facility Design by $3 / 30 / 00$ and TRP-99-502-Complete BTS installation by $10 / 31 / 00$. There are no DNFSB milestones for the project.

Reviews of the project schedule will be made by all project participants and will also be reviewed as part of the formal project validation process. This in conjunction with the input from the project risk assessment process (Element 10.0) will be used to provide a very high schedule confidence. The schedule critical path will managed to ensure critical milestones and objectives are maintained. 


\subsection{COST BASELINE}

The project cost baseline is established in this PEP and is based upon the revised CDR estimate with subsequent confirmation via independent review(s) of the estimate and a formalized project validation process.

Assurance that the value of the approved cost estimates is sufficient to complete the project will be accomplished through periodic reviews of new data consisting of actual costs and trend information that will help predict future costs.

If cost performance evaluations identify variances greater than the established thresholds, analyses will be performed to determine the cause and the appropriate corrective action. Variance analysis provides the opportunity to identify problems and to obtain whatever guidance and resources are required for resolution.

Estimates at completion (EAC) will be developed monthly throughout the design and construction of the project. This information will be forwarded to FDH and RL. EAC forecasts should represent the sum of the actual cost and estimates to complete, with consideration given to:

- Latest performance data.

- Current assessment of changed conditions.

- Current, realistic pricing factors and rates.

- Knowledgeable forecasts of conditions that are likely to exist in the future (based on rationally supportable analyses).

Contingency will address unknown cost impacts that occur during the design and construction phases of the project. The contingency allowance is not expected to cover impacts due to items such as changes in fiscal year (FY) budgets, significant scope additions, and new regulations or imposed criteria outside the control of the project. Refer to Element 13.0 of this document for contingency management.

The project baseline for capital costs is to complete the project within a Total Estimated Cost (TEC) of $\$ 36,100,000$. Estimated expense funded support costs [Other Project Costs, (OPC)] are $\$ 5,100,000$. There are no capital equipment not related to construction (CENRTC) costs. The TPC for this project is $\$ 41,200,000$.

This project was validated in February 1997 as a FY 1998 Line Item project based on the original CDR estimate and schedule. In the fourth quarter of FY 1999, the CDR was revised to support a late project revalidation reflecting the change in project direction away from the national Plutonium Stabilization and Packaging (PuSAP) procurement action. Table B-2 (Appendix B) reflects the current cost baseline objectives for the project at a summary WBS level. 
The estimate information summarized in Table B-2 (Appendix B) will provide a very high confidence level because of the following considerations:

- The estimate associated with the revised Project CDR will undergo project participant reviews, $\mathrm{RL}$ independent reviews, and a formal validation process.

- There is a good confidence level in the source information for the major equipment costs.

- Portions of the design used for the estimate basis were beyond the conceptual level of detail (e.g. Office Trailers and Vaults).

\subsection{BASELINE CHANGE CONTROL}

Baseline changes are authorized by approval of a change request in accordance with procedures HNF-PRO-533.

\subsubsection{Technical Change Control}

Authorization to change the technical requirements established in the FDC will be by ECN in accordance with HNF-PRO-440.

\subsubsection{Cost and Schedule Change Control}

Project baseline change control practices will be in compliance with PHMC procedure HNF-PRO-533, Change Control. Change Control approval thresholds are identified in Section 2.5 of HNF-PRO-533. Method to control the use of contingency to manage changes within the baseline scope are detailed in Element 13.0.

\subsection{LIFE CYCLE COST}

A life-cycle cost analysis was not conducted during pre-conceptual design activity. In the original work scope associated with Revision 0 of the CDR, the decision to establish the SPE configuration was provided at the national level. According to the national level decision, the SPE for PFP was the British Nuclear Fuels Ltd (BNFL) system that was developed at the Rocky Flats Environmental Test Site. The equipment was to be procured from. BNFL through application of a DOE national procurement action. Due to the prescriptive attribute for this procurement, a life-cycle cost analysis was not applicable to most portions of the initial PFP Project W-460 conceptual design.

A life cycle cost analysis was performed for the portion of the original project conceptual design scope related to the use of a dry air supply system for the BNFL SPS versus a nitrogen gas supply system. This LCCA was included in the CDR and has been updated in the revised CDR. 
A path forward decision process for Project W-460, which incorporated life cycle cost considerations, was initiated after the initial conceptual design was completed. Following the initial conceptual design effort, the DOE directed Hanford to evaluate alternative systems for use at PFP. This direction was motivated by technical issues and cost growth associated with the prototype BNFL system that was developed at the Rocky Flats Environmental Test Site. This evaluation involved participation from a wide cross section of program and technical personnel from within the DOE complex.

Seven options were developed for the alternative systems evaluation requested above. A simplified Kepner-Tregoe decision analysis process was applied to analyze the data for the seven options. Analytical parameters included life cycle costs, cost profiles, safety considerations, technical maturity, complexity, construction schedule, operating schedule, and programmatic issues. This decision process resulted in a recommendation for the project to deviate from the original automated stabilization and packaging system baseline and to use SRS bagless transfer technology to produce a welded inner container.

The bagless transfer technology option provides added stabilization capability and provides the capability to apply a 3013 compliant outer container.

\subsection{COST CONTROL}

Project W-460 project manager's responsibilities include consideration of cost impacts to the project budget, including: selecting the appropriate contracting tools, procurement, inspections, evaluations, and disposition of change requests. Project costs will be monitored daily via time cards and procurement reports), recorded weekly, and reported monthly. Undesirable trends will be evaluated and recorded and corrective action will be taken. The Cost Performance Report is submitted monthly and includes problem and variance analysis and cost performance by Baseline Summary and WBS element. Variance analysis are prepared for accounts that fall outside of established project thresholds. Schedule status reporting percent complete and remaining duration at the task level will drive the Hanford Financial Data Integration system cost reports. Information contained in these reports is obtained from the same database that supports day-to-day management by BWHC.

\subsection{PROJECT (CONSTRUCTION) RISK}

This element of the PEP identifies both internal and external factors that may individually or in combination present potential risk to one or all of the Project's objectives. In this context, the Project's objectives shall be maintenance of the technical, cost, or schedule baseline.

As stated above, there are internal and external risk factors, some of which may have a positive influence upon the Project baselines, as well as those factors, which may have a negative influence. Element 10 details only those Project processes for managing the negative influences (adverse risks) to the Project baselines. Specifically, this element identifies the potential risk, performs an assessment of the potential risk and 
delineates special management techniques in analyzing the adverse (negative) risk influence upon one or all of the Project's baselines (technical, cost, and schedule). The identification of risk factors influencing the Project baseline, the process of quantifying and analyzing the influence of the risk factors, and control of the effects of the risk factors upon the Project baselines are key to successful execution of the Project.

\subsection{RISK ASSESSMENT PROCESS}

Element 10 is the PFP recommended risk assessment process delineated in the Integrated Project Management Plan for the Plutonium Finishing Plant Stabilization and Deactivation Project, HNF-3617, Rev. 0, prepared by BWHC.

\subsection{RISK ASSESSMENT FACTORS}

Project W-460 was analyzed for potential influences to a standard risk factor listing. A listing of the potential influences (risk contributors) to Project W-460 is stated in Table 10-2.

Three project areas require special discussion.

A major risk to the Project is the work inside an operating facility (2736-ZB). This work will require the coordination of construction material, equipment and personnel with the operation and security needs of the facility. Windows of opportunity will have to be aggressively managed to ensure the operating facility is not compromised. This is of particular importance during the installation of the stablilzation and packaging equipment as well as the SRS supplied BTS glovebox. These needs have necessitated an aggressive performance-driven schedule to support the BTS glovebox installation window. Should a slip occur, multiple construction shifts during the installation window is the only avenue for recovery.

A second risk worthy of discussion is the management of the cost and schedule of the Savannah River Bagless glovebox. The glovebox will have to arrive at Hanford on time to maintain the installation window at 2736-ZB and follow-on operational startup milestone. Any major cost overruns by WSR will directly impact the entire project. To ensure success of existing planning, all project phases will be monitored with any deviations quickly addressed for impacts. Corrective action/recovery plans will require immediate formulation and implementation. Current planning will re-locate BWHC project individual to Savannah River ensuring Hanford's interests is maintained. 
Table 10-1 - Project W-460 Tabulation of Risk Contributors (Sample)

\begin{tabular}{|c|c|c|}
\hline $\begin{array}{c}\text { RISK } \\
\text { FACTOR }\end{array}$ & RANK & RISK CONTRIBUTORS \\
\hline$\overline{\text { Technology }}$ & & $\begin{array}{l}\text { Bagless: The project will utilize technology developed at the SRS. Although the Bagless } \\
\text { technology is new to the Hanford Site and the Hanford unit will contain some Site-Specific } \\
\text { changes, SRS has a similar unit in operation at this time. The unit SRS will supply to Hanford } \\
\text { will share many of the features and components already in operation at WSRC's facility, } \\
\text { Stack Monitor: The Project proposes to use a stack monitoring unit based upon an existing } \\
\text { application: Project W-420, Ventilation Stack Monitoring System Upgrades. HNF-S-0400, } \\
\text { Generic Effluent Monitoring System. } \\
\text { Mardex: The Project will relocate existing cquipment and the design will accommodate alternate } \\
\text { entrance during the change out. } \\
\text { Balance of Facility Design (Complexity): The balance of facility design will detail simple, } \\
\text { proven technology with many systems similar to current facility systems. } \\
\text { Operability/Maintainability: Material/ product flow into and out of the stabilization and } \\
\text { packaging gloveboxes do not present unusual process characteristics and are similar to past } \\
\text { practice process at the PFP facility. } \\
\text { Acceptability: Project will send a core team of process operators to SRS to obtain first hand } \\
\text { knowledge of Bagless technology. Remaining glovebox operations similar to existing processes } \\
\text { at PFP. }\end{array}$ \\
\hline Interfaces & & $\begin{array}{l}\text { Savannah River Site: A MOU is being developed to state the operating parameters between } \\
\text { WSRC and BWHC. The MOU will detail scope, administrative instructions, reporting } \\
\text { expectations, and deliverables and timetables among other things. BWHC will send an } \\
\text { individual representative to SRS to monitor progress and act as on-site client representative. } \\
\text { IAEA: The interface with the IAEA presents some uncertainties around accommodating period } \\
\text { inspections. } \\
\text { Procurement Vendors: BWHC has an established and experienced government procurement } \\
\text { group with in the Hanford family that has established vendor relationships through out the area. } \\
\text { A vendor rating system is maintained. } \\
\text { AECM (FDNW): A long and well-established relationship exists between the AECM and } \\
\text { BWHC. The AECM has many years of experience supplying successful execution of design, } \\
\text { engineering. and construction projects at PFP and glovebox processes. No adversarial } \\
\text { relationship exists. } \\
\text { Plant/Operations: A working dialogue exists between the Project and the Plant and the } 2736-Z B \\
\text { facility. } \\
\text { Security: A Project needs dialogue has been established with the facility security personnel for } \\
\text { both physical and material requirements. } \\
\text { Other Factors: No other interface impacts are anticipated from operations, contractors, or } \\
\text { programs. }\end{array}$ \\
\hline Safety & & $\begin{array}{l}\text { Construction: Established contractor with an approved and monitored safety program. On-site } \\
\text { construction contractor has just obtained } 1 \text { million man-hours without a loss time injury award. } \\
\text { Hazards: Are well documented and understood. Past work in the areas being modified give a } \\
\text { high level of confidence that radiological hazards can be managed using normal RadCon work } \\
\text { techniques. } \\
\text { PSAR: Project and the BTS system have an existing (draft) preliminary safety basis with } \\
\text { accident scenarios identified. }\end{array}$ \\
\hline $\begin{array}{l}\text { Political } \\
\text { Visibility, } \\
\text { Stakeholder } \\
\text { Involvement }\end{array}$ & & $\begin{array}{l}\text { DNFSB: Periodic reviews and presentation of progress and issues will be given to the DNFSB. } \\
\text { The relationship with the DNFSB is similar to other Projects. }\end{array}$ \\
\hline Funding & & $\begin{array}{l}\text { Multi-Year Outlay: BA/BO funding streams established and large percentage of out year funding } \\
\text { requirements satisfied by current year carry over. }\end{array}$ \\
\hline
\end{tabular}




\begin{tabular}{|c|c|c|}
\hline $\begin{array}{c}\text { RISK } \\
\text { FACTOR }\end{array}$ & RANK & RISK CONTRIBUTORS \\
\hline $\begin{array}{l}\text { Time/ } \\
\text { Schedule/ } \\
\text { Costs }\end{array}$ & & $\begin{array}{l}\text { Schedule: Aggressive, demand project schedule required to meet IPMP (PFP) commitment } \\
\text { Project cost and schedule contingencies will reflect high risk factor. } \\
\text { Resource Loaded Schedule: A project detailed, resource loaded schedule has been developed } \\
\text { and cross-walked with the project WBS and cost collection identifiers. } \\
\text { Scope Creep: Major down fall of Hanford projects is 'scope creep', particularly during the latter } \\
\text { stages of the Project's life, testing stages and Operation Readiness Review. } \\
\text { Estimate and Activity Duration Busts: Experienced personnel familiar with the requirements of } \\
\text { work inside PFP secured boundary. cost of material and labor for this locality will supply input on } \\
\text { develop the baseline estimate and schedule duration. This is not an exact science and appropriate } \\
\text { project contingency will be applied to both these baselines. } \\
\text { Experienced Personnel: Construction supervision and core craft are experienced in the PFP work } \\
\text { environment, (security, radiological and JCS requirements). } \\
\text { Working Assumptions: Working assumptions are documented and transmitted to team members. } \\
\text { Dedicated resource identified to close on assumptions with PFP plant operations and engineering. }\end{array}$ \\
\hline $\begin{array}{l}\text { Site } \\
\text { Characteristics }\end{array}$ & & $\begin{array}{l}\text { Site: simple DOE site, accessible with somer degree of inconvenience due to security } \\
\text { requirements. } \\
\text { Access to Site: Restricted to standard working hours, primarily during the day. Off shift } \\
\text { working hours with approval and additional oversight. Escorts required for non-clearance } \\
\text { personnel. } \\
\text { Drill/Evacuation: Activities during construction is subject to periodic (announced) emergency } \\
\text { exercises, and other life science drill and exercises. }\end{array}$ \\
\hline Labor & & $\begin{array}{l}\text { Skill: On-Site construction craft are highly skilled in their 'tools of trade' and trained to the } \\
\text { procedural requirements for work inside PFP. } \\
\text { Availability: The local labor halls have highly skill labor on the bench to supplement the on-site } \\
\text { construction contractor ( } 2736-Z B \text { work) and any small to medium sized contractor (trailer } \\
\text { installation). }\end{array}$ \\
\hline $\begin{array}{l}\text { Quality } \\
\text { Requirements }\end{array}$ & & $\begin{array}{l}\text { Irailer Installation: Commercial type quality requirements commensurate with the design } \\
\text { requirements. Successful subcontractor will be required to demonstrate a quality program and } \\
\text { first line inspection capability commensurate with the commercial type construction. On-site } \\
\text { construction management will have quality oversite requirements. } \\
\text { 2736-ZB: Safety and Safety Significant components. Performing on-site contractor (FDNW) } \\
\text { possesses an approved quality program and first line inspection capacity with a proven quality } \\
\text { capability at Hanford and at PFP. }\end{array}$ \\
\hline $\begin{array}{l}\text { Number of Key } \\
\text { Participants } \\
\text { (internal and } \\
\text { external) }\end{array}$ & & $\begin{array}{l}\text { Internal: } 5, \mathrm{BWHC} / \mathrm{FDH} / \mathrm{DOE} / \mathrm{PNNL} / \mathrm{WMHC} \\
\text { External: } 5, \mathrm{FDNW} / \mathrm{WSRC} / \mathrm{GTI} / \mathrm{Const} \text { Subcontractor/Hughes \& Ass./Williams }\end{array}$ \\
\hline $\begin{array}{l}\text { Contractor } \\
\text { Capabilities }\end{array}$ & & $\begin{array}{l}\text { Trailers: Limited experience is required to manage and construct this package. Security and } \\
\text { documented safety requirements do complicate a normally commercial practice installation. } \\
\text { Proven track record and resources available } \\
\text { 2736-7.3: Complicated modification to an existing and operating facility. On-site contractor has } \\
\text { proven track record and immediately available resources. }\end{array}$ \\
\hline $\begin{array}{l}\text { Regulatory } \\
\text { Involvement }\end{array}$ & & $\begin{array}{l}\text { Permits: Routine permitting requirements with multiple agencies, (NEPA-SA, NOC-minor } \\
\text { emission source). Some negotiation with agencies required. }\end{array}$ \\
\hline $\begin{array}{l}\text { Magnitude and } \\
\text { Complexity } \\
\text { Contamination }\end{array}$ & & $\begin{array}{l}\text { Trailers: No potential for chronic or acute exposure to chemical or radiological hazards. High } \\
\text { confidence in the characterization industrial, chemical, and radiological hazards. Subcontractor } \\
\text { will be required to satisfy rigid health and safety requirements prior to award. } \\
2736-Z B \text { : On-site construction contractor with many years' experience working in environments } \\
\text { like } 2736-Z B \text {. Potential for chronic or acute exposure to well defined chemical or radiological } \\
\text { hazards. On-site contractor has an excellent ALARA/HAZCOM/Rad Con and Industrial safety } \\
\text { program performance record }\end{array}$ \\
\hline
\end{tabular}


A final special area of concern covers the risk of 'low' senior management project visibility. In the past, the availability of funding due to competing priorities has affected the project schedule and this has the potential to affect future project plans. To reduce the potential for budget compromise, the project team must have a sponsor to communicate the importance of project W-460, as it relates to other ongoing activities to senior management. This same concern relates to competing for PFP resources. The project will need to clearly identify the PFP resources that are needed to support construction and testing activities and to assure that these are factored into integrated planning for the facility. The current PFP infrastructure can reasonably support only a limited number of parallel operation and construction activities. A senior level sponsor could elevate critical needs in these areas particularly when an outside resource will not adequately fill the need or the project schedule baseline can no longer absorb the delay.

\subsection{CONTROLS}

The project team will control the risk to the technical, cost, and schedule baseline by employing one or more of the following methods, as needed:

- The use of checklists to manage critical functions

- Self assessments, primarily to manage procedural compliance

- Perform workarounds, where timing is critical

- The use of Corrective Action Plans when a formal response and follow-up is required

Periodic Project reviews and updates to risk identification process will be conducted as directed by the BWHC W-460 Project Manager.

\subsection{RISK MANAGEMENT PLAN}

A project specific risk management plan, beyond the level of detail identified in this $P E P$, is not planned for this project.

\subsection{PERFORMANCE MEASUREMENT, REPORTING, AND FORECASTING}

Project W-460 performance will be monitored at least monthly by the performing organization $\mathrm{BWHC}$ who will provide current performance evaluations against the established baseline from the planning phase to RL and FDH. The process will have an upward flow of integrated, summarized information to RL and FDH, ensuring timely management decision-making by the project team. This is accomplished by the following:

- A Project Performance Report will be prepared monthly for project review meetings with the appropriate RL and PFP organizations. Project participants will include personnel from RL, FDH, BWHC, and FDNW. The performance reviews 
focus on significant accomplishments since the previous meeting; expected accomplishments for the next month; major problems and issues facing the project; corrective actions; contingency usage; and cost, schedule, and technical status.

- BWHC will obtain technical, schedule, and cost, information in the format and level of detail necessary to meet management and reporting needs. Resources are assigned based on actual task duration, industry standards, and historical data. Baseline cost and schedule versus actual performance will be measured. The project funding profile will be correlated with planned commitments, expenditures, and work accomplished to date.

- BWHC will be responsible for preparing and issuing the agenda and recording action items, agreements, and commitments that result from performance reporting.

- The Cost Performance Report includes problems and variance analysis and cost performance by program baseline summary and work breakdown structure (WBS) element $\left(8^{\text {th }}\right.$ Level of WBS). Variance analyses are prepared for accounts that fall outside of established project thresholds (thresholds are $\pm 10 \%$ and $\pm \$ 10,000$ for YTD BCWS under $\$ 50,000$ and $\pm \$ 50,000$ for YTD BCWS over $\$ 500,000$ per HNF-MD-018, Rev. 0). BWHC will prepare and issue monthly project reports including the narratives, work complete and current status, expenditures to date, TPC, Actual Cost Work Performed, Budgeted Cost Work Performed, Budgeted Cost Work scheduled, variance analysis, cumulative physical percent complete, estimate at completion, and a schedule detailing the remaining duration (in working days) of major activities.

- BWHC will maintain trends to evaluate and analyze the information to identify key problems that require management decisions for method of recovery and corrective actions.

\subsection{FUNDING (STRATEGY TO ASSURE CONTINUITY OF FEDERAL FUNDING)}

\subsection{FUNDING METHODOLOGY}

A Budget Authority/Budget Outlay schedule (BA/BO) has been developed as part of the CDR. This schedule reflects the capital and expense funding that will be needed on a fiscal year basis to support the construction project objectives. This schedule will be consistent with the Construction Project Data Sheet and the Multi-Year Work Plan (MYWP) to assure that project-funding needs are in sync with program plans.

The request for capital budget authorization shown on the BA/BO schedule for a given fiscal year will cover anticipated expenditures plus any capital carryover that is needed to assure continuity in funding through the first quarter of the following fiscal year. This carryover would cover any delays in implementing the new fiscal year funding in the performance contractor's financial system. In addition, the funding authorization should include up front costs to cover contract commitments. 
The $\mathrm{BA} / \mathrm{BO}$ schedule will also show the planned budget outlay for each fiscal year. The difference between the cumulative budget authorization requested and the cumulative planned budget outlay will represent the planned budget carryover for the following fiscal year.

\subsection{HISTORY}

Project W-460 was validated in Fiscal Year 1998 at a Total Estimated Cost (TEC) of $\$ 36,600,000$ and a Total Project Cost (TPC) of $\$ 44,100,000$. This is consistent with information supplied to the MYWP for FY 98. A BA/BO multi-year funding profile was developed based upon the anticipated progress requirements generated from the Project Schedule.

Early in FY 1999, Project W-460 funding profile was revised by Baseline Change Request (BCR) FSP-99-010, which deferred (spread) current expense and capital fiscal year dollars into project outyears. In addition, BCR FSP-99-010 acknowledged an increase in the W-460 baseline to $\$ 46,100,000$ to account for adjustments to current site adders and liquidation rates from the original CDR estimate. Subsequent to the submittal of BCR FSP-99-010, the project has conducted an evaluation of alternatives to the initial material packaging and handling system validated the previous year. The outcome of the Project W-460 alternative studies is a preferred packaging method based upon the SRS BTS.

BCR FSP-99-021 was developed to address the planning phase of the project to accommodate the new project direction. BCR FSP-99-022 was developed to address the comprehensive changes resulting from the new project direction which formed the basis for revision 1 to the CDR. Appendix E shows a summary of the changes from the previous project baseline reflected in BCR FSP-99-021 to the current baseline shown in FSP-99-022.

\subsection{BA/BO STRATEGY}

The W-460 PM will trend the cost estimate included in the revised CDR through detailed design and into construction. This analysis will reflect actual and forecast trends to ensure that adequate funds are available for all project activities as scheduled. This analysis will be conducted on a monthly basis or on a more frequent basis depending upon the Project demands. This analysis is necessary to ensure all planned activities, including pending change requests and/or potential claims, will have sufficient funds to cover the forecasted obligations in any fiscal year.

\subsection{BA/BO PROFILE}

Table G-1 in Appendix G shows the current project W-460 BA/BO funding profile for the project. This particular BA/BO profile incorporates the projected outcome of the Project redirection to the SRS BTS as reflected in the July 1999 revision to the Project CDR. 


\subsection{MANAGEMENT}

\subsection{APPLICATION OF CONTINGENCY}

Contingency has been provided in the project baseline to cover costs that may result from incomplete design, unforeseen and unpredictable conditions, or uncertainties within the defined project scope. The contingency allowance is not expected to cover impacts due to items such as changes in FY budgets, significant scope additions, and either new regulations or imposed criteria outside the control of the project.

The cost baseline for Project W-460 is established with information provided by the CDR estimate and by subsequent confirmation through independent review(s) of the estimate and through a formalized project validation process. The application of contingency for this project will follow the guidance in Chapter 11 of DOE Order G 430.1-1, Cost Estimating Guide and procedure HNF-PRO-585, Cost Estimating. A contingency analysis was performed to document the rationale for the application of contingency in the estimate.

The cost baseline with the contingency identified by each major WBS is shown in Table 7.2. Total Estimated Costs.

\subsection{USE OF CONTENGENCY}

The BWHC Project Manager will approve the use of all contingency and maintain a summary log of total contingency used to date. The BWHC Project Manager will direct the use of project contingency for baseline estimate uncertainties. In accordance with HNF-PRO- 533 , when $50 \%, 75 \%$, and $90 \%$ of current, validated line item total construction project baseline contingency use is reached, the FDH Director must provide the FDH Change Control Board and RL Assistant Manager Contracting Officer's Representative with the following information:

- Current project status

- Summary log of contingency use to date

- Relative risks to project completion with remaining contingency

The use of contingency will be suspended pending evaluation of this information and authorization to proceed by the FDH Change Control Board.

The BWHC Project Manager will get FDH Change Control Board and RL Assistant Manager Contracting Officer's Representative approval to use line item construction project contingency for scope changes. 


\subsection{ENVIRONMENTAL, LICENSING, AND PERMITTING STRATEGY (NEPA, ETC.)}

The National Environmental Policy Act (NEPA) documentation, which addresses the stabilization and repackaging process to be established, is discussed in the PFP Environmental Impact Statement (DOE/EIS-0244-F). A Record of Decision for the PFP EIS was received in June 1996.

It is anticipated that additional NEPA analysis will be required for construction associated with infrastructure upgrades needed to accommodate the SPE. A supplemental analysis, which is sub-tier to DOE/EIS-0244-F, will be developed for Project W-460 and will address this work scope.

The project will not pursue a Notice of Construction (NOC) for the work scope associated with the Office Trailer installation. If radiological contamination should be found, all work will stop and a NOC would be processed prior to the restart of work. This schedule risk is considered minimal based upon historical data from excavations in this area by recently completed Projects L-281 and C-218. The sewer for the new office trailers being installed for Project W-460 will be tied into the lift station recently installed by Project L-281.

The project will require a new process exhaust stack on the 2736-ZB Building to accommodate the SPE system. The new stack will require approval, prior to construction, by the Washington State Department of Health and the U.S. Environmental Protection Agency (EPA). The stack will comply with the National Emission Standards for Hazardous Air Pollutants (NESHAP) standard and will meet all applicable requirements for a major stack.

A summary of all the anticipated permits and approval requirements are listed in Table 15-1, Summary of Potential Permits/Approvals Requirements, for Project W-460. An environmental requirements checklist for Project W-460 is included in Appendix F.

The project integrated schedule will incorporate permitting information. The BWHC PFP Environmental Engineering organization will coordinate all project permitting activities. 
Table 14-1 - Summary of Potential Permits/Approvals Requirements

\begin{tabular}{|c|c|c|c|c|}
\hline $\begin{array}{l}\text { Environment- } \\
\text { Media }\end{array}$ & $\begin{array}{l}\text { Permit, Approval, or } \\
\text { Requirement }\end{array}$ & Regulation & $\begin{array}{l}\text { Regulatory } \\
\text { Agency }\end{array}$ & Restriction \\
\hline NEPA & NEPA Documentation & 10 CFR 1021 & DOE & $\begin{array}{l}\text { Title II Design; } \\
\text { procurement }\end{array}$ \\
\hline $\begin{array}{l}\text { Radioactive Air } \\
\text { Emissions }\end{array}$ & NESHAPS & 40 CFR 61, Subpart H & EPA & Construction \\
\hline $\begin{array}{l}\text { Radioactive Air } \\
\text { Emissions }\end{array}$ & $\begin{array}{l}\text { Radiation Protection - Air } \\
\text { Emissions }\end{array}$ & WAC $246-247-060$ & $\mathrm{DOH}^{*}$ & Construction; operation \\
\hline All Media & $\begin{array}{l}\text { Cultural Resources } \\
\text { Review }\end{array}$ & 36 CFR 800 & DOE & $\begin{array}{l}\text { Any surface disturbance } \\
\text { or modification of } \\
\text { building eligible for } \\
\text { listing on the Historical } \\
\text { Register }\end{array}$ \\
\hline All Media & Excavation Permit & 36 CFR 800 & DOE & Any excavation \\
\hline All Media & $\begin{array}{l}\text { Ecological Compliance } \\
\text { Review }\end{array}$ & $\begin{array}{l}10 \text { CFR } 1021, \\
50 \text { CFR } 402.6, \\
\text { DOE Order } 5484.1\end{array}$ & USFWS & $\begin{array}{l}\text { Construction; habitat } \\
\text { modification }\end{array}$ \\
\hline All Media & $\begin{array}{l}\text { Radiation Protection } \\
\text { Standards }\end{array}$ & DOE Order 5400.5 & DOE & Construction \\
\hline
\end{tabular}

\subsection{INSPECTION, TEST, EVALUATION, TURNOVER/ACCEPTANCE, AND START- UP PLAN}

The information in this section is conceptual in nature and will be refined during the execution phase of the project as the detailed design information becomes available.

\subsection{CONSTRUCTION INSPECTION ORGANIZATION}

The independent evaluation of construction conformity to drawings and specifications will be performed by the FDH Acceptance Inspection (AI) organization. First line construction inspection will be performed by the construction contractor with specific requirements detailed in the associated construction specification.

\subsection{CONSTRUCTION INSPECTION PLAN}

Inspection testing, quality program, and documentation requirements associated with significant procurements will be defined in the procurement specifications developed by the project. The organizations, performing the procurements, will be responsible to verify that the specification requirements have been met by the vendor. 
Inspection, testing, quality program, and documentation requirements will be identified to the construction contractors via the construction specifications prepared as part of the definitive design process. These specifications will clearly identify all construction contractor requirements for inspections, hold points, document submittals, quality program attributes, and testing.

Acceptance Test Procedures (ATPs) addressing the infrastructure modifications being implemented to accommodate the SPE will be developed as part of the definitive design. The construction contractor will be responsible for performing the ATPs for the infrastructure upgrades. FDH's Acceptance Inspection group will be responsible for witnessing and approving the ATPs.

\subsection{START-UP PLAN}

BWHC will develop Operational Test Procedures and will perform the appropriate test to verify the functional acceptability of the installation after successful completion of the ATPs. An Operational Readiness Assessment will be performed to assure that all aspects of the Facility are configured correctly to support operation of the SPE. The project integrated schedule and MYWP will reflect the project and facility actions needed to support the Readiness Assessment.

\subsection{ACCEPTANCE INSPECTION (AI)}

Independent acceptance inspection will be provided to evaluate conformity or nonconformity to the approved drawings and specifications. Inspection will be applied to construction and testing and to source inspection and testing for construction workmanship, materials, and equipment. An Acceptance Inspection Plan is required by DOE-RL prior to the initiation of procurement and construction.

The FDH QA AI organization will provide acceptance inspection services for DOE-RL. The inspection service will be funded by the project. The AI organization will prepare the inspection plans. The work scope covered by these plans will be coordinated with the phased turn over of the project as detailed in Element 16.5.

\subsection{JURISDICTIONAL TURNOVER}

The project will be turned over to the PFP Facility in a phased manner in accordance with HNF-PRO-2000, Construction Program Execution Phase. A Construction Completion Document will be prepared to transfer portions of the project to PFP custody. This phased turn over will facilitate the early acceptance of portions of the project that are not directly tied to the Readiness Assessment of the stabilization and packaging process. Early acceptance of selected portions of the project work scope is advantageous for such things as the immediate use of the office trailers and minimizing operational down time for the NDA Laboratory. It is currently envisioned that partial CCDs will be prepared for the following portions of the project: 
- Office trailers

- 2736-Z vault modifications

- NDA Laboratory modifications

- 2736-ZB security access system

- Stabilization and Packaging Process System (includes all remaining work scope)

A final CCD will be filled out after completion of the final project phase to close out the finished project.

\subsection{DESIGN REVIEWS}

Design reviews will be provided to assure the engineering and design media meets the project requirements. These design reviews will be conducted by unbiased outside experts. They will document that reasonable effort has been made to optimize design. The design reviews will ensure that integrated, competent engineering, and design were applied to address a complete statement-of-work with comprehensive design requirements definition. The design reviews will be conducted against the technical baseline for Project W-460, the FDC. Following completion of the definitive design, the approved design media (i.e., drawings and specifications) also become controlling technical documents.

During design, technical baseline monitoring will be provided by design reviews, which verify that the evolving design conforms to the FDC, and as appropriate, the specific work scope documents. These reviews will be scheduled at specific points during the design process.

Project W-460 definitive design for the facility modifications will have formal 50 percent and 90 percent design reviews. Additional informal reviews may be implemented on selected portions of the design if project management determines that this is needed. The design will be segregated into logical design packages that are structured to support project schedule needs. For instance, a separate Office Trailer design package was generated to accommodate the early installation needs for this work scope. It is currently anticipated that separate design packages will be prepared for the stabilization glovebox equipment specification, the $2736-Z$ vault modifications, NDA laboratory modifications, and the general $2736-Z B$ facility modifications. The 50 percent and 90 percent design reviews will not necessarily be scheduled concurrently for these activities.

Design review meetings will bring together the key technical project participants. The design reviews are intended to:

- Verify that the design is in conformance with the approved baseline requirements.

- Ensure technical agreement on the design approach.

- Verify adequacy of the design definition.

- Review progress. 


\subsection{QUALITY ASSURANCE}

A project-specific QAPP is required for Project W-460 because it is a Line Item Project in the PFP nuclear facility. QA requirements associated with design, procurement, construction, and closeout elements of this project will be planned and implemented in accordance with criteria from 10 CFR 830.120, Quality Assurance, which is invoked for nuclear facilities.

\subsection{QUALITY ASSURANCE PROGRAM PLAN}

BWHC prepared a joint BWHC and FDNW W-460 project-specific QAPP, $H N F-S D-W 460-Q A P P-001$. BWHC and the other PHMC Contractors will prepare and maintain QAPPs in accordance with HNF-MP-599, Project Hanford Quality Assurance Program Description and HNF-PRO-261, Quality Assurance Program Plans. The HNF PROs apply the criteria from 10 CFR 830.120.

BWHC is required to submit their QAPP to FDH for review and approval. Throughout the course of the project, the FDH QA organization will provide applicable oversight inspections and independent assessment.

Other Hanford contractors $(\mathrm{OHC})$ will be required to comply with QA programmatic requirements and QAPP generation in accordance with their BWHC contract task orders and the associated statements-of-work.

FDNW complies with the requirements for QAPP preparation through the use of the joint BWHC and FDNW W-460 project-specific QAPP. In addition, FDNW will apply the FDNW Project Execution Plan and the FDNW Project Procedures Manual, which invoke the FDNW Quality Management Program. FDNW will apply HNF PRO documents that are specified in a BWHC task order for Project W-460.

\subsubsection{Quality Assurance Program Plan Contents}

The importance of work performed and the associated safety implications influence the QAPP contents. The importance will be manifested by the Safety Classification identification assigned to the facility structures, systems, or components (SSC).

Overall quality and reliability requirements for either new or modified plant SSC will be included in the definitive design media, which will incorporate applicable quality programmatic requirements from the QAPP.

Applicable verification that work is properly completed will be incorporated into the definitive design media and work packages. Conditions, which are unacceptable, will be identified and corrected. 
Design, procurement, construction, and closeout activities will be defined and documented through application of appropriate QA requirements. These requirements are identified in the project-specific QAPP.

The minimum required work and documentation will be identified for project definitive design media. Quality verification, either required or specified for the design media, will be the responsibility of the performing organization.

\subsection{APPLICABLE SAFETY CLASSIFICATION DETERMINATION}

The joint project-specific QAPP will incorporate information provided by the evaluations performed to determine the safety classification of the SSC that will be supplied for the project. These safety classification identifiers will be extracted from safety analysis documents and incorporated into the QAPP.

Specific quality requirements will be incorporated into the definitive design media. Quality attributes will be identified and verified, as applicable. The associated safety classification will be determined through application of a graded approach. The graded approach will emphasize appropriate quality requirements as a consequence of the risks involved.

\subsection{APPLICATION OF SAFETY CLASSIFICATION IDENTIFIERS}

The applicable safety classification identifiers will be applied during the execution phase of the Project. This phase includes three main processes, which are the design, procurement, and the construction processes.

Organizations and suppliers that perform design, procurement, fabrication, inspection, and testing activities will comply with quality requirements specified in their contracts.

BWHC will assure that appropriate quality requirements are implemented for procurement of the calorimeters and associated equipment for the 2736-ZB Laboratory.

17.3.1 Application for the Design Phase

Applicable quality standards will be applied during the design phase. Sound engineering standards and scientific principles will be incorporated. The design process will address applicable redundancy for safety class components to ensure system reliability, where applicable. 
17.3.2 Application for the Procurement Phase

Quality related activities, that affect procurement, include document preparation, record retention, identification and tracking of vendor performance criteria and standards, and associated inspection and testing. Either services or material utilized in Safety Class and Safety Significant SSCs will be procured from either evaluated suppliers, which will be identified on the PHMC Evaluated Supplier's List, or through application of Commercial Grade Item Dedication processes.

BWHC and other PHMC Contractor procured material will utilize the FDH Passport system and will have Quality Level designations specified, as applicable.

FDNW Procurement activities will be performed in accordance with procurement practices identified in the FDNW PPM and PEP. These practices will invoke QA Programmatic requirements that are appropriate for the affected SSC Safety Classification.

Other contractors and vendors who are contracted directly to BWHC and FDNW will perform procurement actions in accordance with their evaluated and approved Quality Program.

\subsubsection{Application for the Construction Phase}

During the construction phase, conditions adverse to quality will be identified in deficiency reports, nonconformance reports, audit reports, surveillance reports and corrective action requests, as required. Investigation and corrective actions will be effected in response to these adverse conditions. These actions will be completed in a timely manner.

\subsection{PROJECT CLOSEOUT}

Project closeout will be performed in accordance with procedure HNF-PRO-2000, Construction Program Execution Phase. Quality affecting records will be transitioned to BWHC during the closeout phase. These records are essential elements that are necessary to obtain beneficial occupancy approval and to initiate start-up operations. Quality affecting records will be applied by BWHC to complete the closeout process. These records include project documents such as design media documents, inspection and testing documents, and other contractor documents.

\subsection{SAFETY}

BWHC will produce a Project W-460 safety plan or invoke their company safety manual that will be used to establish safety and health requirements and to give guidance. Two elements of safety will be addressed: construction safety and facility safety analysis. 
Construction Safety

BWHC will ensure that all contracted or subcontracted activities are conducted in a safe manner. Compliance with the Project W-460 Safety Plan will assure compliance with DOE 5480.9A and 29 CFR 1926, Construction Project Safety and Health Management. These requirements will apply to all organizations involved in subcontracting activities within the scope of this project.

All PHMC subcontractors must follow the general procedural steps outlined below to maintain effective interaction with their lower level subcontractors

These procedural activities comprise: activity initiator, contracts administration, PHMC subcontractor/enterprise company safety and health organizations, and construction manager.

BWHC ensures a safe construction project in the following ways:

- BWHC reviews and approves each subcontractors Safety Plan prior to work beginning.

- The construction contractor is required to participate in the preparation of the Job Hazard Analysis to identify and mitigate any hazards expected during construction.

- BWHC provides safety oversight in the field during construction using their on site Safety Professionals.

- BWHC prepares and reviews the detailed work plans for each construction activity using the Job Control System (JCS) to insure that all work is planned and completed in a safe manner.

- For High Risk Radiation Work the Enhanced ALARA Committee provides a detailed review and approval of the Work Plan prior to the release of work.

- BWHC conducts periodic audits of the contractors Safety Program to insure that the contractor is truly adhering to their Safety Plan and following all appropriate safety procedures and requirements.

- Pre-job safety meetings, with all necessary attendees, are held to discuss and mitigate the hazards of specific work activities

The FDNW Construction organization has a representative on the BWHC Zero Accident Committee at PFP. This committee meets monthly to assure that all safety concerns are adequately addressed and taken care of.

FDNW also has a representative at the BWHC Plan of the Day meeting to assure that the contractor is aware of all ongoing work within PFP and that proper safety precautions are taken. 


\subsection{FACILITY SAFETY ANALYSIS}

The facility safety analysis documentation for Project W-460 will be prepared in accordance with procedure HNF-PRO-703, Safety Analysis Process-New Project. A Preliminary Safety Evaluation (PSE) was prepared in parallel with W-460 CDR and released March 14, 1997, as document HNF-SD-W460-PSE-001. The PSE provides a safety analysis of the conceptual design to develop a preliminary list of safety class and safety significant SSC. The PSE assures that safety basis drivers are adequately factored in to the conceptual design scope, schedule, and estimate.

The Title I (Preliminary) design for Project W-460 was started in April 1998 based upon the original project scope to obtain an automated SPE via the DOE PuSAP national procurement action. A Criteria Document (CD) was drafted during this process in accordance with procedure HNF-PRO-705, Safety Basis Planning, Documentation, Review, and Approval. The current revision of the W-460 CD describes the required activities needed to develop safety analysis documentation in support of Project W-460. The CD provides stakeholders an opportunity to concur in the safety analysis activities being performed, the schedule, the cost, and the proposed format and content of the documentation.

During the Title I (Preliminary) design process, a draft PSAR was prepared by FDNW. This draft will require revision and additional development during Title II design to reflect adoption of an alternative SPE. The PSAR provides safety documentation to authorize the construction phase of the project.

An Addendum to the PFP Final Safety Analysis Report (FSAR) will be prepared to authorize operation of the project modifications. Assuming approval of Revision 1 to the PFP FSAR, a single FSAR Addendum for Project W-460 will be prepared during the construction phase of the project.

The safety analysis being performed by FDNW will be coordinated with the Fire Hazards Analysis being performed by Hughes Associates, Inc. This coordination will assure that a consistent approach to accident scenarios common to both analyses is used.

\subsection{SAFEGUARDS AND SECURITY}

Safeguards and security measures will be implemented during the execution phase of the construction activity as directed by FSP-PFP-5-8, "Plutonium Finishing Plant Administration," Element 4, and HNF-PRO-396, Planning Construction Projects in Security Areas.

\subsection{CONSTRUCTION SECURITY PLAN}

A construction security plan will be written for the project because construction activity will affect the physical security of the Material Access Area (MAA) inside the 
Protected Area (PA). Concurrence by Protection Technology Hanford and the Plant manager or designated representative is required for the Plan.

Construction fences and gates will be as described in the construction security plan.

\subsection{PHYSICAL PROTECTION OF PROPERTY AND FACILITIES}

Protection measures to prevent unauthorized access, damage or destruction arising from deliberate acts and to deter and prevent theft of government property will be as prescribed in FSP-PFP-5-8, Element 4. Entry to the PA and MAA is controlled by Hanford Patrol in accordance with DOE M 5632.1C-1, "Manual for Protection and Control of Safeguards and Security Interests," and HNF-IP-1065-PO22, Post Orders: Northern Area.

- A security point of contact appointed by the BWHC, FDH, or FDNW will coordinate construction security concerns with the Protection Technology Hanford Site Security Representative.

- Physical protection measures will be implemented in accordance with FSP-PFP-5-8, HNF-IP-1065-PO22, and the Construction Security Plan.

- End of day checks of the construction site and the affected portion of the material access area and protected area will be defined in the construction security plan.

- Access control to the protected area is already established per DOE M 5632.1C-1, FSP-PFP-5-8, and HNF-IP-1065-PO22.

- Access (entry) to the protected area and material access area is controlled by Hanford Patrol.

- Security badges will be worn in all site-affiliated locations, on the outer garment, above the waist, in the front of the body, unless the wearing of the badge would cause an unsafe working condition. In such instances, as soon as the safety condition is over, badges must be replaced in a visible location.

- Control of visits and visitors to the PFP protected area will be in accordance with FSP-PFP-508.

\subsection{CONFIGURATION CONTROL}

Project W-460 will require modification to an existing operating facility. Design and construction related activities will be conducted in accordance with the PFP Operational Configuration Management Program Plan, ZAP-000-002. As the design agent, FDNW will comply with the approved Facility Stabilization Project Execution Plan and Project Procedure Manual for Contract 651002 with BWHC to ensure that the design process will be controlled. 


\subsection{DOCUMENT AND RECORD MANAGEMENT}

As the performing contractor, BWHC will control project documents in accordance with HNF-PRO-232. BWHC will identify the requirements for documentation, record management, and document turn over to the project team participants. In addition, BWHC will identify the documents to be turned over to project files (LMSI/Document Control) at project completion. Other participating organizations will maintain project records in accordance with their company procedures.

\subsection{PROCEDURE/ PROCEDURE DEVELOPMENT}

BWHC Project W-460 will apply appropriate procedural instruments to ensure and promote communication and to provide adequate control for essential project elements. Project participants comprise of PHMC contractors, $\mathrm{OHC}$, and other contractors. The procedural instruments associated with the contract between BWHC and the participating subcontractors will include HNF PROs, subcontractor's procedures, and project specific procedures, as appropriate.

Project specific procedures will be developed and applied, if needed. In the event project specific procedures are required, a reference will be introduced in the PEP at the appropriate section. The reference will defer to an appendix that will be added to this document, where supporting documentation will be compiled in a section devoted to the affected participant. The appendix will be updated as the project progresses and procedures evolve.

An introduction to the procedures intended for the project is compiled for each project participant. Attention is directed to potential project specific procedures.

\subsection{FDNW}

All engineering, procurement, and construction work and the ancillary activities will be performed in accordance with FDNW Facility Stabilization Project documents that were effected by Facility Stabilization Project Contract 651002 or in accordance with HNF PROs imposed by specific contract task orders. FDNW Facility Stabilization Project documents were provided in response to the contract. The FDNW response to task order specific HNF PROs will be addressed in the FDNW response to the task order.

FDNW Facility Stabilization Project documents include the Facility Stabilization Project Execution Plan, Facility Stabilization Project Procedures Manual, Facility Stabilization Job Bulletins, Project Activity Plans, Task Specific Activity Plans, and FDNW Practices. These documents are resident on the Facility Stabilization local Intranet homepage. They are available to all Hanford Site personnel. The FDNW Facility Stabilization Project Director is responsible for control and revision of these documents. 
The Project Execution Plan defines the organization and systems for management of all Project work. It establishes the project management framework and procedures for execution of the project.

The Project Procedures Manual defines the work procedures needed to execute the project. It provides references to the standard company practices that will be used on the project.

The job bulletin provides specific information that is needed to perform work. It is a structured instrument that provides project management effective communication to project personnel. The job bulletin can be applied to provide information that is immediately needed to support project activities; it can be applied to supplement a document.

Project activity plans and task specific activity plans identify activities and the associated company and project specific practices that are applied to perform the work. As an example, the technical document control activity will have an activity plan.

Practices or procedures are the instruments that provide specific instruction for performing work such as Civil Engineering.

\subsection{PHMC CONTRACTORS}

All work and the ancillary activities that will be performed by PHMC major subcontractors will be performed in accordance with the HNF PRO series procedures.

\subsection{OTHER HANFORD CONTRACTORS}

All work and the ancillary activities that will be performed by the $\mathrm{OHC}$ will be performed in accordance the OHC's documents that will be effected by the BWHC contract or in accordance with HNF PROs imposed by specific contract task orders. The $\mathrm{OHC}$ documents will be provided in response to the $\mathrm{BWHC}$ contract. The $\mathrm{OHC}$ response to task order specific HNF PROs will be addressed in the $\mathrm{OHC}$ response to the task order.

\subsection{OTHER CONTRACTORS}

All work and the ancillary activities will be performed in accordance with the other contractor company's documents that will be effected by the BWHC W-460 Project contract or in accordance with HNF PROs imposed by specific contract requirements.

- The other contractor's documents will be provided in response to the contract. Their response to task order specific procedures will be addressed in the their response to the task order. 


\subsection{TRAINING}

Project training requirements will be identified in the contract between BWHC and the participating subcontractors. Training will include content particular to the participant contractor's required material and to project specific material, as appropriate.

Project specific training material will be developed and applied, if needed. In the event project specific training is required, a reference will be introduced in the PEP at the appropriate section. The reference will defer to an appendix that will be added to this document, where supporting documentation will be compiled in a section devoted to the affected participant. The appendix will be updated as the project progresses and training requirements evolve.

An introduction to the training intended for the project is compiled for each project participant. Attention is directed to potential project specific training.

\subsection{FDNW}

FDNW will establish a qualification and training program for FDNW personnel assigned to Project W-460. Training relevant to engineering, procurement, and construction work and the ancillary activities will be conducted in accordance with FDNW Facility Stabilization Project documents that were effected by Facility Stabilization Project Contract 651002 or in accordance with requirements imposed by specific contract task orders. The FDNW response to training required by task order will be addressed in the FDNW response to the task order. FDNW Facility Stabilization Project training requirements are identified in the Facility Stabilization Project Execution Plan, Facility Stabilization Project Procedures Manual, Facility Stabilization Job Bulletins, Project Activity Plans, Task Specific Activity Plans, and FDNW Practices.

The objective of the FDNW qualification and training program is to ensure that personnel are qualified and trained in project-specific methods and procedures needed for them to perform assigned tasks.

\subsubsection{Personnel Qualification}

FDNW personnel assignment to the project task force will be consistent with FDNW policy and will satisfy the requirements of 10 CFR 830.120 for nuclear facilities and DOE Order 5700.6C for non-nuclear and radiological facilities. Job positions with quality affecting task responsibilities will be identified. The minimum qualification requirements for these positions will be defined so that only qualified candidates will be assigned. 
24.1.2 Training Requirements and Documentation

The training requirements for project personnel will be based on the job category and on the tasks being performed. Qualification and training records will be maintained in the project files according to requirements of the project records retention schedule.

\subsection{PHMC CONTRACTORS}

PHMC contractors will establish a qualification and training program for their Project W-460 contract related activities. The PHMC contractor's training program will address project-related requirements in the HNF PROs.

\subsection{OTHER HANFORD CONTRACTORS}

Each $\mathrm{OHC}$ will establish a qualification and training program for their Project W-460 contract related activities. The training program will address requirements contained in the OHC's documents that will be effected by the BWHC contract or will address HNF PROs imposed by specific contract task orders.

\subsection{OTHER CONTRACTORS}

Each contractor will establish a qualification and training program for their Project $\mathrm{W}-460$ contract related activities. The training program will address requirements contained in the contractor's documents that will be effected by the BWHC contract or will address HNF PROs imposed by specific contract task orders. 


\section{APPENDIX A}

\section{W-460 PROJECT SCHEDULE}

Appendix A provides a more detailed project schedule to supplement the summary level schedule objectives information in Element 7.2. 


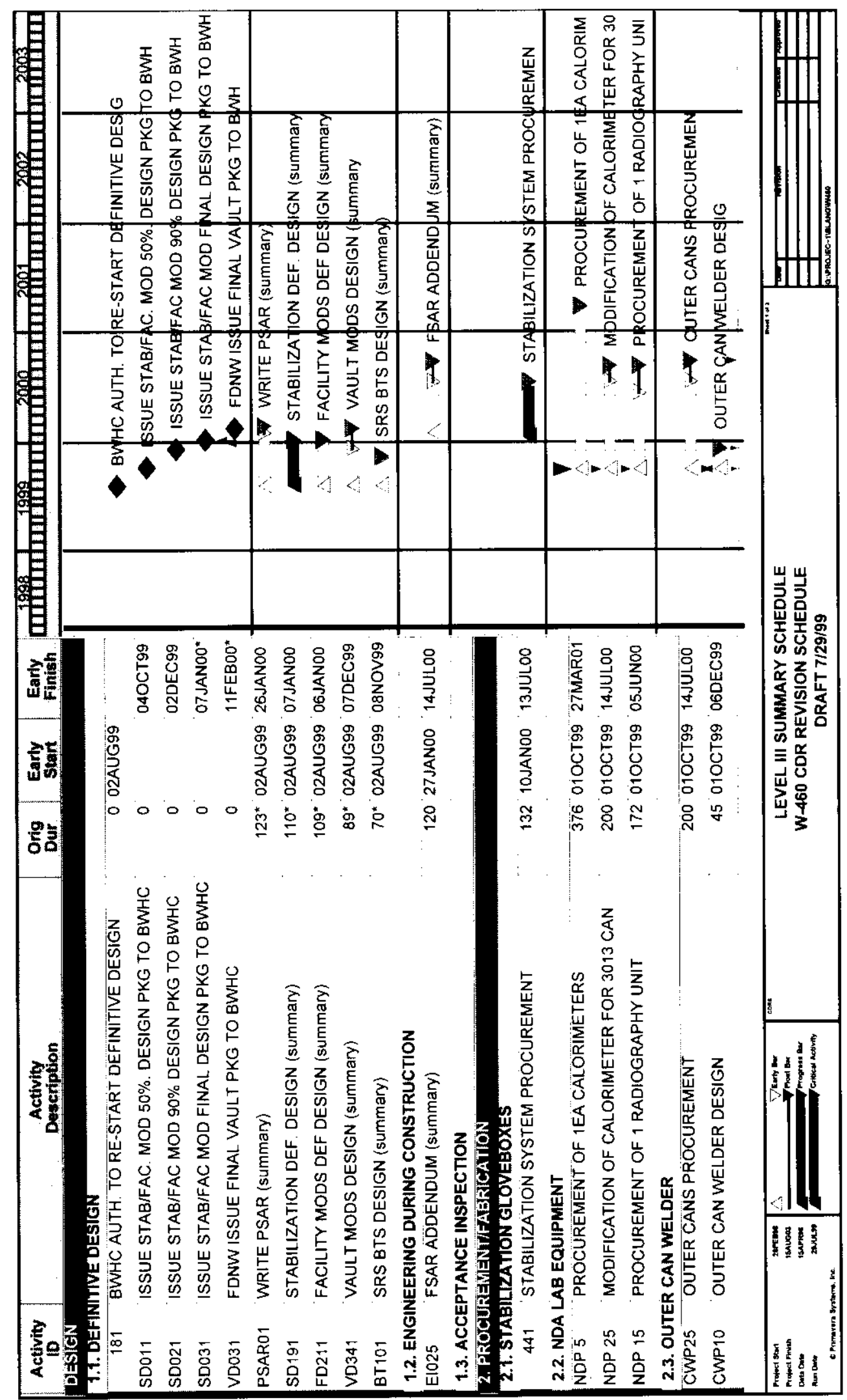




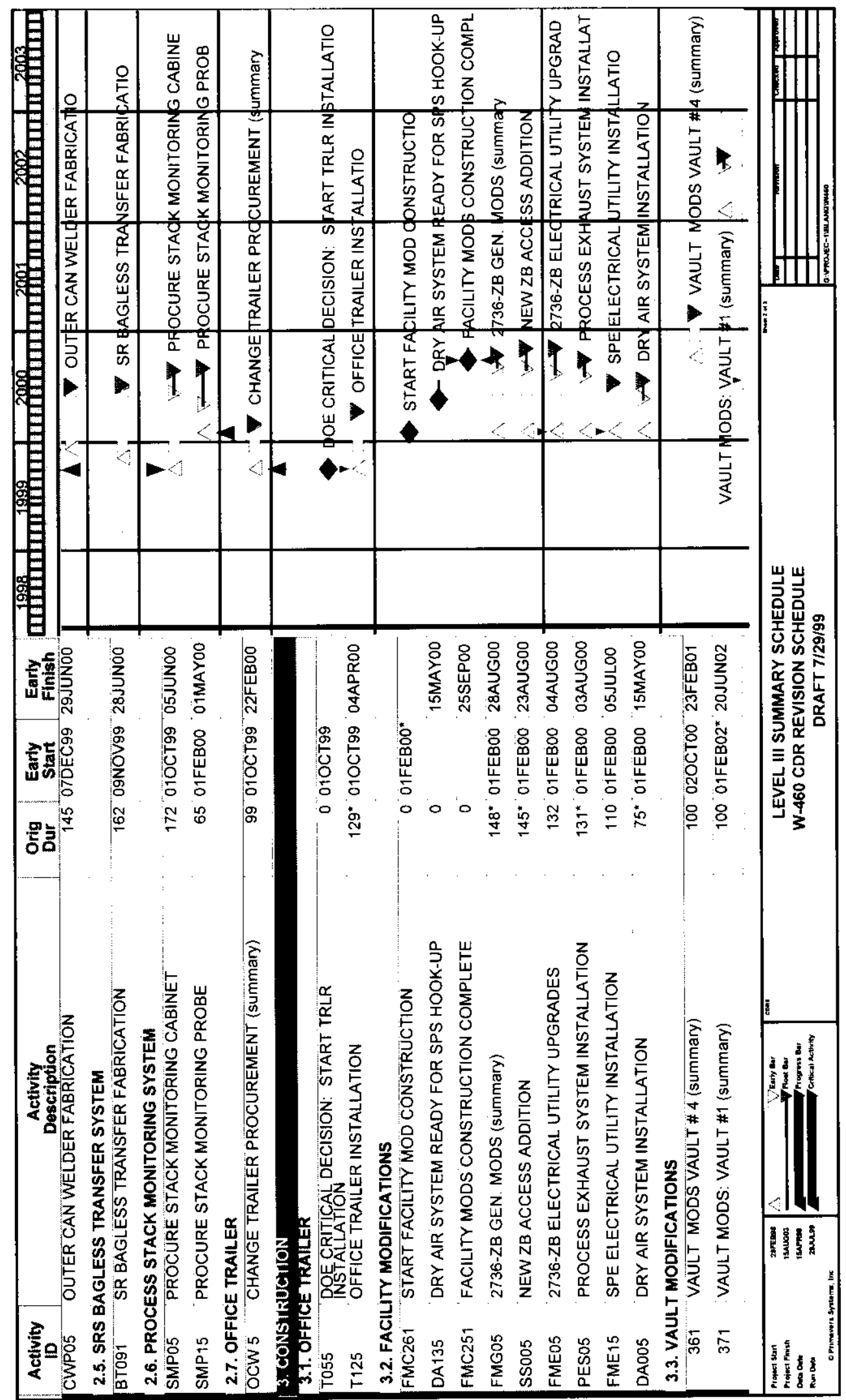




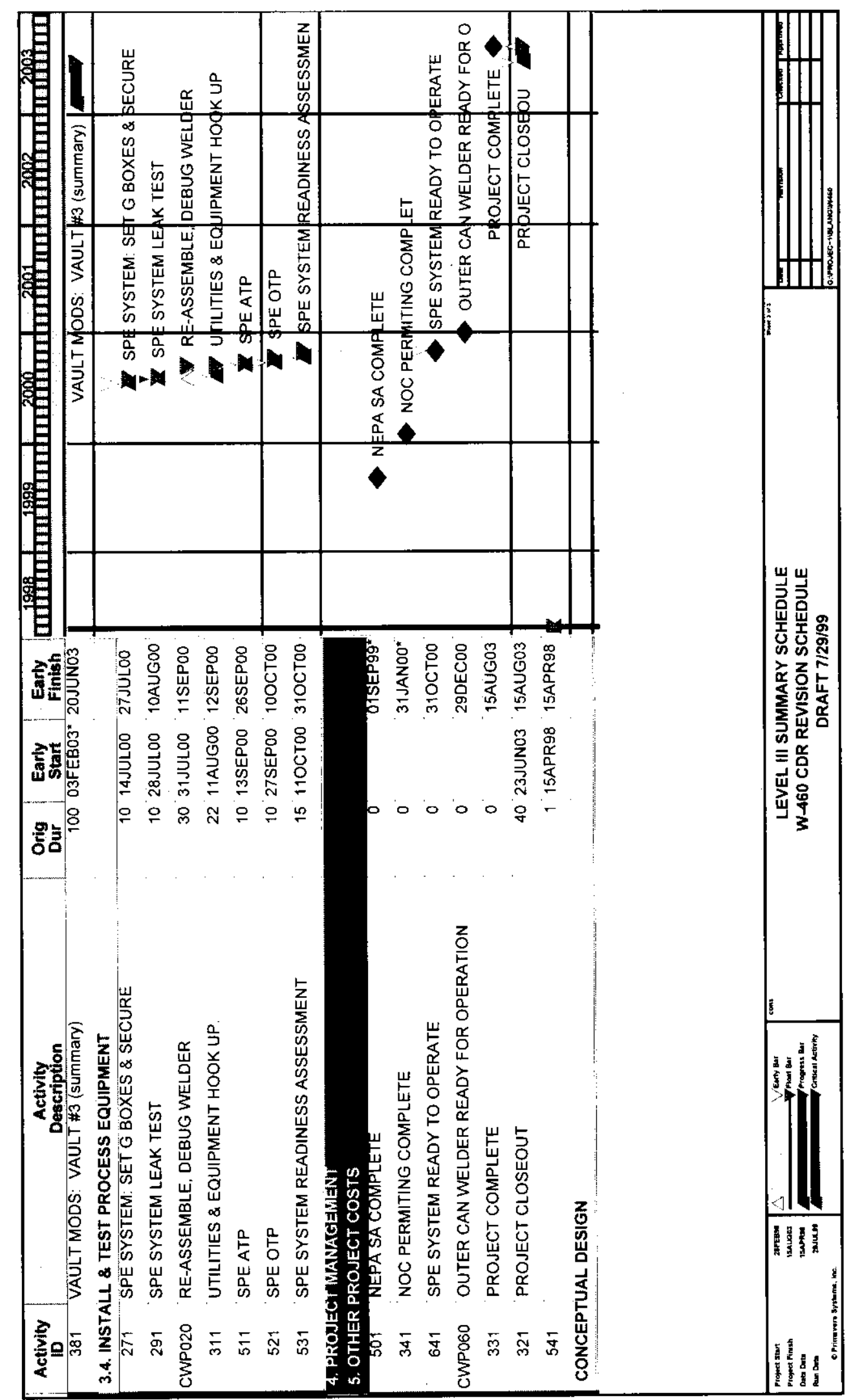




\section{APPENDIX B}

\section{BWHC SCHEDULE OBJECTIVES, \\ TOTAL ESTIMATED COSTS}

$\boldsymbol{\&}$

\section{CRITICAL DECISIONS}

Element 7 
Table B-1 - BWHC Schedule Objectives 1

\begin{tabular}{|c|c|c|c|}
\hline $\begin{array}{c}\text { WBS } \\
\text { Element }\end{array}$ & WBS Activity & Start & Complete \\
\hline 1.0 & Engineering & & \\
\hline 1.121 & Definitive Design (PuSAP) & $4 / 98$ & $2 / 99$ \\
\hline 1.122 & Facility Mod Design & $8 / 99$ & $1 / 00$ \\
\hline 1.130 & Vault Mod Design & $8 / 99$ & $2 / 00$ \\
\hline 1.140 & SPE Design & $8 / 99$ & $1 / 00$ \\
\hline 1.150 & Safety Analysis (PSAR) & $8 / 99$ & $2 / 00$ \\
\hline 1.200 & Engineering During Construction & Note 1 & Note 1 \\
\hline 1.300 & Acceptance Inspection & Note 1 & Note 1 \\
\hline 2.0 & Procurement Nôte 2 & & \\
\hline 2.10 & Stabilization Gloveboxes & $1 / 00$ & $8 / 00$ \\
\hline 2.22 & Calorimeter $-1^{\mathrm{st}}$ Unit (surplus) & $10 / 99$ & $7 / 00$ \\
\hline & Calorimeter $-2^{\text {nd }}$ Unit & $10 / 99$ & $1 / 01$ \\
\hline 2.23 & Radiography Equipment & $10 / 99$ & $4 / 00$ \\
\hline 2.24 & NDA Can Handling Equipment & $1 / 00$ & $3 / 00$ \\
\hline 2.30 & Outer Can Welder & $8 / 99$ & $6 / 00$ \\
\hline 2.40 & Change Trailer & $10 / 99$ & $2 / 00$ \\
\hline 2,50 & SRS BTS Equipment & $6 / 99$ & $6 / 28 / 00$ \\
\hline 2.60 & Stack Monitoring Equipment & $8 / 99$ & $5 / 00$ \\
\hline 3.0 & Construction & & \\
\hline 3.1 & Office Trailers & $10 / 99$ & $4 / / 00$ \\
\hline 3.2 & Facility Modifications & $2 / / 99$ & $9 / 00$ \\
\hline 3.3 & Vault Modifications - $1^{\text {st }}$ Vault & $10 / 00$ & $2 / 01$ \\
\hline & Vault Modifications $-2^{\text {nd }}$ Vault & $2 / 02$ & $6 / 02$ \\
\hline & Vault Modifications $-3^{\text {rd }}$ Vault & $2 / 03$ & $6 / 03$ \\
\hline 4.0 & Project Management ${ }^{\text {Note } 3}$ & $4 / 98$ & $8 / 03$ \\
\hline 5.0 & Other Project Costs & Note 4 & Note 4 \\
\hline \multicolumn{2}{|c|}{ Operational Objectives } & & \\
\hline \multicolumn{2}{|c|}{ 1. Ready to Start 3013 Packaging Operations } & $10 / 00$ & the \\
\hline 2. Read & to Start Stabilization in $2736-\mathrm{ZB}$ & $1 / 01$ & 13 \\
\hline \multicolumn{4}{|c|}{$\begin{array}{l}\text { 1. Engineering During Construction and Acceptance Inspection activities will be directly } \\
\text { related to all construction activities. } \\
\text { 2. Procurement start and complete dates reflect the start of the procurement action with } \\
\text { the finish date reflecting delivery of the item. } \\
\text { 3. The complete date for Project Management final project closeout. } \\
\text { 4. Other Project Costs are ongoing activities for the life of the project. }\end{array}$} \\
\hline
\end{tabular}


Table B-2 - Total Estimated Costs

\begin{tabular}{|c|c|c|c|c|}
\hline WBS & WBS Activity & $\begin{array}{c}\text { Estimated } \\
\text { Cost } \\
\text { (With } \\
\text { Escalation and } \\
\text { Site } \\
\text { Allocations) } \\
\end{array}$ & Contingency & $\begin{array}{l}\text { Total } \\
\text { Cost }\end{array}$ \\
\hline 1.0 & Engineering & & & \\
\hline 1.1 & Definitive Design & $\$ 5,070,000$ & $\$ 520,000$ & $\$ 5,590,000$ \\
\hline 1.2 & Engr. During Construction & $1,300,000$ & 190,000 & $1,490,000$ \\
\hline 1.3 & Acceptance Inspection & 180,000 & $\$ 20,000$ & 200,000 \\
\hline \multicolumn{2}{|r|}{ Subtotal Engineering } & $\$ 6,550,000$ & $\$ 730,000$ & $\$ 7,280,000$ \\
\hline 2.0 & Procurement & & & \\
\hline 2.1 & Stabilization Equipment & $\$ 1,820,000$ & $\$ 540,000$ & $\$ 2,360,000$ \\
\hline 2.2 & NDA Laboratory Equip. & $1,240,000$ & 70,000 & $1,310,000$ \\
\hline 2.3 & Outer Can Weld System & $3,090,000$ & 470,000 & $3,560,000$ \\
\hline 2.4 & Change Trailer & 48,000 & 2,000 & 50,000 \\
\hline 2.5 & SRS BTS Equipment & $2,540,000$ & 250,000 & $2,790,000$ \\
\hline 2.6 & Stack Monitoring Equip. & 180,000 & 20,000 & 200,000 \\
\hline \multicolumn{2}{|r|}{ Subtotal Procurement } & $\$ 8,918,000$ & $\$ 1,352,000$ & $\$ 10,270,000$ \\
\hline 3.0 & Construction & & & \\
\hline 3.1 & Office Trailers & $\$ 610,000$ & $\$ 80,000$ & $\$ 690,000$ \\
\hline 3.2 & Facility Modifications & $5,030,000$ & $1,070,000$ & $6,100,000$ \\
\hline 3.2 & Vault Modifications & $6,690,000$ & $2,210,000$ & $8,900,000$ \\
\hline \multicolumn{2}{|r|}{ Subtotal Construction } & $\$ 12,330,000$ & $\$ 3,360,000$ & $\$ 15,690,000$ \\
\hline 4.0 & Project Management & $\$ 2,590,000$ & $\$ 270,000$ & $\$ 2,860,000$ \\
\hline \multicolumn{2}{|c|}{ Total Estimated Construction Cost } & $\$ 30,388,000$ & $\$ 5,712,000$ & $\$ 36,100,000$ \\
\hline 5.0 & Other Project Costs (expense) & $\$ 4,890,000$ & $\$ 210,000$ & $\$ 5,100,000$ \\
\hline & Total Project Cost & $\$ 35,278,000$ & $\$ 5,922,000$ & $\$ 41,200,000$ \\
\hline
\end{tabular}




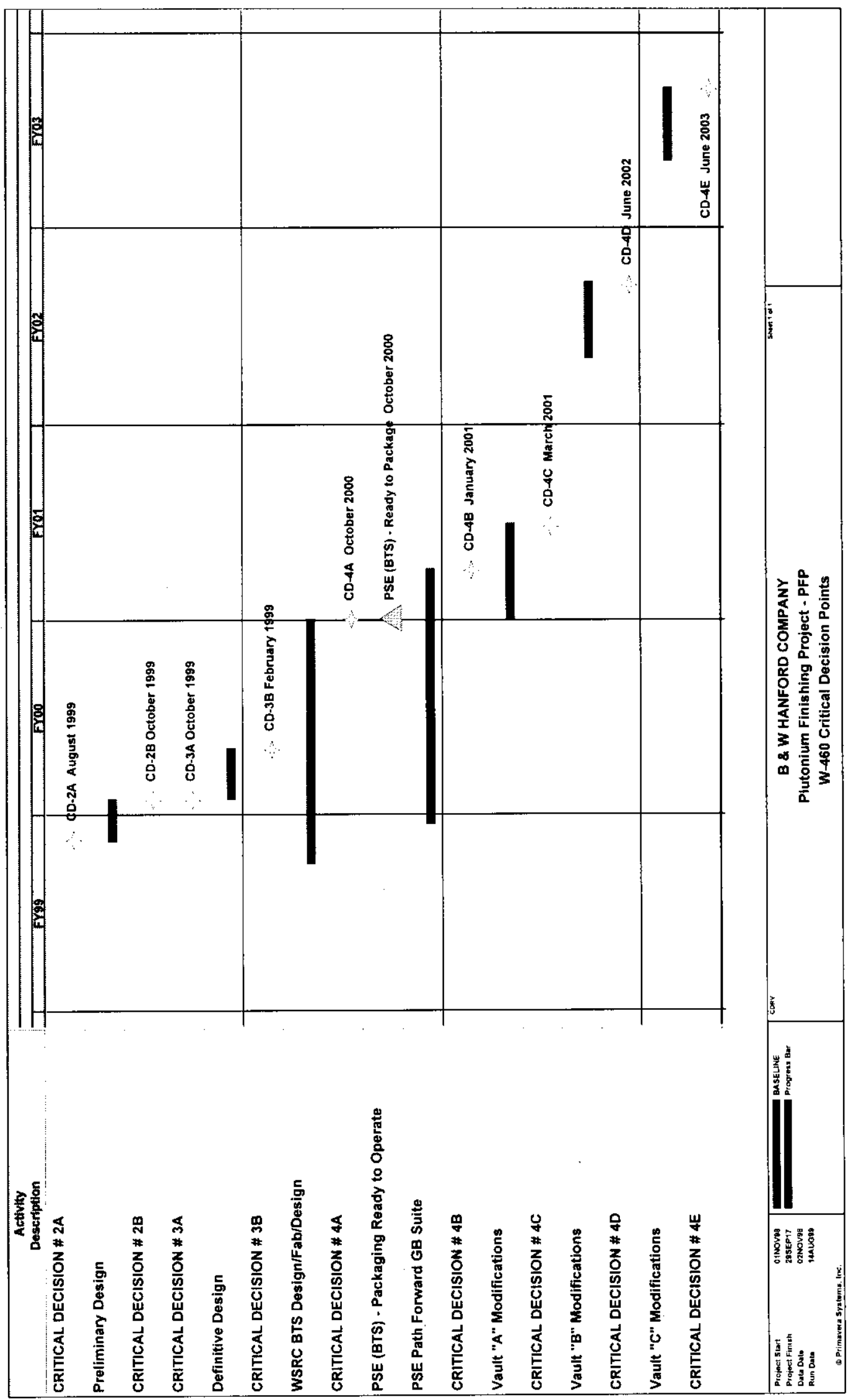




\section{Critical Decisions}

CD-2A Upon completion of Validation For long lead items including BTS GB, Stabilization GBs, BTS System, Outer Can Welder, and other long lead items affecting the stabilization or packaging process.

CD-2B Upon completion of preliminary design for the remainder of the project.

CD-3A Upon completion of design of the CD-2A items

CD-3B Upon completion of the design covered under CD-2B

CD-4A Operational Readiness of the packaging systems (BTS and OCW)

CD-4B Operational Readiness of the Stabilization Process

CD-4C Beneficial use of the 1s tModified Vault

CD-4D Beneficial use of the 2nd Modified Vault

CD-4E Beneficial use of the 3rd Modified Vault 


\section{APPENDIX C}

\section{PuSH Project W-460 \\ Organization Chart}




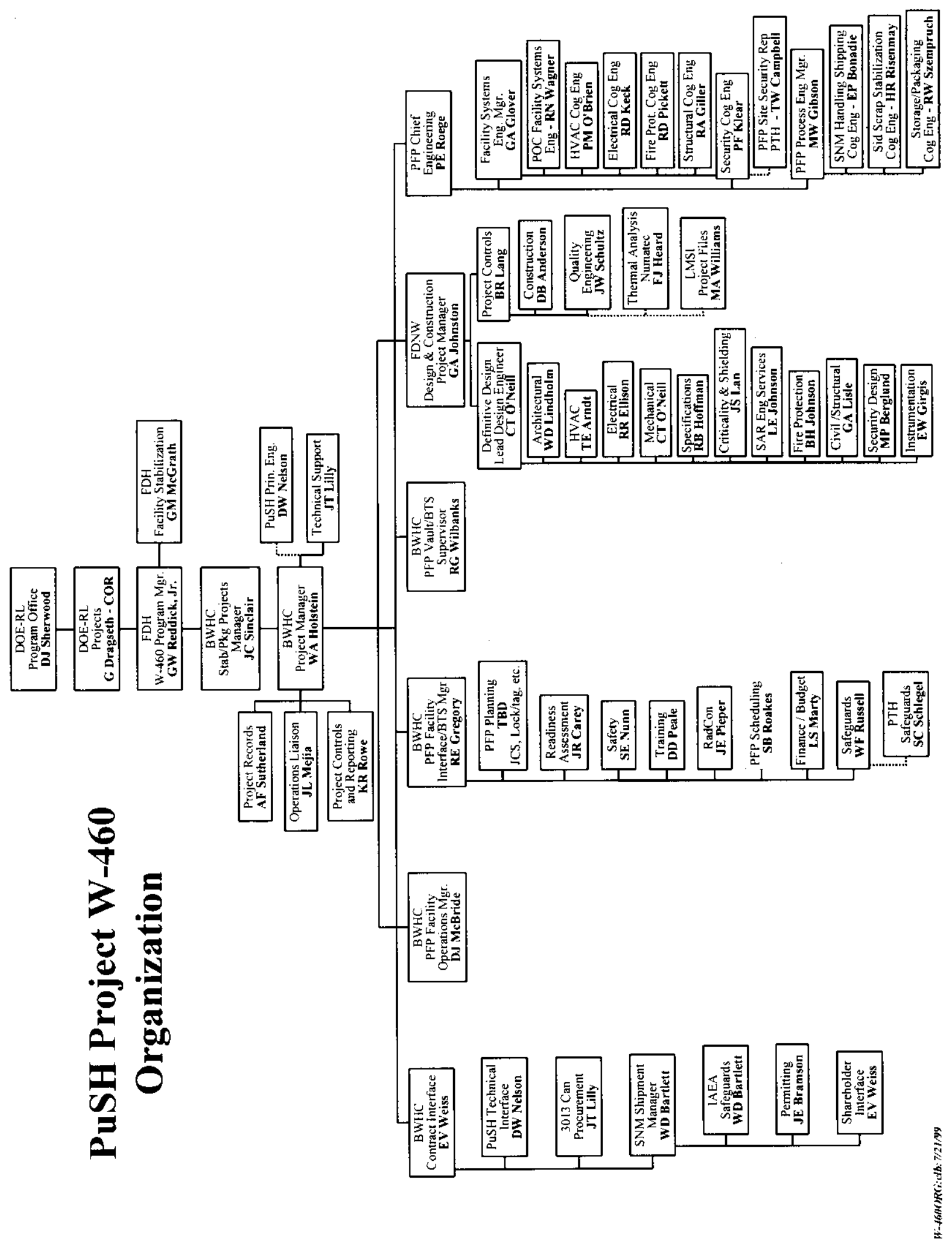


THIS PAGE INTENTIONALLY

LEFT BLANK 


\section{APPENDIX D}

\section{MEMORANDUM OF UNDERSTANDING \\ Between WSRC and BWHC}


Mr. L.J. Olguin, Projer̂t Djreclur

Fucidity Stabilization Project

Fluor Daciel Hanford, lic. [ $\quad \overline{5}-65$

Pust Office BOX 1000

Richland, Washington 99352-1000

Deăr Mr. Olguin;

Eneloged for your inlorration is the approved Memorandum of Understansling (MOL), revision O, Fot the Hanford Baigless Transfer System. The uesecenent has been rcviewed and approved by B\&W Hanford Company (BWHC). Fluor Daniel Hanford, ]ac. (JPC), Westinghouse Savannah River Company [WSRC), the U.S. Depertinent of Energy, Richland (Operations Office (RL) atud the U.S. Deparment of Encrey, Satannah River Operaljons Office (SR).

AuHC is pleased to haye at integral role in pursuing inter-sice technology transfer through use of the "bagless trens fer systern" developed for Savannah River Site. If you need more informaliug p'casc contact J.C. Sincihje IJI (509-373-7353) ar W.A. Hoislcir $(509 \cdot 372 \cdot 0114)$.

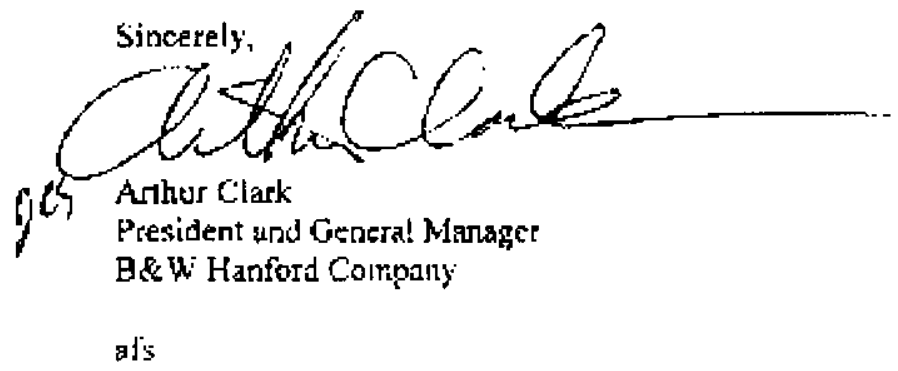

Atlachnont 


\title{
MEMORANDUM OF UNDERSTANDING FOR SUPPLY OF A BAGLESS TRANSFER SYSTEM FOR THE PLUTONIUM FINISHING PLANT
}

\author{
Revision 0
}

June 1999 


\section{APPROVALS:}

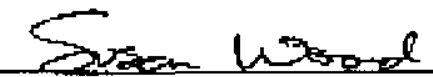

$6-24-94$

Dr. S. Wond, Vice President and Director,

Date

Savananh River Technology Center

Westinghouse Savannali River Company
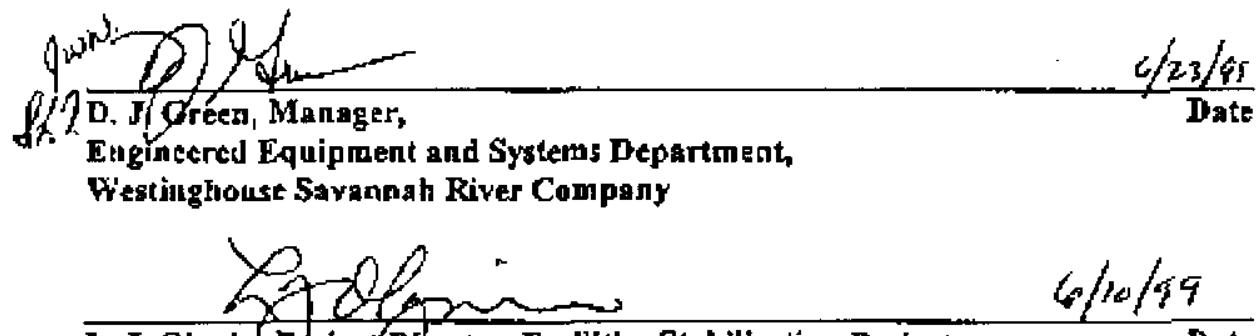

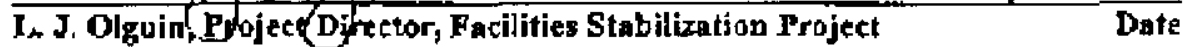

Fluor Daniel Hanford, Ine.

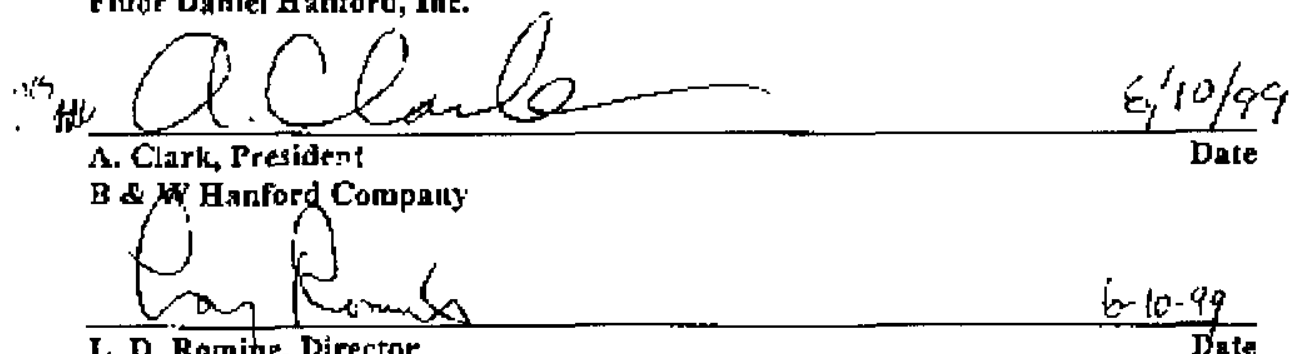

L D. Romine, Director

Ijate

Transition Programs Divisian

Departicent of Energy, Richland Operations OTite

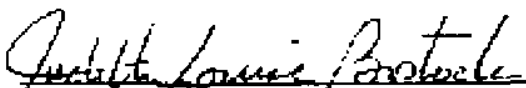

J.l. Bustbck, Asgletant Hegger science and Techholosy Juvtsion

lepartment of Eoergy. Saveosah R1ver Site 


\subsection{Introduction}

\subsection{Purpose of MOU}

The purpose of this Memorandum of Understanding (MOU) is to formally establish responsibilities and requirements to affect the acquisition of a Bagless Transfer System (BTS) for packaging of plutonium in welded containers from Westinghouse Savannah River Company (WSRC) for installation in the Hanford Plutonium Finishing Plant (PFP). An Interoffice Work Order (IWO) between the Department of Energy - Richland Operations Office (RL) and the Savannah River Operations Office (SR) will be prepared and mutually approved which will function as a companion document to fund the efforts of WSRC as outlined in this MOU.

The WSRC will provide design, fabrication, testing and technical support for the BTS. B\&W Hanford Company (BWHC) will install the equipment and provide final operational testing. Fluor Daniel Hanford, Inc (FDH), as the Management and Integration Contractor at Hanford, will provide project oversight. The key Points of Contact for this task are shown in the Attachment.

To the extent that any provision of this MOU is inconsistent with or imposes obligations that differ from the terms of either a) Contract No. DE-AC06-96-RL 13200 between FDH and RL, b) Subcontract No. 80232764-9-K002 between FDH and B\&W Hanford Company, or c) Contract No. AE-AC09-96-SR 18500 between WSRC and SR, the terms of such contracts shall prevail.

\subsection{Purpose of Task}

The work outlined in this MOU will provide equipment, associated instrumentation and controls for packaging Special Nuclear Material (SNM) into welded stainless steel containers at PFP without the use of any organic seals and without the use of traditional "bagout" methods. The equipment to be acquired will be identical to existing equipment now operating at the SRS FB Line with the exception of BWHC-directed changes. The equipment, documentation and technical support will be supplied by the Engineered Equipment \& Systems Department (EES) of WSRC.

\subsection{Background Information}

In order to comply with the criteria in DOE Technical Standard DOE-STD-3013-96, Hanford must acquire the technology to seal SNM into a welded container that has a contamination-free exterior surface without the use of elastomeric seals. The resulting cans must also meet PFP vault storage requirements. Technology developed and currently in operation in the FB Line at the Savannah River Site has the needed characteristics to accomplish this goal. This equipment will be acquired as part of Hanford Project W-460. 


\subsection{Scope of Work}

The WSRC shall provide all design services, engineering calculations, technical support, labor and materials for fabrication of equipment, supplies, procedures and manuals necessary to

- supply an FB Line BTS including any BWHC-directed changes,

- fabricate and assemble BTS equipment and controls in an enclosure to be provided by BWHC,

- $\quad$ shop test the BTS and controls,

- $\quad$ and provide technical assistance during installation, testing, and demonstration of BTS operability at the PFP.

WSRC shall also provide design services, engineering calculations, technical support, labor and materials for fabrication of equipment, supplies, procedures and manuals necessary to

- Modify the height of the existing Bagless Transfer Can ("Tall BTC"), qualify the can to meet DOE-STD-3013-96 criteria for inner welded cans and PFP vault storage requirements,

- $\quad$ Procure short and tall BTC cans and plugs for shop testing, acceptance testing and initial PFP operations.

WSRC shall provide to BWHC technical and procurement documentation generated in this effort, in both approved hard copy and electronic form. At a minimum, the following types of documents shall be provided:

- Design analyses as appropriate (calculations and determinations which support the final design)

- Vendor data

- Design media (drawings, documents and electronic files)

- Equipment specifications

- Control software code listings and support documentation

\subsection{Update BTS Design}

The design of the PFP BTS shall be identical to the SRS FB Line system as it is configured on May 1, 1999, however, changes may be directed to the design of the PFP BTS as provided in Section 5.2. 


\subsection{Equipment to be provided by WSRC}

\section{WSRC shall provide the following equipment:}

- Bagless Transfer Unit

- welder, weld controller, recorder and recorder cabinet

- $\quad$ welded can cutter

- $\quad$ sphincter seal

- Helium backfill assembly and valvebox

- $\quad$ frame to support the BTS

- $\quad$ loading arm and tool arm

- Consumables: tungsten tips, cutter wheels, sphincter seal, change out blanks, etc

- To support shop testing at SRS

- To support operability testing at PFP

- To support initial operations at PFP (tips and wheels only)

- Operator station with software

- Two cameras for process monitoring

- Control cabinet

- Can rework cutter

- Wiring and control cabling

- Glycol cooled weld cable

- Junction box for control cabling

- Leak detector with two bell jars and calibration aids

- Special tools for sphincter seal change out

- Alignment tools

- Special tools for off-normal weld conditions

- Vacuum pump

\subsection{Equipment and Services to be provided by BWHC}

BWHC shall supply the following equipment and information:

- Glovebox and enclosure, modified to accept BTS,

- Facility layout drawings for interface and services,

- Project W-460 documentation such as functional design criteria and technical analyses, and

- Electrical, HVAC and process gas services.

\subsection{Technical Support}


- WSRC will provide onsite staff at Hanford to assist with:

- Installation of BTS equipment

- Acceptance and operability testing, and

- Follow-on technical support during the startup period.

An estimate of on-site duration and staffing levels for this support will be included in preliminary and final task estimates (see Section 5.1).

- WSRC will assist BWHC by reviewing project W-460 documentation for consistency with equipment design.

- WSRC will generate video footage of assembly tasks as carried out in the WSRC Shops for use in maintenance training.

- BWHC will provide engineering, operations, maintenance and quality assurance support during fabrication, assembly, and shop testing of the BTS at SRS for familiarization and orientation, and to perform specific witness inspections. RL may at its discretion also witness inspections. WSRC will notify RL and BWHC approximately two weeks in advance of pending inspections to allow representatives to attend.

\subsection{Design, Test and Fabricate Bagless Transfer Cans (BTC)}

- Tall BTC

- WSRC will modify the design of the existing short BTC to optimize the height within a "3013" outer can envelope per specific criteria to be supplied by BWHC.

- $\quad$ BWHC and WSRC will jointly determine a testing regime to qualify the tall BTC for use as an SNM storage container in the Hanford vaults. WSRC will prepare, submit for BWHC approval and execute a Fabrication/Inspection/Test (FIT) Plan for this effort.

- $\quad$ BWHC and WSRC will jointly test tall BTCs per the qualification testing regime mentioned above.

- WSRC will procure tall BTC components per the table below to support qualification testing and shop testing of the BTS at SRS, plus operability testing and initial operation at PFP.

- WSRC will provide design media, equipment specifications, test results and a recommended weld procedure for this can.

- Short BTC

- WSRC will procure short BTC components in amounts (per the table below) per existing drawings for use in BTS equipment qualification testing at SRS and Hanford, and for initial operation at PFP.

- $\quad$ BWHC will verify that the existing short BTC qualification allows it to be used as a storage container in the PFP vaults. 


\begin{tabular}{|l|l|l|}
\hline \multicolumn{2}{|c|}{ CANS TO BE PROVIDED BY WSRC } \\
\hline \multicolumn{1}{|c|}{ CAN USE: } & \multicolumn{2}{c|}{ CAN TYPE } \\
\hline & \multicolumn{2}{|c|}{ TALL BTC } \\
\hline $\begin{array}{l}\text { Qualify Can at SRS for PFP } \\
\text { Vault Storage (drop test) }\end{array}$ & 10 & 0 \\
\hline $\begin{array}{l}\text { Test at SRS to meet "3013" } \\
\text { criteria (drop test, etc) }\end{array}$ & 10 & 0 \\
\hline BTS Shop Test at SRS & 50 & 50 \\
\hline BTS Demo at PFP & 50 & 50 \\
\hline Initial Operations at PFP & 150 & 150 \\
\hline & & 250 \\
\hline
\end{tabular}

\subsection{Potential Additional Tasks}

WSRC will provide conceptual estimates for the following items to assist BWHC in early decision making. Detailed criteria and costing information will be prepared only if specifically requested by BWHC in accordance with project needs and timing. Any addition of tasks into the scope of work will be authorized in writing per Section 5.2.

- Design and testing of convenience cans to fit into both the short and tall BTC. Fabrication of convenience cans in the same quantities as the associated inner cans for testing and initial operations.

- Execution of BTS glovebox modifications including shielded enclosure

\subsection{Assumptions}

\subsection{Technical Assumptions and Approach}

Detailed technical requirements are contained in the Functional Design Criteria (FDC) for Project W-460 to be provided to WSRC by BWHC. Key technical assumptions are listed below for reference:

- The BTS will be used to package both plutonium metal forms and oxides; all material will enter the BTS enclosure contained within a convenience can. 
- Design changes from the existing FB Line system will be minimized in order to expedite implementation of the BTS at PFP. BWHC approval is required only for those specific elements that differ from the FB Line design.

- Use of the convenience cans will have minimal impact on the BTS design and operation, or on the outer can.

- The existing DOE-STD-3013-96 qualification for the short BTC will be the basis for qualification of the tall BTC for storage at PFP and for compliance with the criteria in DOE-STD-3013-96.

- The BTS as designed for SRS FB Line will not require modification specifically to meet seismic criteria for Hanford.

- The BTS as designed for SRS FB Line meets safety criteria for General Service items. Design changes may be necessary if any portion of the BTS is required to meet Safety Significant or Safety Class requirements per the Project W-460 Functional Design Criteria and Quality Assurance Program Plan.

\subsection{Programmatic Assumptions and Approach}

Key programmatic assumptions related to implementation of the BTS at Hanford include:

- All formal review cycles will be 10 calendar days maximum.

- Sufficient funding for FY 1999 tasks and first quarter FY 2000 tasks by WSRC will be received at SR by June 1, 1999. Funding for WSRC FY2000 tasks will be made available at the earliest opportunity once RL receives the project funding.

- A BTS-ready glovebox, qualified to meet Hanford seismic criteria once installed, will be available at SRS by January 1, 2000.

- The design for the outer 3013 container will be the existing "BNFL" version, for which WSRC is the design agent.

\subsubsection{Interface with Project W-460 Design Criteria documentation}

BWHC and WSRC will coordinate the production of design media to allow electronic transmission where possible. BWHC will provide an updated copy of the Project W-460 Functional Design Criteria (FDC) to WSRC as soon as that document is updated to reflect inclusion of the BTS in the project. The FDC contains criteria applicable to all elements of Project W-460 including the BTS. [Note: BWHC previously provided a copy of the existing document to WSRC for early information.]

\subsection{Schedule}

WSRC will provide a preliminary schedule for all BTS work including options within 15 working days from receipt of initial funding from RL. All assumptions made for generation of the preliminary schedule will be attached, including anticipated safety/functional classification (critical characteristics). BWHC, FDH and RL will review and approve the schedule within 10 working days. WSRC will include identification of critical points for review and approval, such as approval 
of final design prior to fabrication. This assumes substantial agreement on the intent of the BTS Quality Assurance Plan (QAP) and this MOU.

BWHC will provide to WSRC preliminary safety classification for all structures, systems and components included in the BTS within 5 working days after receipt of initial funding at WSRC. BWHC will provide to WSRC a preliminary determination of required can dimensions in the same transmittal.

WSRC will provide a final detailed schedule for all BTS work within 10 working days after approval of the QAP. BWHC, FDH and RL will review and approve the schedule within 10 working days.

\subsection{Milestones}

WSRC and BWHC will agree upon all milestones as part of approval for the schedule discussed above, based on the programmatic assumptions contained in this MOU.

ACTIONEE ACTION

FDH/RL Delivery of initial funding and authorization to WSRC

WSRC Delivery of BTS to Hanford
TARGET DATES

June 1, 1999

May 31,2000

\subsection{Funding}

An Interoffice Work Order (IWO) between RL and SR will be prepared and mutually approved which will function as a companion document to this MOU. Initial funding will be provided to WSRC by June 1, 1999 to permit timely preparation of a cost estimate and schedule for delivery of the BTS. The initial funding will also permit development of a Project Management Plan (PMP) and QAP.

\subsection{Cost Estimates}

WSRC EES will prepare a preliminary detailed cost estimate for delivery of the BTS plus the various options described in this document. All assumptions made for generation of the preliminary cost estimate will be attached, including anticipated safety/functional classification (critical characteristics). The cost estimate will be provided to RL within 15 working days of receipt of funds and authorization to proceed with planning. This assumes substantial agreement on the intent of the QAP and this MOU. WSRC will provide a final cost estimate within 10 working days after approval of the QAP. 


\subsection{Assumption of Financial Risk}

FDH, BWHC and WSRC will not proceed with any action that has not been authorized in writing by the PFP Senior Program Manager, Mr. J.C. Sinclair III or designee (current designee is Ms. Evelyn Weiss). Mr. Sinclair will function as the designated formal point of contact (POC) for BWHC and Contracting Officer's Technical Representative (COTR) for this task.

\subsection{Project Control and Measurement}

A detailed PMP will be developed by WSRC and approved by BWHC for this task. The PMP will contain controls for changes to scope, schedule, and cost. The plan will also discuss roles and responsibilities for the EES and W-460 project organizations. Configuration control of the MOU will be maintained by the BWHC COTR. Configuration of changes to design drawings and equipment will be maintained by WSRC. The PMP will comply with WSRC and BWHC procedures

Because timing is critical for this effort, BWHC review comments on BTS design drawings and documents must be obtained and returned to WSRC within 10 calendar days of receipt.

WSRC will provide to the BWHC COTR a written monthly report that discusses progress on the project, issues which require mutual resolution and corrective actions to remediate schedule slippage. A teleconference between Savannah River and Hanford staff will be held at least biweekly to provide updated project status. Informal dialogue at the working level is encouraged to interface frequently to discuss and resolve issues as they arise, within the limits discussed in Section 5.2 above.

No changes to the work scope described in this MOU will be implemented without the written approval of the BWHC COTR and RL.

\subsection{Quality Assurance Plan}

WSRC will prepare and BWHC will approve a Quality Assurance Plan for the BTS project by June 30,1999 , subject to receipt of preliminary safety classification and can size information as mentioned above. The QAP will comply with WSRC and BWHC procedures, and be based on elements of the PMP discussed above.

WSRC will prepare and BWHC will approve an Inspection/Acceptance Plan for the equipment to be provided by WSRC. The plan will comply with the above-mentioned QAP. WSRC will notify RL and BWHC of pending inspections approximately two weeks in advance to allow participation if desired. FDH will visit WSRC for the purpose of establishing quality assurance program capabilities to add WSRC to the FDH Evaluated Suppliers List (ESL) to support this effort. 


\subsection{References}

This effort will be governed by applicable codes and standards, and DOE Orders, as cited in the Project W-460 Functional Design Criteria Document.

\subsection{Applicable Rules and Regulations}

In any case where the site rules and regulations which apply to the work of RL, SR, WSRC, FDH and BWHC conflict, a resolution shall be jointly arrived at and approved by all parties. 


\title{
ATTACHMENT \\ TO \\ MEMORANDUM OF UNDERSTANDING \\ FOR SUPPLY OF A BAGLESS TRANSFER SYSTEM \\ FOR THE PLUTONIUM FINISHING PLANT
}

\author{
Revision 0
}




\section{HANFORD/SRS BTS PROJECT CONTACTS}

\begin{tabular}{|c|c|c|c|c|c|}
\hline STMU & COMTHE & 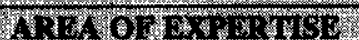 & TM12110\% & Fter & DMre \\
\hline $\begin{array}{l}\text { George Reddick } \\
\text { G. W. }\end{array}$ & FDH & 94-1 Program Manager & $509-376-2326$ & $509-376-6112$ & George_W_Jr_Reddick@rl.gov \\
\hline $\begin{array}{l}\text { George McGrath } \\
\text { G. M. }\end{array}$ & $\mathrm{FDH}$ & Program Support & $509-376-8819$ & $509-376-6112$ & George_M_Jr_McGrath@rl.gov \\
\hline $\begin{array}{l}\text { John Sinclair } \\
\text { J. C. }\end{array}$ & BWHC & Senior Program Manager & $509-373-7353$ & $509-373-4274$ & John_C_Sinclair@RL.gov \\
\hline $\begin{array}{l}\text { Tim Huber } \\
\text { T. E. }\end{array}$ & BWHC & $\begin{array}{c}\text { Trans Engineering } \\
\text { Manager }\end{array}$ & $509-373-1503$ & $509-373-2603$ & Timothy_E_Huber@RL.gov \\
\hline $\begin{array}{l}\text { Evelyn Weiss } \\
\text { E. V. }\end{array}$ & BWHC & Program Manager & $509-372-1109$ & $509-376-9202$ & Evelyn_V_Weiss@RL.gov \\
\hline $\begin{array}{l}\text { Bill Holstein } \\
\text { W. A. }\end{array}$ & $\mathrm{BWHC}$ & W-460 Project Manager & $509-372-0114$ & $509-376-9202$ & William_A_Holstein@RL.gov \\
\hline $\begin{array}{l}\text { Darryl Nelson } \\
\text { D. W. }\end{array}$ & BWHC & Lead Project Engineer & $509-373-2841$ & $509-376-9202$ & Darryl_W_Nelson@RL.gov \\
\hline $\begin{array}{l}\text { Mark Gibson } \\
\text { M. W. }\end{array}$ & BWHC & $\begin{array}{l}\text { PFP Process Engineering } \\
\text { Manager }\end{array}$ & $509-373-4869$ & $509-373-2752$ & Mark_W_Gibson@RL.gov \\
\hline $\begin{array}{l}\text { Rich Szempruch } \\
\text { R. W. }\end{array}$ & BWHC & $\begin{array}{l}\text { Shipping cognizant } \\
\text { engineer,-3013 liaison }\end{array}$ & $509-373-1468$ & $509-373-4003$ & $\begin{array}{l}\text { Richard_W_Szempruch } \\
@ \text { RL.gov }\end{array}$ \\
\hline $\begin{array}{l}\text { Paul Roege } \\
\text { P. E. }\end{array}$ & BWHC & PFP Chief Engineer & $509-372-0443$ & $509-373-4274$ & Paul_E_Roege@RL.gov \\
\hline $\begin{array}{l}\text { Jerry Johnston } \\
\text { G. A. }\end{array}$ & FDNW & A-E Project Manager & $509-372-3923$ & $509-372-1164$ & G_A_Jerry_Johnston@RL.gov \\
\hline $\begin{array}{l}\text { Charles O'Neill } \\
\text { C. T. }\end{array}$ & FDNW & Lead Design Engineer & $509-373-7642$ & $509-373-0313$ & Charles_T_O'Neill@RL.gov \\
\hline $\begin{array}{l}\text { Kevin Rowe } \\
\text { K. R. }\end{array}$ & FDNW & $\begin{array}{l}\text { Project Controls \& } \\
\text { Reporting }\end{array}$ & $509-376-8466$ & $509-376-9202$ & Kevin_R_Rowe@RL.gov \\
\hline $\begin{array}{l}\text { John Schultz } \\
\text { J. W. }\end{array}$ & FDNW & Project Quality Assurance & $509-373-5255$ & $509-372-1490$ & John_W_Schultz@RL.gov \\
\hline Shirley Zeller & $\mathrm{BWHC}$ & $\begin{array}{l}\text { PFP Quality Assurance } \\
\text { Manager }\end{array}$ & 509-373-3139 & $509-373-1349$ & Shirley_Zeller@RL.gov \\
\hline $\begin{array}{l}\text { Ron Allen } \\
\text { R. R. }\end{array}$ & BWHC & PFP Safety Manager & $509 \cdot 376-4694$ & $509-373-2993$ & Ronald_R_Allen@RL.gov \\
\hline $\begin{array}{l}\text { Jeff Bramson } \\
\text { J. E. }\end{array}$ & BWHC & $\begin{array}{l}\text { PFP Environmental } \\
\text { Compliance Officer }\end{array}$ & $509-373-1359$ & $509-373-2752$ & Jeffrey_E_Bramson@RL.gov \\
\hline $\begin{array}{l}\text { Bobby Gray } \\
\text { B. J. }\end{array}$ & BWHC & $\begin{array}{c}\text { PFP Maintenance } \\
\text { Manager }\end{array}$ & $509-373-7221$ & $509-373-3190$ & Bobby_J_Gray@RL.gov \\
\hline $\begin{array}{l}\text { Rob Gregory } \\
\text { R. E. }\end{array}$ & BWHC & $\begin{array}{l}\text { PFP Vault Operations } \\
\text { Manager }\end{array}$ & $509-373-9980$ & $509-373-3897$ & $\begin{array}{l}\text { Robert_E_Rob_Gregory } \\
@ \text { RL.gov }\end{array}$ \\
\hline $\begin{array}{l}\text { Mark Hahn } \\
\text { M. R. }\end{array}$ & RL & $\begin{array}{c}\text { Transition Programs } \\
\text { Division }\end{array}$ & $509-373-9872$ & $509-376-0695$ & Mark_R_Hahn@rl.gov \\
\hline $\begin{array}{l}\text { Don Seaborg } \\
\text { W. D. }\end{array}$ & RL & $\begin{array}{c}\text { Transition Programs } \\
\text { Division } \\
\end{array}$ & $509-372-2889$ & $509-376-0695$ & $\begin{array}{l}\text { Wendell_D_Don_Seaborg } \\
\text { @rl.gov }\end{array}$ \\
\hline George Dragseth & RL & Site Engineering & $509-372-0750$ & $509-376-4963$ & George_Dragseth@rl.gov \\
\hline $\begin{array}{l}\text { Dave Sherwood } \\
\text { D. J. }\end{array}$ & RL & $\begin{array}{l}\text { Transition Programs } \\
\text { (Key Contact) }\end{array}$ & $509-376-0038$ & $509-376-0695$ & David_J_Sherwood@rl.gov \\
\hline
\end{tabular}




\begin{tabular}{|c|c|c|c|c|c|}
\hline & & SAYA & NATRTM? & & \\
\hline NAWE & compary & $\begin{array}{l}\text { AREA OF } \\
\text { DXPIPIST }\end{array}$ & FTONE $x$ & TAX & DMAn \\
\hline $\begin{array}{l}\text { Steve Tibrea } \\
\text { S.L. }\end{array}$ & WSRC & $\begin{array}{c}\text { Remote Systems } \\
\text { Engineering Manager }\end{array}$ & $803-725-3210$ & $803-725-7369$ & Steven.Tibrea@SRS.gov \\
\hline $\begin{array}{l}\text { William Lloyd } \\
\text { W.E. }\end{array}$ & WSRC & $\begin{array}{l}\text { FB Line Facility } \\
\text { Manager }\end{array}$ & $803-952-4499$ & - & William.Lloyd@SRS. gov \\
\hline $\begin{array}{l}\text { Jim Wong } \\
\text { J.W. }\end{array}$ & WSRC & $\begin{array}{l}\text { Advanced Remote } \\
\text { Systems Manager }\end{array}$ & $803-725-0701$ & $803-725-7369$ & Jim.Wong@SRS.gov \\
\hline $\begin{array}{l}\text { Mitchell Stokes } \\
\text { M.W. }\end{array}$ & WSRC & Lead Project Engineer & $803-725-1684$ & $803-725-9753$ & Mitchell02.Stokes@SRS.gov \\
\hline $\begin{array}{l}\text { Lane Rogers } \\
\text { M.L. }\end{array}$ & WSRC & Mechanical Lead & $803-725-5700$ & $803-725-9753$ & Lane.Rogers@SRS.gov \\
\hline $\begin{array}{l}\text { Erich Duhn } \\
\text { E.F. }\end{array}$ & WSRC & Business Development & $803-725-8348$ & $803-725-5103$ & Erich.Duhn@SRS.gov \\
\hline $\begin{array}{l}\text { James Powell } \\
\text { J.A. }\end{array}$ & $\overline{\text { WSRC }}$ & QA Manager & $803-725-3081$ & $803-725-1241$ & James02.Powell@SRS.gov \\
\hline $\begin{array}{l}\text { James Gray } \\
\text { J.P. }\end{array}$ & WSRC & QA Engineer & $803-725-0781$ & $803-725-1744$ & James.Gray@SRS.gov \\
\hline $\begin{array}{l}\text { Chip McClard } \\
\text { J.W. }\end{array}$ & WSRC & $\begin{array}{l}\text { Shipping-3013 } \\
\text { Container Engineer }\end{array}$ & $803-952-4612$ & $803-952-4429$ & James.Mcclard@SRS.gov \\
\hline $\begin{array}{l}\text { Davie Shull } \\
\text { D.J. }\end{array}$ & WSRC & Electrical Lead & $803-725-3083$ & $803-725-9753$ & Davis.Shull@SRS.gov \\
\hline $\begin{array}{l}\text { Terry } \\
\text { Montgomery } \\
\text { T.L. }\end{array}$ & DOE-SR & $\begin{array}{l}\text { Technical Program } \\
\text { Manager }\end{array}$ & $803-725-7789$ & $803-725-5968$ & Terry.Montgomery@SRS.gov \\
\hline
\end{tabular}




\section{APPENDIX E}

\section{BCR PATH FORWARD CROSSWALK}




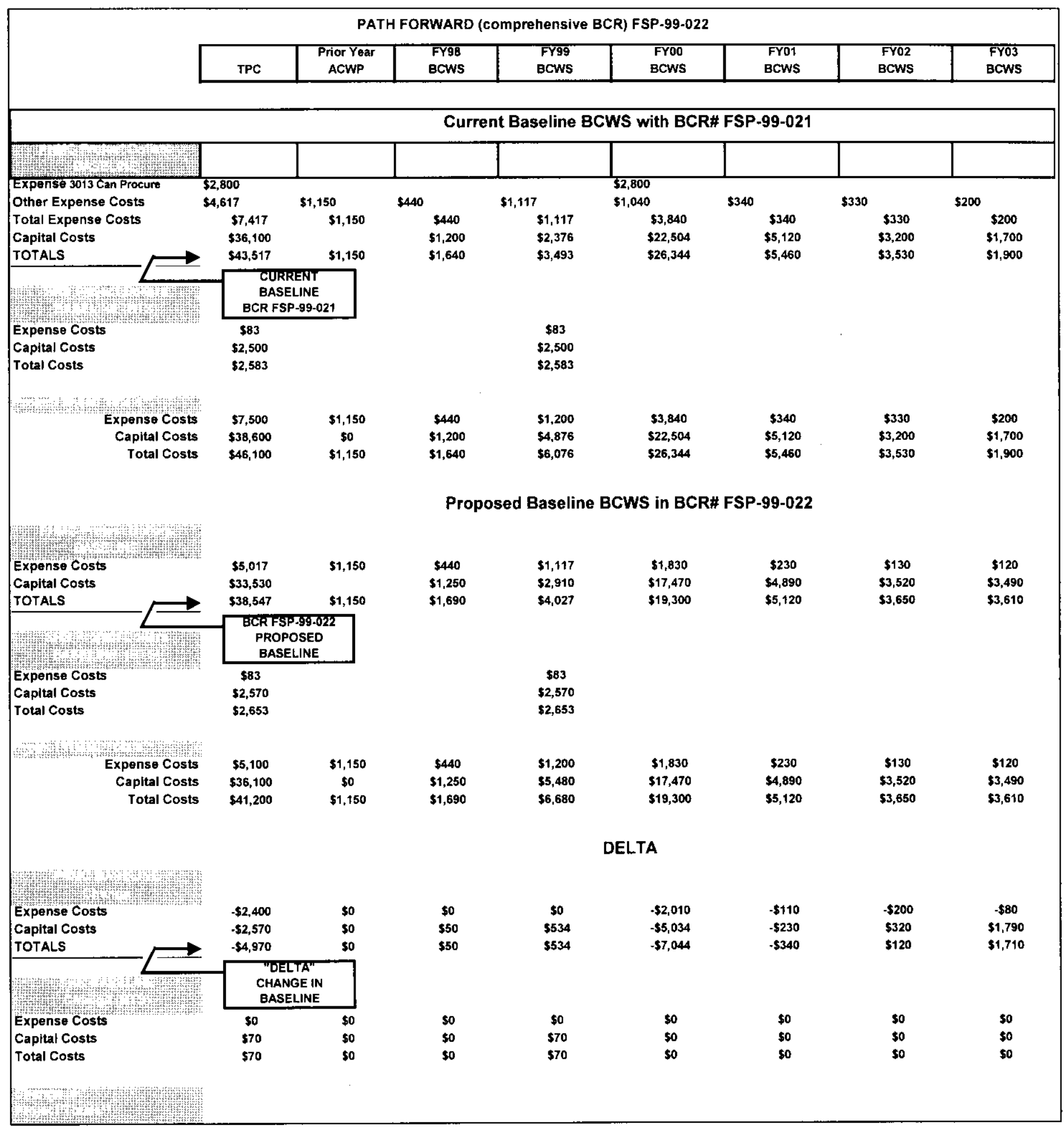




\section{APPENDIX F}

\section{ENVIRONMENTAL REQUIREMENTS CHECKLIST}




\section{PROJECT W-460 \\ Plutonium Stabilization and Handling}

Scope of Work:

The U. S. Department of Energy has revised its Technical Standard for the long-term storage of certain fissile materials (DOE-STD-3013-96, Criteria for Preparing and Packaging Plutonium Metals and Oxides for Long-Term Storage). The mission of the Plutonium Finishing Plant (PFP) is to remove all plutonium-bearing fissile materials from the processing facility, stabilize the facility in preparation for final decommissioning, and provide safe secure storage until the materials can be shipped to a designated long-term storage facility. Fissile materials stabilized and packaged at the PFP for long-term storage must comply with the criteria in this Standard. Materials currently awaiting stabilization and packaging include various forms; very little of this material has been stabilized to meet the high-temperature criteria for long term storage.

Project W-460 scope of work includes modification of the PFP vault support area and ventilation system to accommodate new stabilization and packaging equipment (SPE), installation and testing of the SPE, modification of storage fixtures and ventilation systems to accommodate standardized packages ("3013 cans"), and procurement of an initial quantity of 3013 cans.

Due to displacement of vault operations staff from 2736-ZB to accommodate the SPE, the project will also install a mobile operations support building at the PFP, which will include staff space, rest rooms and change rooms. Installation of the mobile structure will require tie-in to the 2736-ZB sanitary effluent lift station.

\section{EXPLANATION OF ENVIRONMENTAL REQUIREMENTS CHECKLIST AND NARRATIVE}

The following table identifies environmental permits, approvals, and/or requirements applicable to the Project. Any "Yes" or "To Be Determined" answer in the applicability column will be further described in the narrative that follows the table. Some "No" answers may require special explanation and will have narrative associated with them. If this is the case, the words "See Narrative" will be stated in the applicability column. A contact is identified at the end of each evaluation to answer questions and/or provide additional information regarding the specific regulation in question. If the contact cannot be reached, Project Services may be contacted to obtain answers to questions or to coordinate meetings with appropriate personnel within Environmental Services. 


\title{
ABBREVIATIONS and ACRONYMS
}

\author{
ALARA As Low As Reasonably Achievable \\ AOP Air Operating Permit \\ ARAs Applicable or Relevant and Appropriate Requirements \\ BAC Best Available Control Technology \\ BARCT Best Available Radionuclide Control Technology \\ BCCAA Benton County Clean Air Authority \\ BFDHD Benton-Franklin District Health Department \\ CAA Clean Air Act \\ CDR Conceptual Design Report \\ CERCLA Comprehensive Environmental Response, Compensation, and Liability Act \\ CFC Chlorofluorocarbons \\ CFR Code of Federal Regulations \\ CERR Cultural and Ecological Resource Review \\ CX Categorical Exclusion \\ DOE-HQ U.S. Department of Energy-Headquarters \\ DOH State of Washington Department of Health \\ DNS Determination of Non-Significance (by Ecology) \\ DST double-shell tank \\ EA Environmental Assessment \\ Ecology State of Washington Department of Ecology \\ EIS Environmental Impact Statement \\ EIS/ODISEffluent Information System/Onsite Discharge Information System \\ EPA U.S. Environmental Protection Agency \\ FR Federal Register \\ FONSI Finding of No Significant Impact \\ gpd gallons per day \\ HCRL Hanford Cultural Resource Laboratory \\ HLAN Hanford Local Area Network \\ HPA Hydraulic Projects Approval \\ IB Information Bulletin \\ IEU insignificant emission units \\ LDUA light duty utility arm \\ MEI Maximum Exposed Individual \\ mrem millirem \\ MTF Memorandum-To-File \\ MWC Municipal Waste Combustor \\ NEPA National Environmental Policy Act \\ NESHAPs National Emission Standards for Hazardous Air Pollutants \\ NOC Notice of Construction \\ NOI Notice of Intent \\ NPDES National Pollutant Discharge Elimination System \\ NSR New Source Review \\ PAA Price-Anderson Amendments review
}


PFP Plutonium Finishing Plant

POC Point of Contact

PL Public Law

PNNL Pacific Northwest National Laboratory

PSD Prevention of Significant Deterioration

RCRA Resource Conservation and Recovery Act

RL U.S. Department of Energy, Richland Operations Office

SEPA State Environmental Policy Act

SPE Stabilization and Packaging equipment

SST single-shell tank

SWDP State Waste Discharge Permit

TAPs Toxic Air Pollutants

T-BACT Best Available Control Technology for Toxics

TEDE Total Effective Dose Equivalent

T-RACT Reasonably Available Control Technology for Toxics

TPA Tri-Party Agreement or Hanford Federal Facility Agreement and Consent Order

TSD Treatment, Storage, and/or Disposal

UIC Underground Injection Control

USACE U.S. Army Corps of Engineers

\subsection{USFWS U.S. Fish and Wildlife Service}

UST Underground Storage Tanks

WAC Washington Administrative Code

WMH Waste Management Federal Services of Hanford, Inc. 
SUMMARY CHECKLIST OF POTENTIAL PERMITS/APPROVALS/REQUIREMENTS

\begin{tabular}{|c|c|c|c|c|c|}
\hline $\begin{array}{l}\text { ENVIRON } \\
\text { MENT- } \\
\text { MEDIA }\end{array}$ & $\begin{array}{l}\text { PERMIT, } \\
\text { APPROVAL, } \\
\text { or } \\
\text { REQUIREMENT }\end{array}$ & REGULATION(S) & $\begin{array}{c}\text { REGULATO } \\
\text { RY } \\
\text { AGENCY }\end{array}$ & RESTRICTION & $\begin{array}{c}\text { APP. } \\
(\mathbf{Y} \text { or } N)\end{array}$ \\
\hline \multirow[t]{2}{*}{ NEPA } & $\begin{array}{l}\text { NEPA } \\
\text { Documentation }\end{array}$ & $\begin{array}{l}\text { 40 CFR 1500-1508 } \\
10 \text { CFR } 1021 \\
\text { DOE Order } 451.1 \mathrm{~A}\end{array}$ & DOE & $\begin{array}{l}\text { Title II Design } \\
\text { (Projects); } \\
\text { Procurement } \\
\end{array}$ & $\mathrm{Y}$ \\
\hline & $\begin{array}{l}\text { Price-Anderson } \\
\text { Review }\end{array}$ & 10 CFR 835 & $\begin{array}{l}\text { DOE \& } \\
\text { PHMC legal }\end{array}$ & $\begin{array}{l}\text { Operational } \\
\text { Readiness } \\
\end{array}$ & $Y$ \\
\hline SEPA & SEPA & WAC $197-11$ & State Agency & License, Permit & $\mathrm{N}$ \\
\hline $\begin{array}{l}\text { Environme } \\
\text { ntal } \\
\text { Critique } \\
\end{array}$ & NEPA 216 Process & 0 CFR 1021.216 & $\begin{array}{l}\text { PHMC } \\
\text { Procurement } \\
\text { \& DOE-RL } \\
\end{array}$ & $\begin{array}{l}\text { Contract } \\
\text { placement }\end{array}$ & $\mathrm{Y}$ \\
\hline CERCLA & ARARs & 40 CFR 300 to 400 & EPA & Construction & $\mathrm{N}$ \\
\hline \multirow[t]{4}{*}{$\begin{array}{l}\text { Nonrad. Air } \\
\text { Emissions }\end{array}$} & $\begin{array}{l}\text { New Source } \\
\text { Review/NOC; Source } \\
\text { Registration } \square[]\end{array}$ & $\begin{array}{l}\text { WAC 173-400-040; } \\
\text { WAC 173-400-110; }\end{array}$ & Ecology & Construction & $y$ \\
\hline & PSD & WAC 173-400-141 & Ecology; & Construction & $\mathrm{N}$ \\
\hline & TAPs & $\begin{array}{l}\text { WAC 173-460-030; } \\
-040\end{array}$ & Ecology & Construction & $\mathrm{N}$ \\
\hline & $\begin{array}{l}\text { Dangerous and/or } \\
\text { Hazardous waste } \\
\text { air emissions }\end{array}$ & $\begin{array}{l}\text { WAC } 173-303 \\
-120(4)(\mathrm{e}),-400(3), \\
-690, \text { and }-691, \\
\text { 40CFR 264/265 } \\
\text { Subpart CC } \\
\end{array}$ & $\begin{array}{l}\text { Ecology } \\
\text { And } \\
\text { EPA }\end{array}$ & Operations & $\mathrm{N}$ \\
\hline \multirow{2}{*}{$\begin{array}{l}\text { Radioactive } \\
\text { Air } \\
\text { Emissions }\end{array}$} & NESHAPS & $\begin{array}{l}40 \text { CFR 61, Subpart } \\
\mathrm{H}\end{array}$ & EPA & Construction & $\mathrm{Y}$ \\
\hline & $\begin{array}{l}\text { Radiation Protection - } \\
\text { Air Emissions } \\
\end{array}$ & WAC $246-247-060$ & $\mathrm{DOH}$ & $\begin{array}{l}\text { Construction; } \\
\text { Operation } \\
\end{array}$ & $\mathrm{Y}$ \\
\hline \multirow[t]{2}{*}{$\begin{array}{l}\text { All Air } \\
\text { Emissions }\end{array}$} & Air Operating Permit & WAC $173-401$ & $\begin{array}{l}\text { Ecology; } \\
\mathrm{DOH} ; \mathrm{EPA}\end{array}$ & $\begin{array}{l}\text { Input to update: } \\
\text { Operation }\end{array}$ & $\mathrm{Y}$ \\
\hline & $\begin{array}{l}\text { T-BACT; BARCT, } \\
\text { ALARCT }\end{array}$ & $\begin{array}{l}\text { WAC } 173-460-30 \\
\text { WAC 246-247-40, } \\
\text { WAC 246-247-130 }\end{array}$ & $\begin{array}{l}\text { Ecology } \\
\& / \text { or } \\
\text { DOH }\end{array}$ & $\begin{array}{l}\text { Construction, } \\
\text { Operation }\end{array}$ & $\overline{\mathrm{TBA}}$ \\
\hline
\end{tabular}




\begin{tabular}{|c|c|c|c|c|c|}
\hline $\begin{array}{l}\text { ENVIRON } \\
\text { MENT- } \\
\text { MEDIA }\end{array}$ & $\begin{array}{l}\text { PERMIT, } \\
\text { APPROVAL, } \\
\text { or } \\
\text { REQUIREMENT }\end{array}$ & REGULATION(S) & $\begin{array}{c}\text { REGULATO } \\
\text { RY } \\
\text { AGENCY }\end{array}$ & RESTRICTION & $\begin{array}{c}\text { APP. } \\
(\mathbf{Y} \text { or } N)\end{array}$ \\
\hline $\begin{array}{l}\text { Special } \\
\text { Substances }\end{array}$ & $\begin{array}{l}\text { Air emissions, Liquid } \\
\text { discharge, waste oils }\end{array}$ & $\begin{array}{l}\text { PCB contaminated: } \\
40 \text { CFR } 746 \text { et seq, } \\
\text { Toxic Substances: } \\
\text { 40 CFR } 720,-740, \\
\text { CFR } 247 \text { Pesticides: } \\
\text { WAC-228 to -232 }\end{array}$ & $\begin{array}{l}\text { Ecology, } \\
\text { BCCAA, } \\
\text { Washington } \\
\text { Dept of } \\
\text { Agriculture }\end{array}$ & $\begin{array}{l}\text { Special training, } \\
\text { Special controls, } \\
\text { Notifications } \\
\text { before working } \\
\text { with substance }\end{array}$ & TBA \\
\hline Asbestos & NOI & $\begin{array}{l}\text { BCCAA Reg } 1 \text {, } \\
\text { Article } 8 \text {, } \\
40 \text { CFR } 61 \text {, Subpart } \\
\text { M }\end{array}$ & $\overline{\mathrm{BCCAA}}$ & $\begin{array}{l}\text { Special training, } \\
\text { Special controls, } \\
\text { Notifications } \\
\text { before working } \\
\text { with Asbestos }\end{array}$ & $\mathrm{N}$ \\
\hline $\begin{array}{l}\text { Outdoor or } \\
\text { Unconfined } \\
\text { Burning } \\
\end{array}$ & Burn Permit & $\begin{array}{l}\text { WAC 173-425; } \\
\text { BCCAA Reg. } 1 \text {, } \\
\text { Article } 5\end{array}$ & $\begin{array}{l}\text { Hanford Fire } \\
\text { Department } \\
\text { BCCAA }\end{array}$ & Open Burning & $\mathrm{N}$ \\
\hline $\begin{array}{l}\text { Ozone } \\
\text { Depleting } \\
\text { Substances/ } \\
\text { CFCs } \\
\end{array}$ & $\begin{array}{l}\text { Release Prevention; } \\
\text { Recovery/Recycle; } \\
\text { Certification } \\
\text { Labeling } \\
\end{array}$ & 40 CFR 82 & $\overline{\text { Ecology }}$ & $\begin{array}{l}\text { Reporting; } \\
\text { Training; } \\
\text { Operation }\end{array}$ & $\mathrm{N}$ \\
\hline \multirow[t]{3}{*}{$\begin{array}{l}\text { Soil } \\
\text { Column } \\
\text { Waste } \\
\text { Water } \\
\text { Disposal }\end{array}$} & $\begin{array}{l}\text { SWDP Water Quality } \\
\text { Stds }\end{array}$ & $\begin{array}{l}\text { WAC } 173-200, \\
\text { WAC } 173-216 / 218, \\
\text { DOE } 5400.1, \\
5400.5, \\
10 \text { CFR } 40 \\
\end{array}$ & Ecology, DOH & $\begin{array}{l}\text { Operation } \\
\text { (Monitoring Plan) }\end{array}$ & $\overline{\mathrm{N}}$ \\
\hline & $\begin{array}{l}\text { Approval of Engr. } \\
\text { Report, Plans \& } \\
\text { Specs., and O\&M } \\
\text { Manual }\end{array}$ & WAC $173-240$ & Ecology & Construction & $\mathrm{N}$ \\
\hline & $\begin{array}{l}\text { UIC Permit/ } \\
\text { Registration }\end{array}$ & WAC $173-218$ & Ecology & Operation & $\mathrm{N}$ \\
\hline \multirow[t]{4}{*}{$\begin{array}{l}\text { Domestic } \\
\text { Waste } \\
\text { Water } \\
\text { Disposal }\end{array}$} & $\begin{array}{l}\text { Septic Systems } \\
<14,500 \text { gpd } \\
\text { Capacity } \\
\text { Design Approval }\end{array}$ & $\overline{\text { WAC 246-272 }}$ & $\mathrm{DOH}$ & Construction & $\overline{\bar{Y}}$ \\
\hline & Pretreatment Permit & $\begin{array}{l}40 \text { CFR } 403 ; \\
\text { City Ordinance }\end{array}$ & $\begin{array}{l}\text { City of } \\
\text { Richland }\end{array}$ & $\begin{array}{l}\text { Discharge to City } \\
\text { Sewage Facility }\end{array}$ & $\mathrm{N}$ \\
\hline & $\begin{array}{l}\text { Operator } \\
\text { Certification }\end{array}$ & WAC $173-230$ & Ecology & Operation & $\overline{\mathrm{N}}$ \\
\hline & Discharge Standards & WAC 173-221 & Ecology & Discharge & $\mathrm{N}$ \\
\hline
\end{tabular}




\begin{tabular}{|c|c|c|c|c|c|}
\hline \multirow{12}{*}{$\begin{array}{l}\text { Surface } \\
\text { Waste } \\
\text { Water } \\
\text { Disposal }\end{array}$} & NPDES Permit & $\begin{array}{l}40 \text { CFR } 122 \\
57 \text {. }\end{array}$ & $\begin{array}{l}\text { EPA } \\
\text { DDA }\end{array}$ & Operation & $\overline{\mathrm{N}}$ \\
\hline & $\begin{array}{l}\text { Storm Water } \\
\text { Discharge Under } \\
\text { General Permit }\end{array}$ & 57 FR No. 175 & EPA & $\begin{array}{l}\text { River } \\
\text { Construction }\end{array}$ & $\mathrm{N}$ \\
\hline & $\begin{array}{l}\text { U.S. Dept of Army } \\
\text { Permit }\end{array}$ & 33 CFR 325 & USACE & $\begin{array}{l}\text { River } \\
\text { Construction }\end{array}$ & $\mathrm{N}$ \\
\hline & Section 10 Permit & $\begin{array}{l}33 \text { CFR 320; } \\
33 \text { CFR } 322\end{array}$ & USACE & $\begin{array}{l}\text { River } \\
\text { Construction }\end{array}$ & $\overline{\mathrm{N}}$ \\
\hline & Nationwide Permits & 33 CFR 330 & USACE & $\begin{array}{l}\text { River } \\
\text { Construction }\end{array}$ & $\mathrm{N}$ \\
\hline & $\begin{array}{l}\text { Hydraulic Projects } \\
\text { Permit }\end{array}$ & WAC $220-110$ & $\begin{array}{l}\text { WA State } \\
\text { Dept. of } \\
\text { Fisheries }\end{array}$ & $\begin{array}{l}\text { River } \\
\text { Construction }\end{array}$ & $\mathrm{N}$ \\
\hline & $\begin{array}{l}\text { Shoreline } \\
\text { Development Permit }\end{array}$ & WAC $173-14$ to -20 & $\begin{array}{l}\text { Benton } \\
\text { County }\end{array}$ & $\begin{array}{l}\text { River/Island } \\
\text { Construction }\end{array}$ & $\mathrm{N}$ \\
\hline & Aquatic Lands Lease & WAC $332-30$ & DNR & Construction & $\mathrm{N}$ \\
\hline & $\begin{array}{l}\text { Hanford Reach Study } \\
\text { Act Notification }\end{array}$ & PL 100-605 & $\begin{array}{l}\text { U.S. Park } \\
\text { Service }\end{array}$ & $\begin{array}{l}\text { Construction } \\
\text { within } 1 / 4 \mathrm{mi} \text {. of } \\
\text { River }\end{array}$ & $\mathrm{N}$ \\
\hline & $\begin{array}{l}\text { Water Quality } \\
\text { Modification Permit }\end{array}$ & WAC 173-201 & Ecology & $\begin{array}{l}\text { River } \\
\text { Construction }\end{array}$ & $\mathrm{N}$ \\
\hline & $\begin{array}{l}\text { Certification of } \\
\text { NPDES Permit }\end{array}$ & 40 CFR 121 & Ecology & Operation & $\mathrm{N}$ \\
\hline & Categorical Standards & 40 CFR 405 to 471 & EPA & Operation & $\mathrm{N}$ \\
\hline \multirow[t]{3}{*}{$\begin{array}{l}\text { Drinking } \\
\text { Water } \\
\text { Supply }\end{array}$} & $\begin{array}{l}\text { Approval of Engr. } \\
\text { Report, Plans \& } \\
\text { Specs. } \\
\end{array}$ & WAC $246-290$ & $\mathrm{DOH}$ & Construction & $\mathrm{N}$ \\
\hline & System ID. Number & WAC $246-290$ & $\mathrm{DOH}$ & Operation & $\mathrm{N}$ \\
\hline & $\begin{array}{l}\text { Operator } \\
\text { Certification }\end{array}$ & WAC 246-292 & $\mathrm{DOH}$ & Operation & $\mathrm{N}$ \\
\hline Solid Waste & $\begin{array}{l}\text { Solid Waste Handling } \\
\text { Facility Permit }\end{array}$ & WAC $173-304$ & BFDHD & Construction & $\mathrm{N}$ \\
\hline
\end{tabular}




\begin{tabular}{|c|c|c|c|c|c|}
\hline \multirow[t]{2}{*}{$\begin{array}{l}\text { Dangerous } \\
\text { Waste }\end{array}$} & $\begin{array}{l}\text { Dangerous Waste } \\
\text { Permit (RCRA } \\
\text { Part A and B) }\end{array}$ & $\begin{array}{l}\text { WAC 173-303-800 } \\
\text { thru-860; } \\
40 \text { CFR 264; } \\
40 \text { CFR 265; } \\
40 \text { CFR 270 }\end{array}$ & Ecology & $\begin{array}{l}\text { Construction of } \\
\text { New Facilities or } \\
\text { Expansion of } \\
\text { Existing Facilities }\end{array}$ & $\mathrm{N}$ \\
\hline & $\begin{array}{l}\text { Construction or } \\
\text { expansion of surface } \\
\text { impoundments, waste } \\
\text { piles, or landfill } \\
\text { units }\end{array}$ & WAC 173-303-335 & Ecology & $\begin{array}{l}\text { Construction } \\
\text { quality assurance } \\
\text { plans, program, } \\
\text { and certification }\end{array}$ & $\mathrm{N}$ \\
\hline UST & Tank Permit & WAC $173-360$ & Ecology & Operation & $\mathrm{N}$ \\
\hline \multirow[t]{6}{*}{ All Media } & $\begin{array}{l}\text { Floodplain, Wetland } \\
\text { Assessment }\end{array}$ & 10 CFR 1022 & DOE & $\begin{array}{l}\text { Any Surface } \\
\text { Disturbance } \\
\end{array}$ & $\mathrm{N}$ \\
\hline & $\begin{array}{l}\text { Cultural Resource } \\
\text { Review }\end{array}$ & 36 CFR 800 & DOE & $\begin{array}{l}\text { Any Surface } \\
\text { Disturbance; } \\
\text { Modification of } \\
\text { Bldgs. Eligible } \\
\text { for Listing on } \\
\text { Historical } \\
\text { Register } \\
\end{array}$ & $\mathrm{Y}$ \\
\hline & Excavation Permit & 36 CFR 800 & DOE & Any Excavation & Y \\
\hline & $\begin{array}{l}\text { Ecological } \\
\text { Compliance Review }\end{array}$ & $\begin{array}{l}10 \text { CFR } 1021 ; \\
50 \text { CFR } 402.6 \\
\text { DOE Order } 5484.1\end{array}$ & USFWS & $\begin{array}{l}\text { Construction; } \\
\text { Habitat } \\
\text { Modification } \\
\end{array}$ & $\mathrm{Y}$ \\
\hline & $\begin{array}{l}\text { Preoperational } \\
\text { Monitoring of } \\
\text { Facilities, Sites, and } \\
\text { Operations }\end{array}$ & DOE Order 5400.1 & DOE & Operation & $\mathrm{N}$ \\
\hline & $\begin{array}{l}\text { Radiation Protection } \\
\text { Standards }\end{array}$ & DOE Order 5400.5 & DOE & Construction & $\mathrm{Y}$ \\
\hline
\end{tabular}

NEPA

\section{NEPA Documentation - Title 10, CFR 1021}

A NEPA review is required for all proposed actions at the Hanford Site.

Documentation of the completed NEPA review process could include an EIS, an EA or a CX. The EIS is required for proposed major federal actions that could 
significantly affect the quality of the human environment. In cases where the need for an EIS is uncertain, an EA is prepared. A CX is issued by RL if the proposed action clearly would have no significant impact on the quality of the human environment. However, most actions determined to be categorically excludable must be documented. A NEPA Documentation Request Checklist is available on Site Forms on the Hanford Local Area Network, to be completed and forwarded to PHMC NEPA Services to initiate the necessary review process. NEPA Documentation must be completed before starting Title II Design. Note that all cultural resource surveys and ecological survey/reviews must be completed before any NEPA documentation is submitted to RL.

\section{EVALUATION:}

The Plutonium Finishing Plant Environmental Impact Statement issued in May of 1996 and the Record of Decision approved on June 25, 1996, include discussion of the stabilization of plutonium-bearing materials remaining at the PFP. Materials containing greater than thirty percent Pu will be stabilized, packaged and stored at the PFP until shipment offsite for longterm storage. The modification of 2736-ZB Building for installation of stabilization and packaging equipment, the installation of support equipment, the installation of a mobile operations support building and tie-in to the sanitary effluent system will require a NEPA review. For more information contact Mr. M. T. Jansky on 376-3854 or Ms. B. Nelson-Maki on $372-3058$.

\section{$\underline{\text { SEPA }}$}

\section{SEPA Documentation - WAC 197-11}

SEPA is the State or local equivalent of NEPA that requires evaluation of environmental impacts associated with a project before it can be approved. A SEPA checklist is completed if required by Ecology (typically only if a state permit is needed). An EA under NEPA may substitute for the SEPA checklist. Ecology will determine if a State EIS is required or will issue a determination of nonsignificance.

\section{EVALUATION:}

The current process knowledge does not indicate the presence of TAP's or the need to submit a permit to the State of Washington Department of Ecology. Completion of a SEPA checklist is not anticipated to be required. For more information contact contact Mr. M. T. Jansky on 376-3854. 


\section{CERCLA}

\section{CERCLA ARARs - 40 CFR 300 to 400}

No federal, State, or local permits are required for onsite response actions covered by CERCLA, Sections 104, 106, 120,121, 121, or 122. This exception is allowed because onsite response actions must comply with the substantive parts of ARARs. On the Hanford Site, an activity is recognized as a CERCLA activity if the unit is identified as a CERCLA unit in the Tri-Party Agreement, or the activity is documented and performed in accordance with the CERCLA process. CERCLA remedial actions must comply with the substantive requirements of ARARs during the remedial action and upon completion of the remedial action. Additionally, removal actions, commonly called interim actions or expedited response actions, must comply with ARARs depending upon the exigencies of the circumstances and the scope of the removal action. The substantive portions of ARARs are generally required unless the removal is an emergency situation that does not allow for a planning phase to identify ARARs.

\section{EVALUATION:}

This section is not applicable. Project W-460 will not affect any CERCLA sites. For more information, contact Mr. J. E. Bramson on 373-1359.

\section{NONRADIOACTIVE AIR EMISSIONS}

\section{General Regulations for Air Pollution Sources - WAC 173-400-040}

\section{NSR Applicability - WAC 173-400-110}

Before a new or modified source of regulated air emissions is constructed, installed, or established, Ecology must review plans, specifications, associated information, and NOC's related to the new or modified source.

An NOC is a written application to permit construction of a new source or modification of an existing source. The application describes the proposed design, assesses potential impacts to the public and environment, and provides an assessment of BACT. An NOC for nonradioactive air emissions may be required because of requirements of two regulations: sources subject to WAC 173-400 (including 40 CFR 60 and 61) and WAC 173-460 may need an NOC prepared for preconstruction approval according to each regulation. In some cases a single, combined NOC may be submitted for approval by the appropriate State or local agency. The descriptions under the following subtitles identify these specific regulations and NOC requirements. 


\section{PSD - WAC 173-400-141}

Any increased emission of criteria pollutants from a new or modified source may trigger a significant modification as defined by 40 CFR 52.21. Potential annual amounts of expected increases must be considered. Preconstruction approval may be required by Ecology. The criteria pollutants include:

- Carbon monoxide

- Nitrogen oxides

- Sulfur dioxides

- Particulate matter and PM-10

- Ozone (volatile organic compounds)

- Lead (elemental)

- Fluorides

- Sulfuric acid mist

- Total reduced sulfur compounds (including $\mathrm{H}_{2} \mathrm{~S}$ )

- CFCs 11, 12, 113, 114, 115

- Halons 1211, 1301, 2402

- MWC acid gases, MWC metal, and MWC organics.

If an NOC is required, the potential annual emissions of the criteria pollutants must be reported in that NOC. (See NOC Section.)

\section{EVALUATION:}

No increase in PSD criteria pollutants is expected with this installation and operation of the process. The NOC written to cover Project W-460 will address these concerns in more detail. For more information contact Mr. J. E. Bramson on 373-1359 or Mr. J. S. Hill on $372-1617$.

\section{Controls for New Sources of TAPs - WAC 173-460-030; -040}

Some key questions and requirements of an analysis regarding WAC 173-460 applicability include:

- Will the source emit TAPs other than nonprocess fugitive emissions in a significant quantity?

- Does the source fall into a source category listed in WAC 173-460 or WAC $173-400$ ?

- Is the source exempt? 
- Is this a "new source" of TAPs?

- T-BACT for TAPs is required for applicable sources having increased or new TAPs emissions.

- T-RACT for TAPs is required for projects that will cause the rate of TAPs emissions to decrease or stay the same.

\section{EVALUATION:}

The thermal stabilization process that will be used in Project W-460 is not expected to create any new TAP emission sources. This will be evaluated further. For more information contact

Mr. J. E. Bramson on 373-1359 or Mr. J. S. Hill on 372-1617.

\section{$\underline{\text { RADIOACTIVE AIR EMISSIONS }}$}

\section{NESHAPs - 40 CFR 61, Subpart H}

Any new stationary source of radionuclide emissions is subject to a preconstruction review and approval by the EPA, Region 10. Also, any new physical or operational activity that will provide any increase in potential emissions of radionuclides is defined as a modification that also may require approval.

\section{EVALUATION:}

The operation of the SPE equipment will require a new process stack to be constructed on the 2736-ZB building. This stack is anticipated to be a NESHAP-compliant major stack, with appropriate sampling and monitoring capability. The addition of the stack and upgrading of the classification will require that a NESHAP assessment be performed and the approval of the State of Washington Department of Health. For more information, please contact Mr. J. E. Bramson on 373-1359 or Mr. J. S. Hill on 372-1617.

\section{Radiation Protection - Air Emissions - WAC 246-247-060}

\section{Registration of Source - WAC 246-247-060}

The EIS/ODIS is an annual report provided to DOE in accordance with DOE Order 5400.1. If a source is listed in the EIS/ODIS, it must be registered with the DOH. Furthermore, the DOH will make a case-by-case determination regarding the need to register any new or modified source of radioactive air emissions requiring an NOC. 
One basis for determining if a source must be listed in the EIS/ODIS, thus requiring registration, is the PNMC criterion for record sampling, listed in HNF-PRO-450, .

\section{EVALUATION:}

For more information contact Mr. T. P. Frazier at 373-4306.

\section{NOC - WAC 246-247-060}

Any new activity, process, or equipment that will involve potential emissions of radionuclides to the air is subject to a preconstruction review and approval by the $\mathrm{DOH}$. Also, if the activity involves a physical or operational change at an existing source of radionuclide air emissions, and the change will result in ANY increase in the rate of emissions of radionuclides to the ambient air from the existing source, a modification will occur according to the WAC 246-247, and review and approval by the $\mathrm{DOH}$ is required. To determine whether a change constitutes such a modification, emissions that will result after the changes are compared to a baseline that is normally the annual rate of emissions observed from the facility, structure, or operation during the previous two years of operations. Other options for definition of the baseline exist and may be negotiated with the DOH.

The increase may be related to such factors as increased flow rate or concentration of effluent, upstream heating or mixing of source material, or increased exposure to outside air. When determining whether increased emissions would occur, additional abatement by any planned emissions control equipment may not be factored in.

An NOC application must be filed to obtain prior DOH approval of the new or modified activity. The NOC must include a description of the new construction or modification activities with details concerning any affect the planned construction activity, or the new or changed operations would have regarding containment or release of radionuclide air emissions. The NOC must also include estimates of actual and potential emissions and an assessment of BARCT as defined in the WAC 246-247. For activities having lesser potential for radioactive emissions, it is possible to gain $\mathrm{DOH}$ approval in a streamlined manner by providing a brief description of the proposed activity (written and oral), including a summary of the information mentioned above, to the DOH during a regularly scheduled monthly meeting. DOH approvals provided at the monthly meetings are documented in meeting minutes signed by representatives of DOH and RL, and represent an approved NOC.

\section{EVALUATION:}

Project W-460 will require that a Notice of Construction be prepared and submitted to the 
State of Washington Department of Health and the U.S. EPA for approval. the activity greatly increase the potential to emit. This should be submitted three months prior to the expected start date of construction. The notice of construction covers the construction and operation of the equipment. The regulators, by law, have 60 days to approve, disapprove or require further information be provided in the notice of construction. For further information contact Ms. P. K. Aardal at 373-6434.

\section{$\underline{\text { ALL AIR EMISSIONS }}$}

\section{Air Operating Permit - WAC 173-401}

WAC 173-401 establishes the elements of a comprehensive Washington State AOP program consistent with the requirements of Title V of the Federal Clean Air Act. A sitewide permit is required for the Hanford facilities. This permit will address both radioactive and nonradioactive airborne emissions from all emission units that are above the listed threshold limits defined as significant under the Act. The airborne emissions include, but are not limited to, criteria pollutants and hazardous air pollutants (including radionuclides). In this regulation, Ecology also has established thresholds for regulated pollutants below which emissions would be considered insignificant for the purposes of the operating permit program. Ecology has proposed new sections to Chapter 173-401 to define IEUs and activities. Categorically exempt units/activities may be omitted from the permit. Other IEU items/activities must be listed on the permit, but are exempt from the administrative requirements of the permit.

The permit will establish emission limits and conditions of operation restrictions for major sources on the Hanford Site. If a new NOC is required and an emission unit becomes operational after the permit is issued by the state, a permit revision will be required within twelve months after commencing operation. This application for modification shall be prepared in accordance with WAC 173-401-725. The NOC and permit modification can be sought concurrently. Any NOC application and associated documentation should be retained for future use in the Air Emissions Inventory that will be supporting the preparation of the Title V AOP application.

\section{EVALUATION:}

The PFP Environmental Engineering group will need to request that this stack be changed from a minor stack to a NESHAP compliant major stack. Additional requirements will need to be evaluated. For additional information contact Ms. P. K. Aardal at 373-6434 or Mr. P. J. Sullivan at 373-1788. 


\section{ASBESTOS}

\section{Asbestos - BCCAA General Regulation 1, Article 8; 40 CFR 61, Subpart M}

Proposed reconstruction, repair, or demolition involving asbestos must be reviewed by WHC Hanford Restoration and Operations group for possible preproject notification to the BCCAA.

\section{EVALUATION:}

The 2736-ZB facility is not identified as containing any asbestos material. Should asbestos be encountered during construction activities the work will be stopped. Work will be resumed once proper asbestos control work plans are put in place.

\section{OUTDOOR OR UNCONFINED BURNING}

\section{Fire - WAC 173-425; BCCAA, Regulation 1, Article 5}

Any use of unconfined burning requires a permit from the local BCCAA obtained through the Hanford Fire Department. Special burn permits are required for demolition or fire training.

\section{Evaluation:}

Project W-460 will not require any unconfined burning. 


\section{OZONE DEPLETING SUBSTANCES/CFCS}

\section{Ozone Depleting Substances/CFCs - 40 CFR 82}

Any person who produces, transforms, destroys, imports or exports a controlled (ozone depleting) substance must perform the required reporting, training, and operations specified.

\section{EVALUATION:}

No CFC compounds have been identified to be used in Project W-460 or the operation of the stabilization process.

\section{SOIL COLUMN WASTE WATER DISPOSAL}

\section{SWDP - WAC 173-216}

An SWDP is required before waste materials from industrial, commercial, and municipal operations are discharged into ground and surface waters of the state and into municipal sewerage systems. An SWDP is not required for discharges of pollutants into navigable waters covered by an NPDES permit program.

\section{EVALUATION:}

Project W-460 will not be discharging liquid effluents to the Columbia River. Rain water will be allowed to run off of the buildings directly to the ground. Septic systems will be managed in accordance with regulations and not directly discharged to the ground or waters. Any liquid effluents from equipment will be containerized and upon completion of analyses will be disposed of in accordance with federal, state and local regulations. For additional information contact

Ms. P. K. Aardal at 373-6434 or Mr. D. R. Hirzel at 373-4121.

\section{Approval of engineering reports, plans, and specifications and operating and maintenance manual - WAC 173-240}

Before construction or modification of those domestic or industrial wastewater facilities requiring Ecology wastewater discharge permits, engineering reports, plans, and specifications for the project must be submitted to and approved by Ecology. Operation and maintenance manuals must be submitted before construction is completed. 


\section{EVALUATION:}

An engineering report will be required for the modification of the septic system that services the 2736-ZB building. The septic system will be modified by blanking the lines leading from the septic tank to the drain field. The drain field is currently failed. The septic tank is pumped out on a weekly schedule. This system is also being proposed to handle any septic discharge from the mobile office that will be installed as part of Project W-460. Alternatives that will be evaluated for the septic system modification will be the tie-in to the regional septic system (Project L-281), permitting and use of a holding tank, and the installation of a new drain field. For more information contact Ms. P. K. Aardal at 373-6434 or Mr. D. R. Hirzel at $373-4121$.

\section{UIC Permit/Registration - WAC 173-218}

Authorization by Ecology of fluids injected through wells has been restricted to wells operational before February 29,1984. New discharges of uncontaminated storm water and groundwater return flow, unaltered except for temperature from a ground water heat pump used for heating or cooling, are the only discharges that are not prohibited. These discharges must be registered with Ecology before construction.

\section{EVALUATION:}

Project W-460 will not be creating any injection wells. The only discharge that will not be managed by engineering controls will be the rain water that is allowed to run off the mobile office that will be installed during this project.

\section{DOMESTIC WASTE WATER DISPOSAL}

\section{Septic system approvals/permits $(<14,500$ gpd design capacity $)$ - WAC 246-272}

Plans and specifications for construction of a new sanitary sewer system or modification of an existing system shall be submitted and approved by the DOH before construction or entering into a contract for construction. Once the installation is complete, a Professional Engineer registered in Washington State must certify that the installation has been installed according to plans and specifications approved by the DOH. In addition, an operation and maintenance manual must be submitted to the DOH.

Note: The DOH has taken the following position regarding modification or expansion of a drainfield located in the area of a known subsurface chemical hazard that could potentially cause the plume to harm groundwater: No 
modification or expansion will be allowed, consistent with regulations established for larger on-site sewage systems, preliminary report requirements (WAC 246-272-080).

\section{EVALUATION:}

The current septic system has a 750 gallon capacity. This system is pumped once a week. The drain field on this septic system has failed. The domestic waste water, if increased with the installation of a wet trailer, may have a high enough discharge to increase the frequency of pumping the septic tank or the installation of a new drain field. The modification of the septic system by blanking the tank from the drain field will require that an engineering report be submitted and approved the state of Washington.

\section{Septic System approvals/permits (>14,500 gpd design capacity) - WAC 173-216; WAC 173-240}

Septic systems with design capacities greater than 14,500 gpd are governed by State Waste Discharge Permits (WAC 173-216) and the engineering report, plan, and specification approval process described in WAC 173-240.

\section{EVALUATION:}

The capacity that is required will need to be reviewed in an engineering report. For more information contact Ms. P. K. Aardal at 373-6434 or Mr. D. R. Hirzel at 373-4121.

\section{Pretreatment Permit - 40 CFR 403}

New wastewater discharges to the City's sewage treatment plant may be required to submit permit applications to the City of Richland before discharging sewage, industrial waste, or other waste. Whether a permit application is needed depends on whether the activity is considered a Significant Industrial Discharge by the City or fits a national pretreatment category.

\section{EVALUATION:}

Not applicable to Project W-460.

\section{Operator Certification - WAC 173-230}


Every operator in responsible charge of a domestic wastewater treatment plant is required to be certified at a level equal to or higher than the classification rating of the treatment plant being operated. Septic systems are excluded from requiring certified operators.

\section{EVALUATION:}

Not applicable to project W-460.

\section{Discharge Standards and Effluent Limitations for Domestic Waste Water Facilities - WAC 173-221}

Effluent from domestic wastewater treatment facilities, except subsurface septic tank systems with capacities less than 14,500 gallons per day, must meet the discharge standards established in this regulation.

\section{EVALUATION:}

Should discharge to the septic system increase above 14,500 gallons per day the standards and limitations must be met. It is not anticipated that this discharge amount will be exceeded. For more information contact Ms. P. K. Aardal at 373-6434 or Mr. D. R. Hirzel at $373-4121$.

\section{SURFACE WASTE WATER DISPOSAL}

\section{NPDES Permit - 40 CFR 122}

Any discharge of pollutants to waters of the United States is required to have an NPDES permit before operation. The regulatory agency responsible for issuance of this permit is the EPA.

\section{EVALUATION:}

Project W-460 will not be discharging any pollutants to the waters of the United States. For more information contact Ms. P. K. Aardal at 373-6434 or Mr. D. R. Hirzel at 373-4121.

\section{Storm Water Discharge under EPA NPDES General Permit - 57 Federal Register 175, September 9, 1992}

The Hanford Site is covered under two storm water permits. Permit WA-R-00-000F covers storm water runoff for the Hanford Site as a whole. Permit WA-R-10-000F 
covers storm water runoff from construction projects. If there is a potential for storm water to reach the river from construction activities, an NOI for authorization under the EPA general permit and a SWPPP must be in place at least two days before discharge from new construction sites (those begun after October 1, 1992).

\section{EVALUATION:}

No storm water discharge from this project is expected to reach the river. For more information contact Mr. D. R. Hirzel at 373-4121.

\section{U.S. Department of the Army Permit - 33 CFR 325}

Discharging dredge and fill material into waters of the United States requires a permit from the U.S. Department of the Army, Corps of Engineers, before initiating the activity.

\section{EVALUATION:}

No dredging activities will be occurring with Project W-460. For more information contact Ms. P. K. Aardal at 373-6434.

\section{Section 10 Permit - 33 CFR 322}

Permits are required before the construction of structures and the performance of other activities in or adjacent to navigable waters. Certain activities are covered by nationwide permits rather than individual Section 10 permits. However, any work in an area designated as a "study river" for possible inclusion in the Wild and Scenic River System, such as the Hanford Reach, must obtain an individual Section 10 permit.

\section{EVALUATION:}

Not applicable to Project W-460.

\section{Nationwide Permits - 33 CFR 330}

Nationwide Permits are general permits issued by the USACE designed to regulate with little, if any, delay or documentation, certain waterway activities having minimal impacts. These permits are not applicable for projects within a Wild and Scenic River study area. 


\section{EVALUATION:}

Project W-460 will not affect any waterways. Therefore, this permit is not required. For more information contact Ms. P. K. Aardal at 373-6434.

\section{Hydraulic Projects Permit - WAC 220-110}

Any construction or other work that will change the natural flow of a river, including the addition of treated effluent waste water that will increase the natural flow, is required to obtain a hydraulic project approval from the State of Washington Department of Fisheries.

\section{EVALUATION:}

Not Applicable.

\section{Shoreline Development Permit - WAC 173-14 to -20}

A permit for developing the shoreline is required before construction for shorelines not federally owned, but under lease, easement, license, or other similar federal property rights short of fee ownership.

\section{EVALUATION:}

Not Applicable.

\section{Aquatic Lands Lease - WAC 332-30}

Aquatic land activities that interfere with the general public's use of state-owned tidelands, shorelands, and beds of navigable waters, require authorization before construction from the State of Washington Department of Natural Resources by way of agreement, lease, permit, or other instrument(s).

\section{EVALUATION:}

Not Applicable.

\section{Hanford Reach Study Act Notification - PL 100-605}


Proposed construction within one-quarter mile of the Columbia River shoreline inside the Hanford Reach Area is subject to consultation and coordination with the National Park Service.

\section{EVALUATION:}

Not applicable.

\section{Water Quality Modification Approval - WAC 173-201}

A permit, directive, or order, as appropriate, must be obtained from Ecology before undertaking an activity that will temporarily reduce water quality below the criteria and classifications established for the stream.

\section{EVALUATION:}

Project W-460 will not have any impact on water quality. For more information contact Ms.

P. K. Aardal at 373-6434.

\section{Ecology Certification of an EPA NPDES Permit - 40 CFR 121}

EPA may not issue an NPDES permit until a certification is granted or waived by Ecology. Ecology must certify that conditions necessary to ensure compliance with applicable federal and state water quality standards.

\section{EVALUATION:}

A NPDES permit is not expected to be required for this project. For more information contact Ms. P. K. Aardal at 373-6434 or Mr. D. R. Hirzel at 373-4121.

\section{Categorical Standards}

\section{Effluent Guideline and Standards - 40 CFR 405 to 471}

These regulations list industry categories associated with the NPDES permit program. The regulations prescribe effluent limitation guidelines for existing sources, standards of performance for new sources, and pretreatment standards for new and existing sources.

\section{EVALUATION:}


Not applicable. For more information contact Mr. D. R. Hirzel 373-4121.

\section{DRINKING WATER SUPPLY}

\section{Approval of Engineering Reports, Plans and Specifications - WAC 246-290}

Approval of engineering reports, plans, and specifications for a drinking water supply system is required before construction.

\section{EVALUATION:}

This project will not be installing any new drinking water system. For more information contact Mr. D. R. Hirzel at 373-4121.

\section{Drinking Water System Identification - WAC 246-290}

New drinking water systems must obtain an identification number from the $\mathrm{DOH}$ before operation.

\section{EVALUATION:}

This project will not be installing a new drinking water system. Therefore no identification is required. For more information contact Mr. D. R. Hirzel at 373-4121.

\section{Drinking Water System Operator Certification - WAC 246-292}

Operators in direct responsible charge of certain public water systems must be examined and certified for their competency on state requirements and standards before operating the system. Systems requiring certified operators include systems with 100 services at any one time; or systems serving 25 or more persons where the water is supplied from a stream, lake, or other surface water source and the systems are required by law to use a water filtration system.

\section{EVALUATION:}

No certification will be required since no operating system for drinking water will be installed. For more information contact Mr. D. R. Hirzel at 373-4121. 


\section{$\underline{\text { SOLID WASTE }}$}

\section{Solid Waste Handling Facility Permit - WAC 173-304}

Solid waste TSD sites or facilities (i.e., landfills, land spreading, piles, surface impoundments, and recycling facilities) must obtain approval from Ecology via the comprehensive solid waste plan, and a permit from the jurisdictional health department before construction.

\section{EVALUATION:}

Project W-460 will not be creating any solid waste handling facilities. Any waste generated from this project will be disposed of in accordance with federal, state and local regulations. For solid waste disposal question contact Mr. E. G. Backlund at 373-2708 or Mr. J. L. Brand at $373-2390$.

\section{DANGEROUS WASTE}

\section{Dangerous Waste Permit - WAC 173-303; 40 CFR 264, 265, 270}

Facilities that treat, store, or dispose of regulated dangerous waste must obtain the necessary dangerous waste permits. Whether a waste is a regulated dangerous waste must be determined in accordance with WAC 173-303-070 designation procedures. Existing Hanford Facility TSD units are obtaining permits in accordance with schedules and procedures identified in the Tri-Party Agreement. New Hanford Facility TSD units that are not identified in the Tri-Party Agreement will require development of a permitting plan to detail the strategies and schedules to be used for developing the necessary dangerous waste permits. This plan must be developed early in the project development phase. Strategies and schedules to be used for developing the necessary dangerous waste permits for new TSD units will need to be discussed with the appropriate regulatory agencies to gain their concurrence.

\section{EVALUATION:}

The scope of Project W-460 does not include construction or operation of a new TSD facility. Please contact Mr. G. G. Bergquist at 373-2709.

\section{UNDERGROUND STORAGE TANKS}

\section{UST Permit - WAC 173-360}

After July 1, 1991, no UST system, as defined in WAC 173-360, shall be operated without a valid permit from the regulatory agency. 


\section{EVALUATION:}

The scope of this project does not involve the installation/operation of any UST's. For more information contact Mr. G. G. Bergquist at 373-2709.

\section{$\underline{\text { ALL MEDIA }}$}

\section{Floodplain/Wetland Assessment - 10 CFR 1022}

A Floodplain/Wetland Assessment applies to all proposed floodplain/wetlands actions. A proposed action shall be designed to minimize potential harm to or within a floodplain. The assessment should be performed in conjunction with the NEPA process.

\section{EVALUATION:}

Project W-460 will not be occurring on oar affecting any floodplain or wetland designated areas. For more information contact Ms. P. K. Aardal at 373-6434.

\section{CRR - 36 CFR 800}

A CRR shall be performed before initiating any potential surface-disturbing activities onsite, or if any modifications are planned for any facility with the potential for inclusion on the National Register of Historic Places. The request form to perform this assessment is located on Jetforms.

\section{EVALUATION:}

A cultural resource review will need to be completed prior to beginning any construction activities. A historical review has been complete and a Memorandum of Agreement signed between U. S. Department of Energy, Washington State Historic Preservation Office and the Advisory council. For more information contact Ms. P. K. Aardal at 373-6434.

\section{Excavation Permit - 36 CFR 800}

An excavation permit is required before initiating any potential surface-disturbing onsite activities.

\section{EVALUATION:}


An excavation permit will be required for Project W-460. This will need to be obtained prior to any construction activities beginning. For approval and further information contact Ms. B. Nelson-Maki at 372-3058.

\section{Ecological Compliance Review - 10 CFR 1021; 50 CFR 402.6; DOE Order 5484.1}

A site survey should be performed to identify, if any: plant or animal species protected under the Endangered Species Act; candidates for such protection; species listed as threatened, endangered, candidate, sensitive, or monitored by the state of Washington; and species protected under the Migratory Bird Treaty Act. Also assessed is whether the planned activities have the potential to disturb any priority habitats and/or species identified in the survey. The request form to perform this review (along with a CRR) is WordPerfect macro GEF271. This review also fulfills the NEPA ecological/biological review requirement.

\section{EVALUATION:}

An ecological compliance review for Project W-460 will be required. The Plutonium Finishing Plant has one review performed for the complex on a yearly basis. To obtain a copy of the PFP complex ecological review contact Ms. P. K. Aardal at 373-6434.

\section{Preoperational Monitoring of Facilities, Sites, and Operations - DOE Order 5400.1}

Note: For more information see the Environmental Compliance Manual WHC-CM-7-5, Section 5.0, 5.4.2.1.g \& h, Section 8.0, 8.5.1.7, and Section $9.0,9.3 .1 .3$

An environmental study shall be conducted before startup of a site, facility, or process that has the potential for significant adverse environmental impact. This study should begin not less than one year and preferably two years before startup, so seasonal changes can be evaluated. This study precedes the conceptual design report and can include data acquired in the site selection process, excavation permit process, and NEPA/SEPA process. Mr. A. R. Johnson, 372-3056, of Near-Field Monitoring coordinates this work for WHC.

\section{EVALUATION:}

The scope of Project W-460 will not be starting a new process that has not been evaluated for environmental impacts before. For more information contact Ms. P. K. Aardal at 373-6434. 


\section{Radiation Protection Standards - DOE Order 5400.5}

This DOE Order establishes standards and requirements that must be followed to protect members of the public and environment against undue risk from radiation. The general environmental protection program requirements are established in DOE Order 5400.1. DOE Order 5400.1 requires that all DOE Sites prepare an environmental monitoring plan. DOE/RL 91-50, Environmental Monitoring Plan, includes DOE/EH-0173T, Environmental Regulatory Guide for Radiological Effluent Monitoring and Environmental Surveillance, which provides specific guidance regarding environmental monitoring activities.

\section{EVALUATION:}

Project W-460 will be performed in accordance with DOE Order 5400.5. For more information contact Mr. S. C. Snyder at 373-2564. 


\title{
APPENDIX G
}

\author{
Project W-460 \\ BA/BO PROFILE
}


Table G-1 - W-460BA/BO Profile

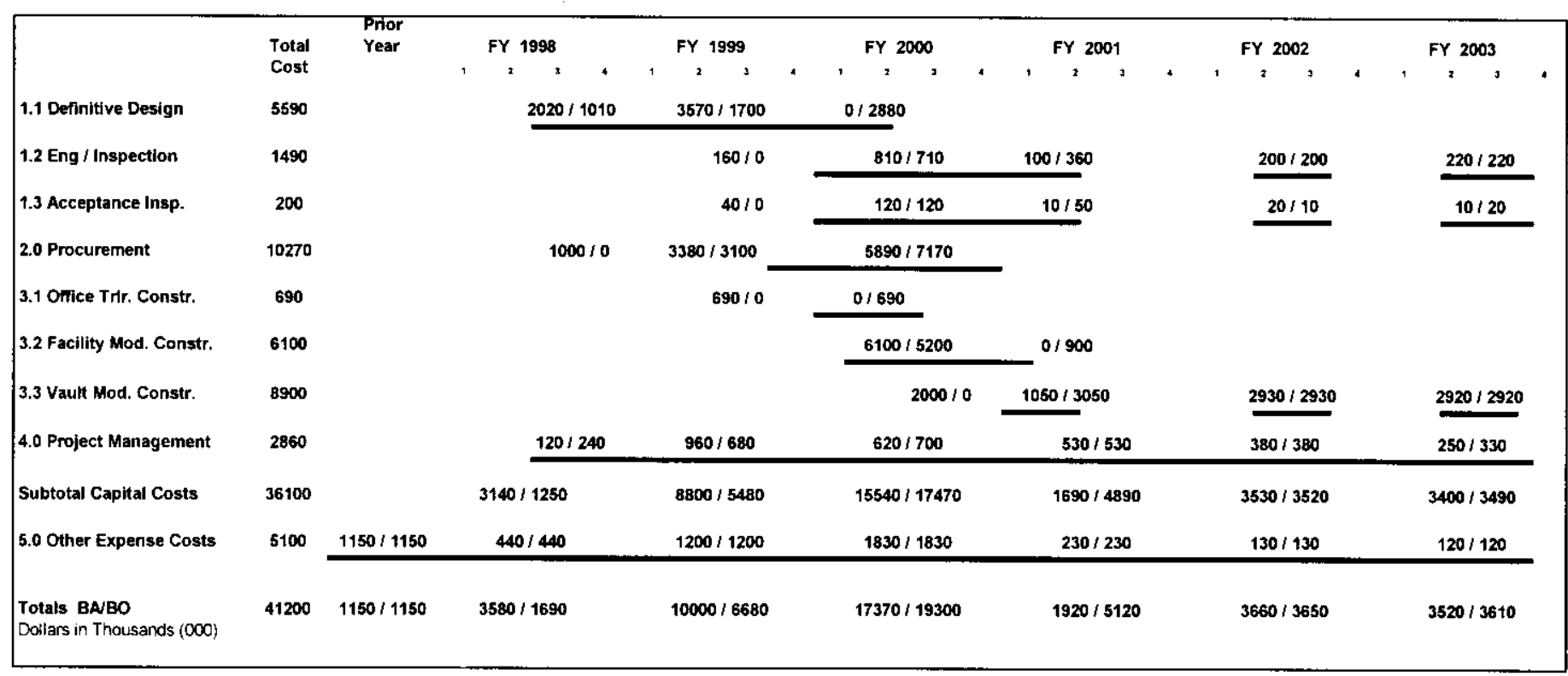




\section{DISTRIBUTION SHEET}

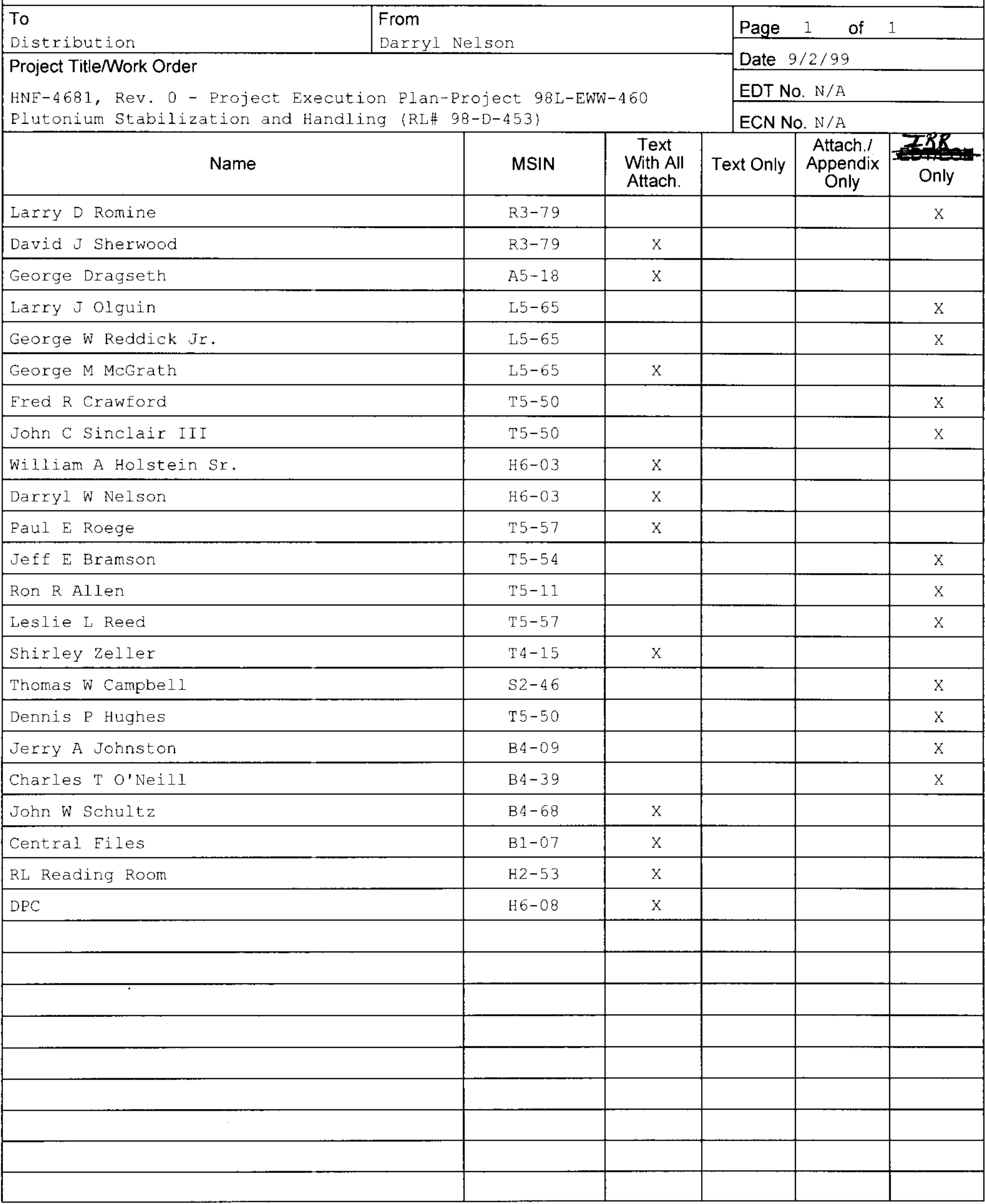

